Prepared in cooperation with the Honolulu Board of Water Supply

\title{
Numerical Simulation of Flow in Deep Open Boreholes in a Coastal Freshwater Lens, Pearl Harbor Aquifer, O‘ahu, Hawai'i
}



Scientific Investigations Report 2012-5009 
Cross section of simulated solute concentration in percent seawater salinity near a deep monitor well (dotted line) in a homogeneous coastal aquifer for the model scenario with additional withdrawal of 16.7 million gallons per day from a well 100 feet away from the deep monitor well (white bar), using the theoretical well hydraulic conductivity for turbulent flow. 


\section{Numerical Simulation of Flow in Deep Open Boreholes in a Coastal Freshwater Lens, Pearl Harbor Aquifer, O‘ahu, Hawai' $i$}

Prepared in cooperation with the Honolulu Board of Water Supply

By Kolja Rotzoll

Scientific Investigations Report 2012-5009 


\section{U.S. Department of the Interior \\ KEN SALAZAR, Secretary \\ U.S. Geological Survey \\ Marcia K. McNutt, Director}

U.S. Geological Survey, Reston, Virginia 2012

This report and any updates to it are available online at:

http://pubs.usgs.gov/sir/2012/5009/

For more information on the USGS - the Federal source for science about the Earth, its natural and living resources, natural hazards, and the environment, visit http://www.usgs.gov or call 1-888-ASK-USGS

For an overview of USGS information products, including maps, imagery, and publications, visit http://www.usgs.gov/pubprod

To order this and other USGS information products, visit http://store.usgs.gov

Any use of trade, product, or firm names is for descriptive purposes only and does not imply endorsement by the U.S. Government.

Although this report is in the public domain, permission must be secured from the individual copyright owners to reproduce any copyrighted material contained within this report.

Suggested citation:

Rotzoll, K., 2012, Numerical simulation of flow in deep open boreholes in a coastal freshwater lens, Pearl Harbor Aquifer, O‘ahu, Hawai'i: U.S. Geological Survey

Scientific Investigations Report 2012-5009, 39 p. 


\section{Contents}

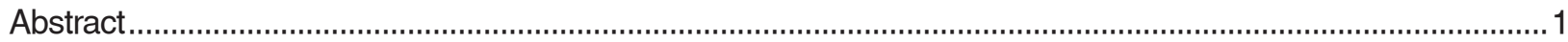





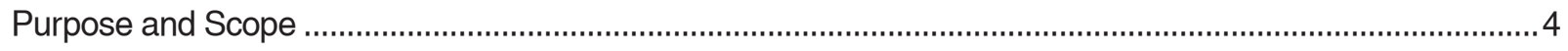

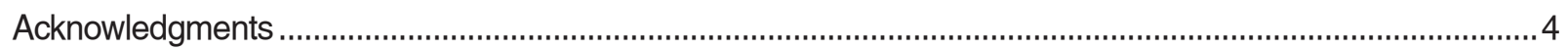

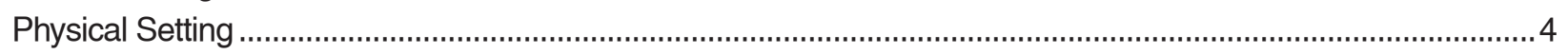



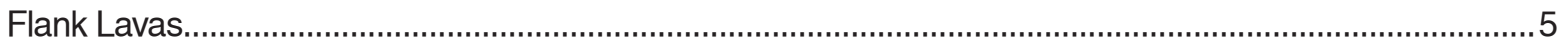

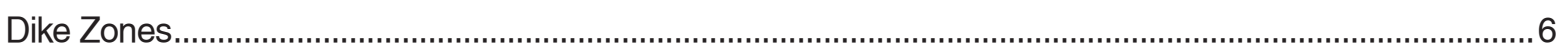













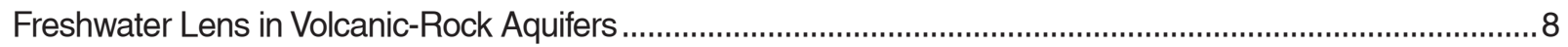

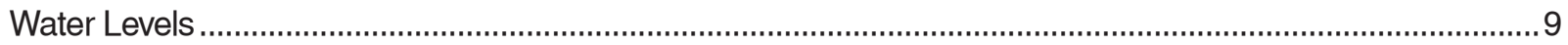

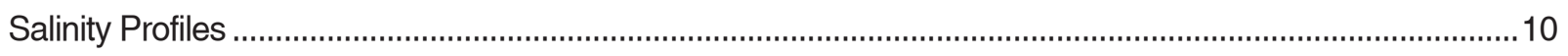



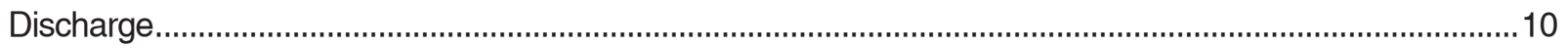



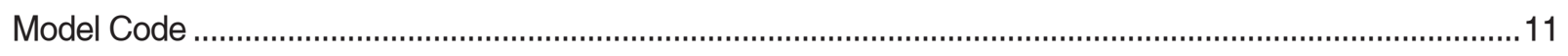

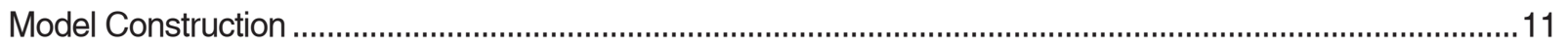

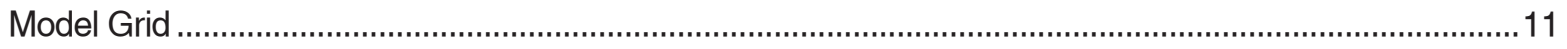

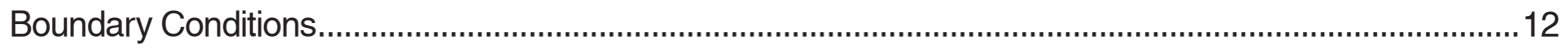

Specified-Head and Specified-Concentration Boundaries............................................................... 13

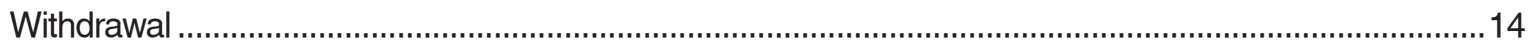

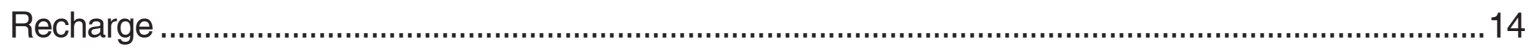

Spring Discharge



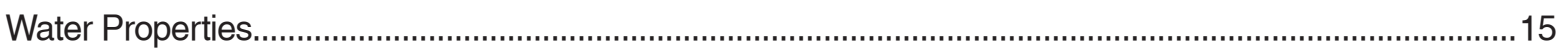

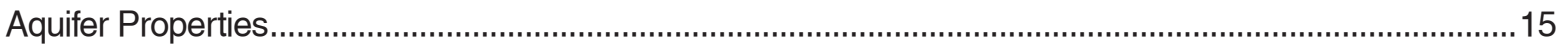



Evaluation of Simulated "Steady-State" Initial Condition ........................................................................... 17

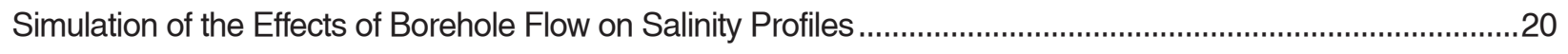



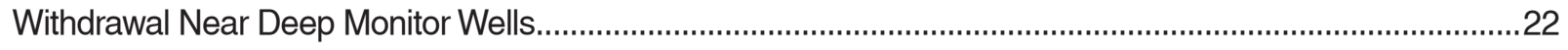

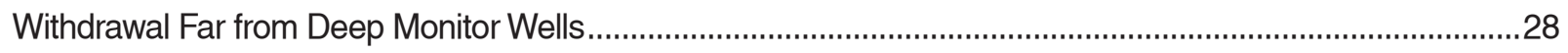

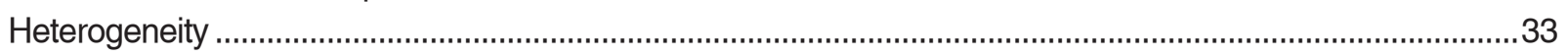

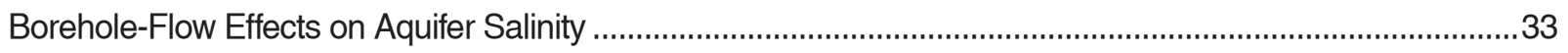



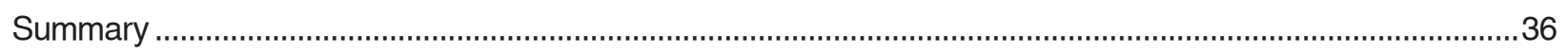






\section{Figures}

1. Map of deep monitor wells (DMWs) in southern O'ahu, State of Hawai'i aquifer-sector and aquifer-system boundaries, and salinity profiles of selected wells.

2. Hypothetical example showing borehole flow and how the measured salinity profile does not accurately reflect water quality in the aquifer.

3. Generalized land use (Hawaii Gap Analysis Program, 2005) and State of Hawai'i aquifer-management systems in Pearl Harbor, O'ahu Hawai'i.....

4. Map of groundwater types and general geologic features on O'ahu, Hawaił

5. Generalized diagram of groundwater occurrence and movement (arrows) in the Pearl Harbor aquifer, O’ahu, Hawai'i.

6. Average of measured groundwater levels from October 31, 2002 and May 15, 2003 in selected wells in the Pearl Harbor area, O'ahu, Hawai'i.

7. Location of two-dimensional vertical cross section, extent of three-dimensional model boundaries in plan view, simulated boreholes, and measured midpoint of the transition zone in southern O'ahu, Hawai'i.

8. Cross section showing surface recharge distirbution, vertical grid discretization, contact between caprock and flank lava, boundary conditions, and specified (blue) and model calculated (red) net water flux in and out of the model in million gallons per day per mile (Mgal/d/mi)

9. Ratio of area of Pearl Harbor water bodies perpendicular to model cross section to the total area of the Waipahu-Waiawa and Waimalu aquifer systems, O'ahu, Hawai'i

10. Sensitivity analysis of well hydraulic conductivity

11. Cross section of simulated hydraulic head and solute concentration for the initial condition

12. Simulated "steady-state" water levels compared to measured water levels in selected wells in the Pearl Harbor area, O'ahu, Hawai'i.

13. Simulated "steady-state" and measured salinity in selected deep monitor wells (DMWs) in the Pearl Harbor area, O'ahu, Hawai'i

14. Compared features of simulated aquifer-and borehole salinity.

15. Model results of scenario 1a.-Regional aquifer flow with no additional withdrawals using the effective well hydraulic conductivity $\left(K_{\text {well }}\right)$ for deep monitor wells (DMWs).....

16. Cross sections of simulated solute concentration in percent seawater salinity near DMW-1 (dotted line) in a homogeneous aquifer for selected model scenarios

17. Model results of scenario $1 \mathrm{~b}$.- - Regional aquifer flow with no additional withdrawals using the theoretical well hydraulic conductivity for turbulent flow $\left(K_{t u r}\right)$ for deep monitor wells (DMWs)

18. Model results of scenario 2a.-Additional withdrawal of 4.3 million gallons per day from a well 100 feet away from DMW-1 using the effective well hydraulic conductivity $\left(K_{\text {well }}\right)$ for deep monitor wells (DMWs). 
19. Model results of scenario $2 \mathrm{~b}$.-Additional withdrawal of 4.3 million gallons per day from a well 100 feet away from DMW-1 using the theoretical well hydraulic conductivity for turbulent flow $\left(K_{\text {tur }}\right)$ for deep monitor wells (DMWs).

20. Model results of scenario 3a.-Additional withdrawal of 16.7 million gallons per day from a well 100 feet away from DMW-1 using the effective well hydraulic conductivity $\left(K_{\text {well }}\right)$ for deep monitor wells (DMWs) ...27

21. Model results of scenario $3 b$.-Additional withdrawal of 16.7 million gallons per day from a well 100 feet away from DMW-1 using the theoretical well hydraulic conductivity for turbulent flow $\left(K_{\text {tur }}\right)$ for deep monitor wells (DMWs)...

22. Model results of scenario 4.-Additional withdrawal of 4.3 million gallons per day from a well 3,000 feet away from DMW-1 using the effective well hydraulic conductivity $\left(K_{\text {well }}\right)$ for deep monitor wells (DMWs).

23. Model results of scenario 5.-Additional withdrawal of 16.7 million gallons per day from a well 3,000 feet away from DMW-1 using the effective well hydraulic conductivity $\left(K_{\text {well }}\right)$ for deep monitor wells (DMWs).

24. Model results of scenario 6.-Additional withdrawal of 16.7 million gallons per day from a shaft 3,000 feet away from DMW-1 using the effective well hydraulic conductivity $\left(K_{\text {well }}\right)$ for deep monitor wells (DMWs).

25. Hydraulic conductivity distribution for the heterogeneous basalt aquifer used in scenarios 7 and 8 .

26. Model results of scenarios 7 and 8.-Additional withdrawal of 3.8 and 16.7 million gallons per day from a well 100 feet away from DMW-1 using the effective well hydraulic conductivity $\left(K_{\text {well }}\right)$ for deep monitor wells (DMWs) in a heterogeneous aquifer..

27. Average salinity difference between simulations with and without deep monitor well (DMW) relative to distance from DMW-1.

\section{Tables}

1. Aquifer- and well-property values used in the construction of the borehole-flow model of the Pearl Harbor area, O'ahu, Hawai'i.

2. Summary of scenarios tested in the borehole-flow model of the Pearl Harbor area, O'ahu, Hawai'i.

3 Summary of the borehole-flow model results in the form of displacements of the 2 and 50 percent salinity depths in the borehole relative to the aquifer, and average salinity difference between aquifer and borehole from the midpoint upwards.

4. Summary of the borehole-flow model results in the form of minimum and maximum borehole-flow velocities 


\section{Conversion Factors}

Inch/Pound to SI

\begin{tabular}{lcl}
\hline \multicolumn{1}{c}{ Multiply } & By & \multicolumn{1}{c}{ To obtain } \\
\hline inch (in.) & Length & \\
inch (in.) & 2.54 & centimeter $(\mathrm{cm})$ \\
foot (ft) & 25.4 & millimeter $(\mathrm{mm})$ \\
mile (mi) & 0.3048 & meter $(\mathrm{m})$ \\
\hline & 1.609 & kilometer $(\mathrm{km})$ \\
\hline gallon (gal) & Volume & \\
gallon (gal) & 3.785 & liter $(\mathrm{L})$ \\
gallon (gal) & 0.003785 & cubic meter $\left(\mathrm{m}^{3}\right)$ \\
million gallons (Mgal) & 3.785 & cubic decimeter $\left(\mathrm{dm}^{3}\right)$ \\
\hline & 3,785 & cubic meter $\left(\mathrm{m}^{3}\right)$ \\
\hline foot per minute (ft/min) & Flow rate & \\
foot per day (ft/d) & 0.3048 & meter per minute $\left(\mathrm{m} / \mathrm{min}^{3}\right)$ \\
gallon per day (gal/d) & 0.3048 & meter per day $(\mathrm{m} / \mathrm{d})$ \\
million gallons per day (Mgal/d) & 0.04381 & cubic meter per second $\left(\mathrm{m}^{3} / \mathrm{s}\right)$ \\
\hline
\end{tabular}

Hydraulic conductivity

foot per day $(\mathrm{ft} / \mathrm{d}) \quad 0.3048 \quad$ meter per day $(\mathrm{m} / \mathrm{d})$

\section{Hydraulic gradient}

\begin{tabular}{l}
\hline foot per mile $(\mathrm{ft} / \mathrm{mi})$ \\
\hline Temperature in degrees Celsius $\left({ }^{\circ} \mathrm{C}\right)$ may be converted to degrees Fahrenheit $\left({ }^{\circ} \mathrm{F}\right)$ as follows: ${ }^{\circ} \mathrm{F}=\left(1.8 \times{ }^{\circ} \mathrm{C}\right)+32$ \\
Horizontal coordinate information is referenced to the North American Datum of $1983(\mathrm{NAD} 83)$. \\
Vertical coordinate information is referenced in feet relative to mean sea level. Altitude, as used in this report, \\
refers to distance above the vertical datum. \\
Specific conductance is given either in microsiemens per centimeter at 25 degrees Celsius $(\mu \mathrm{S} / \mathrm{cm})$ or \\
millisiemens per centimeter at 25 degrees Celsius $(\mathrm{mS} / \mathrm{cm})$. \\
Concentrations of chemical constituents in water are given in milligrams per liter $(\mathrm{mg} / \mathrm{L})$.
\end{tabular}




\title{
Numerical Simulation of Flow in Deep Open Boreholes in a Coastal Freshwater Lens, Pearl Harbor Aquifer, O’ahu, Hawai'i
}

\author{
By Kolja Rotzoll ${ }^{1}$
}

\section{Abstract}

The Pearl Harbor aquifer in southern $\mathrm{O}^{\prime}$ ahu is one of the most important sources of freshwater in Hawai 'i. A thick freshwater lens overlays brackish and saltwater in this coastal aquifer. Salinity profiles collected from uncased deep monitor wells (DMWs) commonly are used to monitor freshwater-lens thickness. However, vertical flow in DMWs can cause the measured salinity to differ from salinity in the adjacent aquifer or in an aquifer without a DWM. Substantial borehole flow and displacement of salinity in DMWs over several hundred feet have been observed in the Pearl Harbor aquifer. The objective of this study was to evaluate the effects of borehole flow on measured salinity profiles from DMWs. A numerical modeling approach incorporated aquifer hydraulic characteristics and recharge and withdrawal rates representative of the Pearl Harbor aquifer. Borehole flow caused by vertical hydraulic gradients associated with both the natural regional flow system and groundwater withdrawals was simulated.

Model results indicate that, with all other factors being equal, greater withdrawal rates, closer withdrawal locations, or higher hydraulic conductivities of the well cause greater borehole flow and displacement of salinity in the well. Borehole flow caused by the natural groundwater-flow system is five orders of magnitude greater than vertical flow in a homogeneous aquifer, and boreholeflow directions are consistent with the regional flow system: downward flow in inland recharge areas and upward flow in coastal discharge areas. Displacement of salinity inside the DMWs associated with the regional groundwater-flow system ranges from less than 1 to $220 \mathrm{ft}$, depending on the location and assumed hydraulic conductivity of the well. For example, upward displacements of the 2 percent and 50 percent salinity depths in a well in the coastal discharge part of the flow system are 17 and $4.4 \mathrm{ft}$, respectively, and the average salinity difference between aquifer and borehole is 0.65 percent seawater salinity.

Groundwater withdrawals and drawdowns generally occur at shallow depths in the freshwater system with respect to the depth of the DMW and cause upward flow in the DMW. Simulated groundwater withdrawal of 4.3 million gallons per day that is $100 \mathrm{ft}$ from a DMW causes thirty times more borehole flow than borehole flow that is induced by the regional flow field alone. The displacement of the 2 percent borehole salinity depth increases from 17 to $33 \mathrm{ft}$, and the average salinity difference between aquifer and borehole

\footnotetext{
${ }^{1}$ University of Hawai' $i$ at Mānoa, Water Resources Research Center
}

is 0.85 percent seawater salinity. Peak borehole flow caused by local groundwater withdrawal near DMWs is directly proportional to the pumping rate in the nearby production well. Increasing groundwater withdrawal to 16.7 million gallons per day increases upward displacement of the 50 percent salinity depth (midpoint of the transition zone) from 4.6 to $77 \mathrm{ft}$, and the average salinity difference between aquifer and borehole is 1.4 percent seawater salinity.

Simulated groundwater withdrawal that is $3,000 \mathrm{ft}$ away from DMWs causes less borehole flow and salinity displacements than nearby withdrawal. Simulated effects of groundwater withdrawal from a horizontal shaft and withdrawal from a vertical well in a homogeneous aquifer were similar. Generally, the 50 percent salinity depths are less affected by borehole flow than the 2 percent salinity depths. Hence, measured salinity profiles are useful for calibration of regional numerical models despite borehole-flow effects. Commonly, a 1 percent error in salinity is acceptable in numerical modeling studies.

Incorporation of heterogeneity in the model is necessary to simulate long vertical steps observed in salinity profiles in southern $\mathrm{O}^{\prime}$ ahu. A thick zone of low aquifer hydraulic conductivity limits exchange of water between aquifer and well and creates a long vertical step in the salinity profile. A heterogeneous basalt-aquifer scenario simulates observed vertical salinity steps and borehole flow that is consistent with measured borehole flow from DMWs in southern $\mathrm{O}^{`} \mathrm{ahu}$. However, inclusion of local-scale heterogeneities in regional models generally is not warranted.

\section{Introduction}

\section{Background}

Groundwater is a valuable but limited resource on the islands of Hawai ' $\mathrm{i}$, as it provides almost all drinking water and more than half of freshwater for other uses. Groundwater predominantly occurs in flank lavas as freshwater-lens systems and high-level water in dike-impounded systems (Gingerich and Oki, 2000). One of the most heavily used aquifer systems in the State of Hawai ' $i$ is in the Pearl Harbor area of southern $\mathrm{O}^{\prime}$ ahu, producing more than 200 million gallons per day (Mgal/d) during the 1970s when sugarcane was actively cultivated and, more recently, about $100 \mathrm{Mgal} / \mathrm{d}$ during the past $10 \mathrm{yr}$ 
(Oki, 2005; Rotzoll and others, 2010). The availability of coastal groundwater resources is commonly assessed through repeated salinity profiling of wells that penetrate through the freshwater lens into underlying saltwater. In the Pearl Harbor area, 14 deep monitor wells (DMWs) penetrate through the transition zone into the saltwater (fig. 1). The boreholes are uncased (open) from depths between a few tens of feet below mean sea level to the well bottom, at altitudes ranging from -955 to $-1,377 \mathrm{ft}$ relative to mean sea level.

The thickness of freshwater lenses in Hawai ' $\mathrm{i}$ is controlled geologically by the hydraulic properties of the volcanic rocks that form the aquifer and sedimentary deposits that form the confining units, and dynamically by the amount of recharge to (precipitation and irrigation) and discharge from (groundwater withdrawals and outflow to the ocean) the lens. The Honolulu Board of Water Supply (HBWS), the Commission on Water Resource Management (CWRM), and the U.S. Geological Survey (USGS) collect salinity profiles to monitor changes in freshwater-lens thickness. These profiles are fluid electrical conductivity measurements that have been normalized to $25^{\circ} \mathrm{C}$ and typically are assumed to reflect groundwater salinity (Rotzoll, 2010).

Freshwater/saltwater interface locations predicted from measured water levels and the Ghyben-Herzberg principle

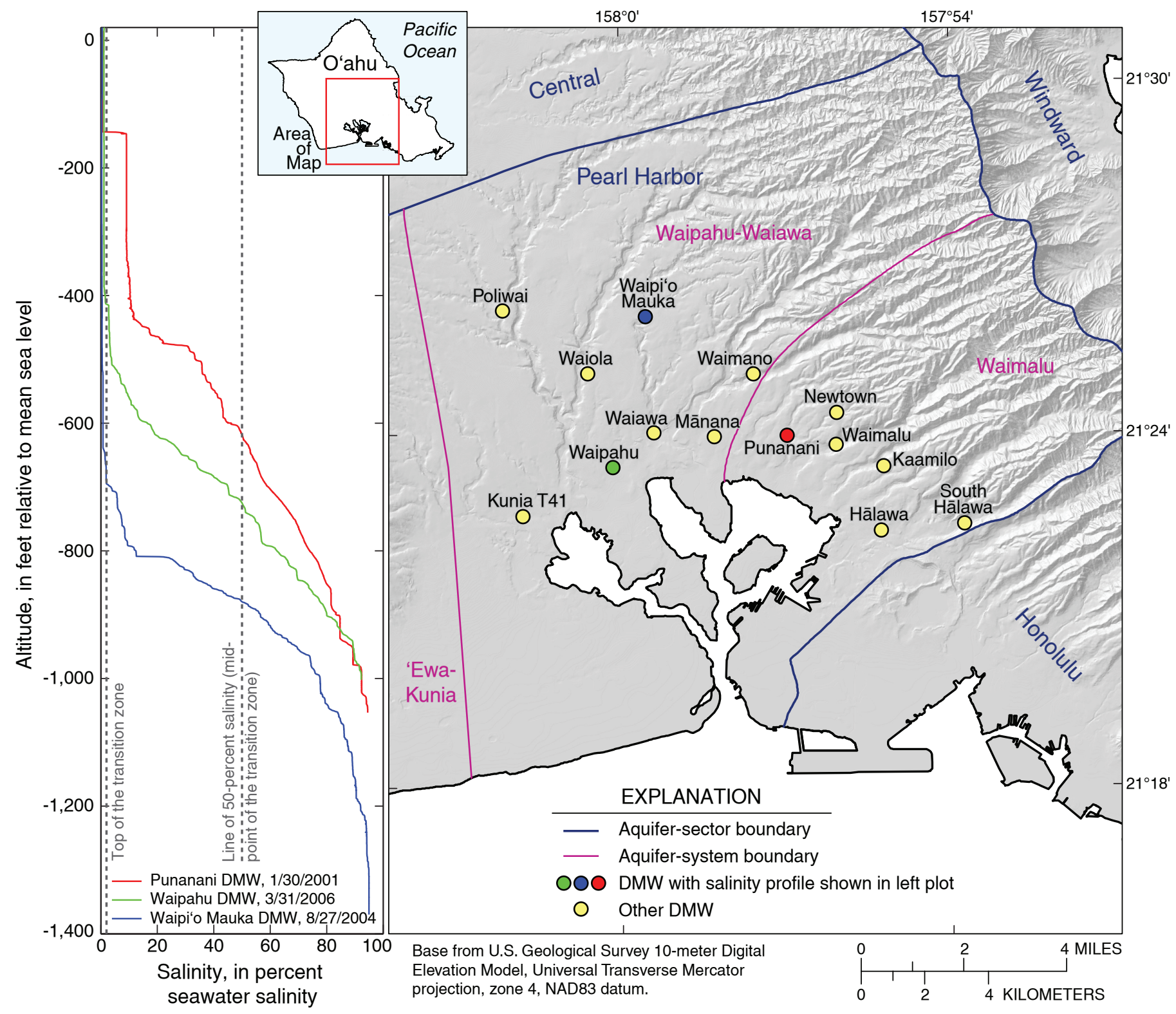

Figure 1. Map of deep monitor wells (DMWs) in southern O'ahu, State of Hawai'i aquifer-sector and aquifer-system boundaries, and salinity profiles of selected wells. 
differ from measured locations of 50 percent saltwater concentration (midpoints) within the transition zone between freshwater and saltwater by more than $300 \mathrm{ft}$ in some wells. Therefore, water levels may not be a reliable indicator of the amount of freshwater in a coastal aquifer (Rotzoll and others, 2010). Because the freshwater-lens system is dynamic, monitoring the movement of the top (depth where salinity is approximately 2 percent saltwater) and midpoint (depth where salinity is 50 percent saltwater) of the transition zone between freshwater and saltwater are more appropriate. However, monitoring the top of the transition zone is problematic in the Pearl Harbor area, because nearby groundwater withdrawals cause upward flow in the upper part of many DMWs (Rotzoll, 2010). Thus, the midpoint depth is a better indicator for freshwater thickness. Most measured midpoints from DMWs in the Pearl Harbor area have risen at a rate of $2-3 \mathrm{ft} / \mathrm{yr}$ over the past $40 \mathrm{yr}$, indicating a shrinking lens (Rotzoll and others, 2010).

Vertical salinity profiles also are important for calibration of numerical groundwater models that simulate densitydependent groundwater flow and transport in coastal aquifers (Voss and Souza, 1987; Oki and others, 1998). These models are useful tools for managing groundwater resources because they provide insights into groundwater availability under different recharge and withdrawal scenarios (Oki, 2005;
Gingerich, 2008). The CWRM uses the Robust Analytical Model (Mink, 1981) and the Robust Analytical Model 2 (Liu, 2007) for estimating the amount of groundwater that can be withdrawn from aquifer systems in the state. The Robust Analytical Model 2 incorporates information from salinity profiles to estimate sustainable withdrawal rates.

Fresh groundwater resources are monitored and managed with salinity-profile data. However, vertical flow in DMWs causes the measured salinity to differ from salinity in the adjacent aquifer. Upward or downward flow may displace the top and midpoint of the transition zone in the borehole with respect to the aquifer. Substantial borehole flow has been observed in DMWs in the Honolulu (Paillet and others, 2002) and Pearl Harbor areas (Paillet and Hess, 1995). In the eastern Pearl Harbor area, borehole flow causes the measured top-oftransition-zone depth to appear several hundred feet shallower than in the aquifer, which may lead to an underestimation of the freshwater-lens thickness (Rotzoll, 2010).

Many salinity profiles measured in the eastern part of the Pearl Harbor area and the Honolulu area have uniform salinities over hundreds of feet and sharp salinity changes of more than 5 percent over less than $5 \mathrm{ft}$ in some cases (Rotzoll, 2010). These characteristic features of a salinity profile are indicative of flow in the borehole and will be referred to as "steps" herein. The steps consist of a vertical part over

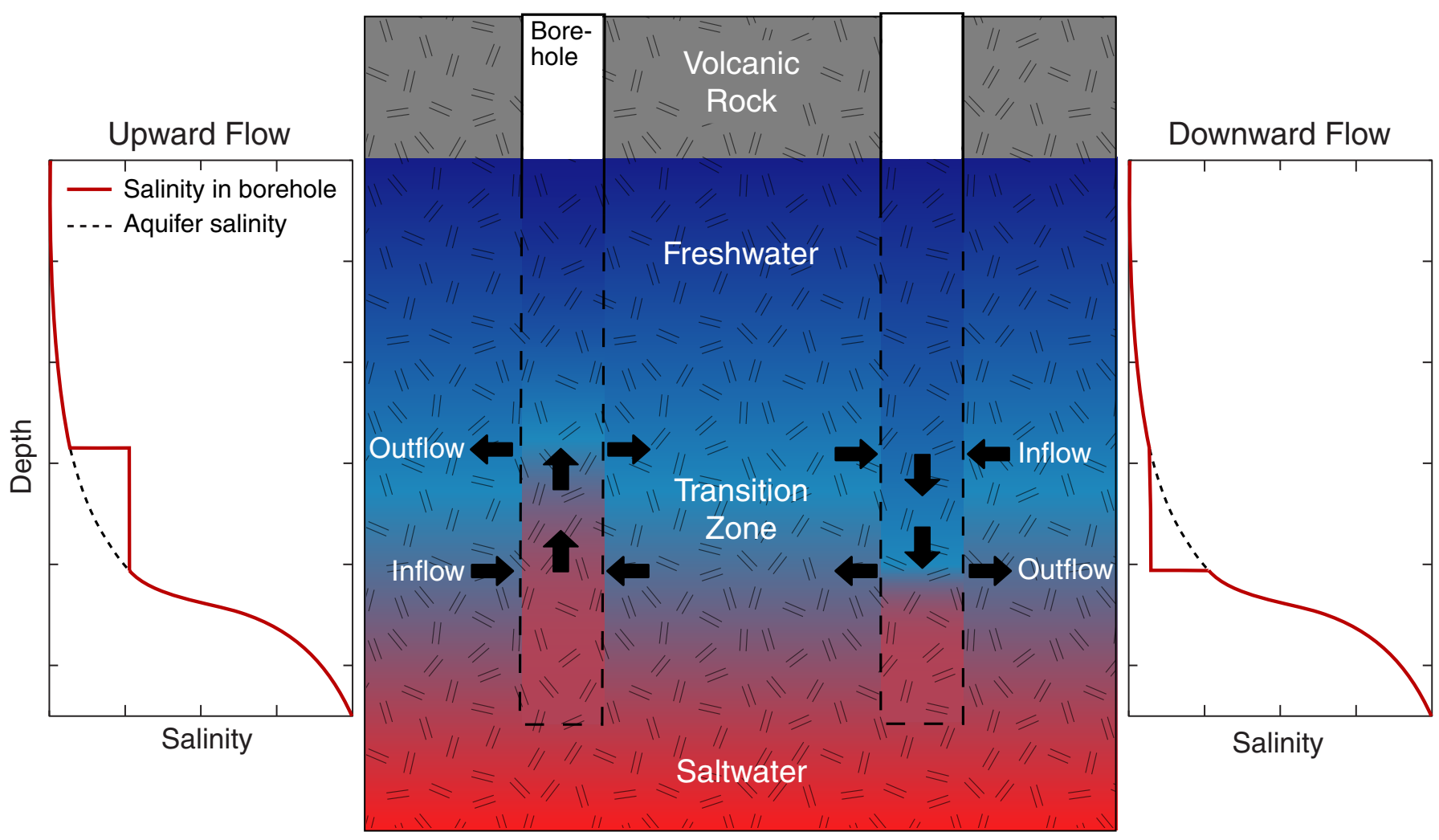

Figure 2. Hypothetical example showing borehole flow and how the measured salinity profile does not accurately reflect water quality in the aquifer. 
which the salinity in the borehole is uniform and borehole flow occurs, and a horizontal part that indicates the depth of outflow of water from the borehole to the aquifer (fig. 2).

Long vertical steps in salinity profiles are indicators of borehole flow. Electromagnetic or impeller flowmeters can measure the amount of flow through the well, although their use is problematic in Hawai ' $\mathrm{i}$. The uncased boreholes are uneven and the potential for measuring equipment to become trapped in the well is high. Nested piezometers, screened at short depth intervals, provide a better way to determine aquifer salinity and verticalhead gradients with depth. However, piezometers are expensive to install through drilling or retrofitting of existing DMWs, and piezometers may provide only limited vertical resolution of salinity in the aquifer.

Numerical modeling offers a relatively inexpensive approach to evaluate the effects of borehole flow on salinity profiles. Several authors have numerically modeled preferential groundwater flow and transport through monitor wells (Reilly and others, 1989; Lacombe and others, 1995; Elci and others, 2001, 2003; Konikow and Hornberger, 2006;

Zinn and Konikow, 2007). Chen and Jiao (1999) demonstrated a numerical-modeling approach to simulate nonlaminar flow in the wellbore and Halford (2000) simulated measurements of borehole flowmeters. Modeling density-dependent flow through monitor wells in a coastal aquifer with tidal influence showed substantial borehole flow and displacement of salinity within the monitor well (Shalev and others, 2009). Tidal effects on water levels and displacement of salinity have been assessed within one DMW in the Honolulu area and were found to be less than $1 \mathrm{ft}$ (Rotzoll, 2010), likely because of the presence of low-permeability coastal sediments. Therefore, tidal effects are not considered in this study.

\section{Purpose and Scope}

The purpose of this report is to evaluate whether measured vertical salinity profiles from DMWs in a coastal freshwater lens in Hawai 'i are representative of conditions in the adjacent aquifer. A numerical modeling approach, incorporating aquifer hydraulic characteristics and recharge rates representative of the Pearl Harbor aquifer, was used to simulate borehole flow caused by vertical hydraulic gradients associated with the natural regional groundwater-flow system and local groundwater withdrawals. The numerical model is capable of simulating density-dependent flow and transport and was calibrated using existing data. Aquifer heterogeneity, represented in the model as layers of contrasting permeability, was incorporated in some model scenarios. Model results were used to estimate the magnitude of differences between vertical salinity profiles in DMWs and the aquifer in areas of downward, horizontal, and upward flow within the regional flow system-for cases with and without nearby pumped wells. These insights are relevant for management and predictive modeling purposes. However, the results of the simulation work represent only general concepts and quantitative relations and are not intended to specifically simulate actual conditions on $\mathrm{O}^{`} \mathrm{ahu}$.

\section{Acknowledgments}

This study was funded through a cooperative agreement between the HBWS and the USGS. The author is grateful to Glenn Oyama and Darrell Wong of the HBWS for access to specific-conductance profiles. Constructive comments from Delwyn Oki, Keith Halford, Keith Prince, Clifford Voss, Richard Winston, Christian Langevin, and many others from the USGS Pacific Islands Water Science Center helped improve the report.

\section{Physical Setting}

$\mathrm{O}^{\prime}$ ahu is the third largest island in the State of Hawai' $\mathrm{i}$ located between long $158^{\circ} 17^{\prime} \mathrm{W}$. and $157^{\circ} 39^{\prime} \mathrm{W}$. and between lat $21^{\circ} 15^{\prime} \mathrm{N}$. and $21^{\circ} 42^{\prime} \mathrm{N}$. The eroded remnants of the Wai 'anae Volcano and Ko 'olau Volcano form two mountain ranges that reach maximum altitudes of 4,025 and 3,105 ft, respectively. Other topographic features are the Schofield Plateau, a saddle that connects both mountain ranges, and the coastal plain that covers most of O'ahu's southern coastal area. The study area is located in southern O'ahu and includes parts of the Pearl Harbor aquifer, namely the Waipahu-Waiawa and Waimalu aquifer-management systems designated by the CWRM (fig. 3). It is bounded in the west by the Wai'anae confining unit, in the east by the Red Hill Ridge, in the north by the Schofield Plateau and in the south by the Pacific Ocean. The CWRM management areas do not necessarily coincide with aquifer boundaries or hydrogeologic boundaries used in the numerical groundwater model in this study.

The study area includes steep interior mountains to a broad flat coastal plain. Topography of $\mathrm{O}^{\text {' }}$ ahu affects the local climate, which is characterized by mild and uniform temperatures, cool and persistent northeasterly trade winds, and seasonally and spatially variable rainfall. Maximum rainfall occurs at high altitudes and along the mountain flanks that are exposed to the northeasterly trade winds. Rainfall generally decreases from the mountains towards the coast. Dry leeward coastal areas occasionally receive heavy rainfall from storm systems passing from southerly directions. Mean annual rainfall in the Pearl Harbor study area ranges from 160 in. inland to less than 20 in. at the coast (Giambelluca and others, 1986).

The most densely populated areas, and therefore the

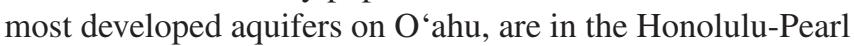
Harbor area (Hawaii Gap Analysis Program, 2005). During the 1970s when sugarcane was cultivated, more than $200 \mathrm{Mgal} / \mathrm{d}$ were withdrawn from the Pearl Harbor aquifer and, more recently, about $100 \mathrm{Mgal} / \mathrm{d}$ were withdrawn during the past 10 yr (Oki, 2005; Rotzoll and others, 2010). Water management in southern $\mathrm{O}^{\prime}$ ahu is facing new challenges, 
because water demands are increasing as small-scale diversified agriculture and rapidly expanding urban developments replace large-scale sugarcane and pineapple plantations and because the effects of climate change on future recharge of the groundwater resource are uncertain.

\section{Geology}

The geology of O'ahu was described in detail by Stearns and Vaksvik (1935), Stearns (1939), and Macdonald and others (1983). The Islands of Hawai' $i$ were formed by eruption of thousands of lava flows as the Pacific Plate of the Earth's lithosphere moved over the Hawaiian hotspot. O'ahu consists of two shield volcanoes that extruded primarily thin basaltic lava flows from central calderas and fissures along rift zones between 3.2 and 2.9 million years ago (Wai'anae Volcano, west of the study area) and between 2.6 and 1.8 million years ago (Ko'olau Volcano, east of the study area) (Doell and Dalrymple, 1973).

\section{Flank Lavas}

The volcanic rocks in the study area mainly consist of thin-bedded, shield-stage tholeiitic flows of the Ko'olau Volcano overlying the shield-stage tholeiitic flows of the Wai'anae Volcano. The lava flows that build the flanks of the volcanoes are ' $a$ ' $\bar{a}$ (massive lava cores interbedded with rubbly clinker layers) and pāhoehoe (ropy, smooth lava flows). Typical sequences of lava

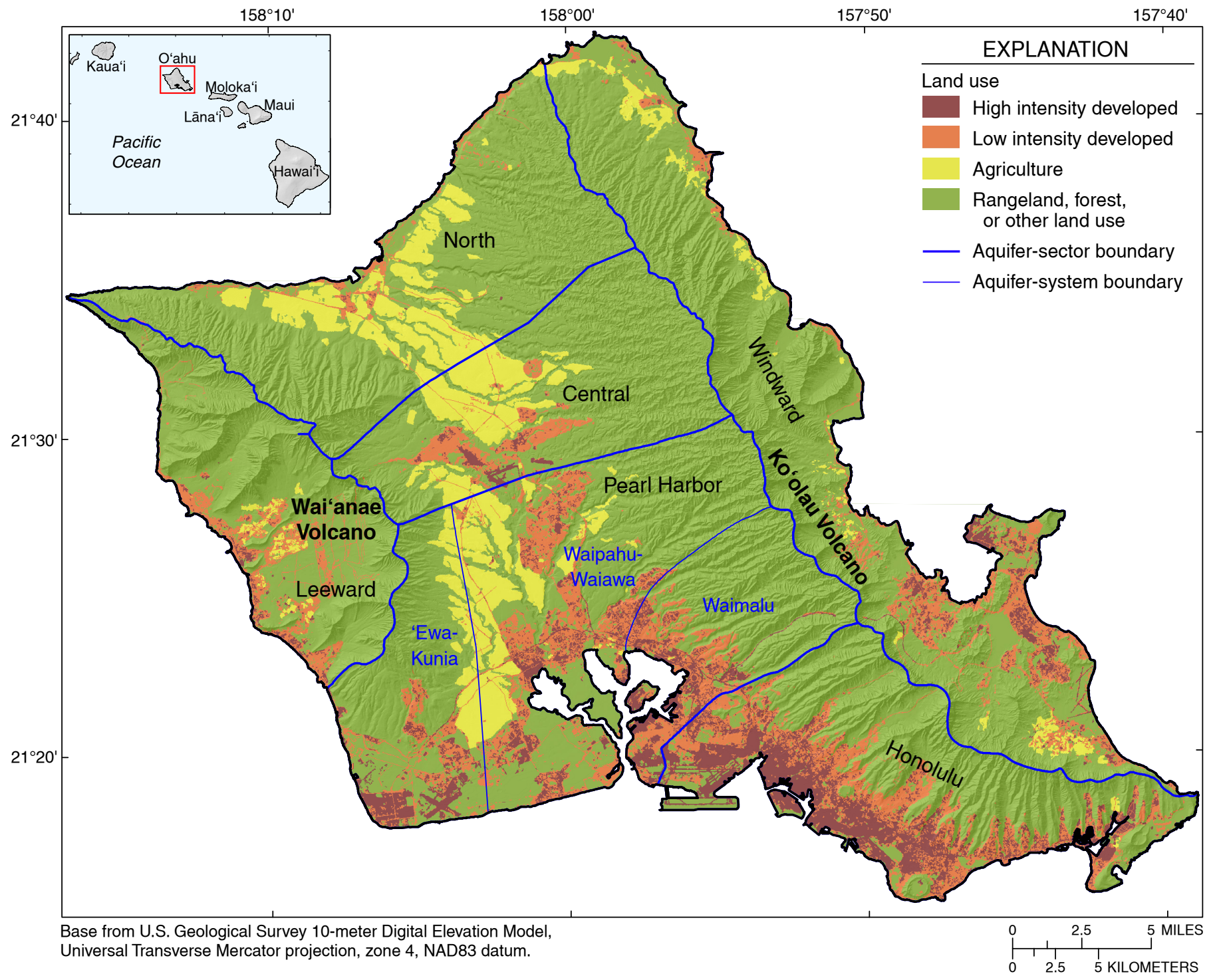

Figure 3. Generalized land use (Hawaii Gap Analysis Program, 2005) and State of Hawai'i aquifer-management systems in Pearl Harbor, O‘ahu, Hawai'i. 
flows contain ' $a$ 'à and pāhoehoe flows. Individual lava flows of the Ko 'olau Basalt range from several feet to $80 \mathrm{ft}$ in thickness with an average thickness of $10 \mathrm{ft}$. The flows usually dip between $3^{\circ}$ and $10^{\circ}$ away from their sources; in central $\mathrm{O}^{\prime}$ ahu though, dips of the Ko'olau Basalt are typically about $3^{\circ}$ (Stearns and Vaksvik, 1935). A geologic map of the island of Hawai ' $i$ indicates that individual flow widths are typically between several tens of feet and many hundreds of feet, although some flows are wider than a mile (Wolfe and Morris, 1996).

\section{Dike Zones}

The Wai 'anae and Ko'olau Volcanoes each have two primary rift zones and a third less pronounced rift zone. Within the rift zones, numerous dikes intruded existing rocks. Dikes are thin, near-vertical sheets of massive, low-permeability rock
(Stearns and Vaksvik, 1935). The abundance of dikes can be as high as 1,000 per mile in the center of the rift zone and decreases away from the center. Dikes represent 10 percent or more of the total rock volume in the center of the rift zone and less than 5 percent in the marginal dike zone (Takasaki and Mink, 1985).

\section{Sedimentary Deposits}

Changes in sea level, subsidence, and erosion of volcanic rocks contributed to deposition of sediments on coastal plains and deeply incised valley floors. The coastal plain of southern $\mathrm{O}^{\text {‘ahu }}$ consists of terrestrial and marine sediments and reef limestone deposits. The sedimentary wedge is called caprock because it forms a confining unit overlying the high-permeability flank lavas. Locally, the caprock includes cavernous, highly permeable limestone deposits; however, regionally, the permeability of

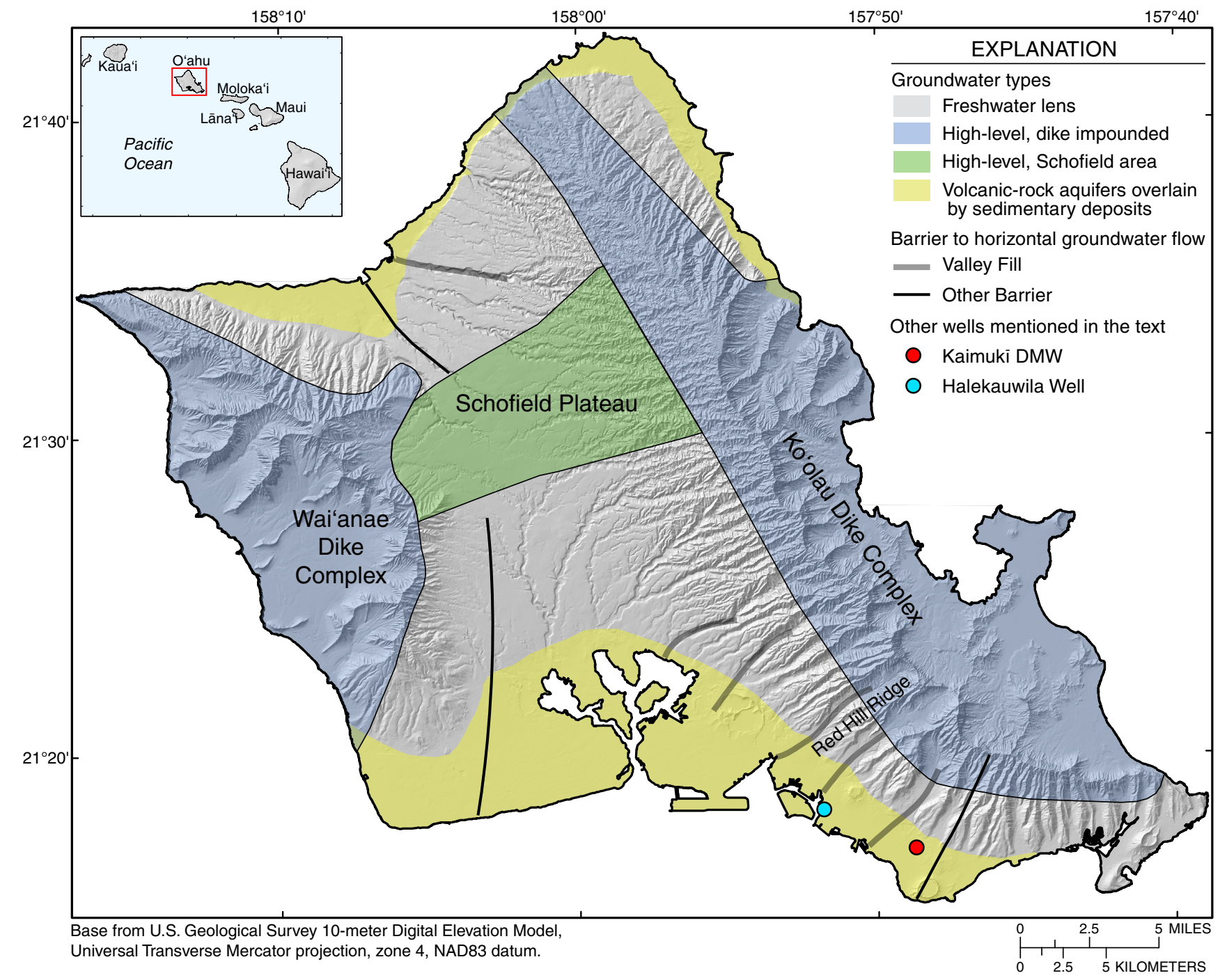

Figure 4. Map of groundwater types and general geologic features on O'ahu, Hawai'i. Also shown are locations and names of selected wells mentioned in the text. 
caprock and the weathered basalt near the base of the sedimentary deposits is lower than that of the underlying basalt. Therefore, generally the caprock impedes freshwater discharge from the volcanic-rock aquifers to the ocean. In the Pearl Harbor area, the caprock is $1,000 \mathrm{ft}$ thick near the coast and pinches out about $5 \mathrm{mi}$ inland (Visher and Mink, 1964).

\section{Hydraulic Properties of the Rocks}

The hydraulic properties of the different rock types control the groundwater occurrence and flow in the Pearl Harbor area. In general, basalts are highly permeable and form productive aquifers. Groundwater primarily occurs in flank lavas as freshwater-lens systems and high-level water in dike-impounded systems, and groundwater production on $\mathrm{O}^{\prime}$ ahu is predominantly from the freshwater-lens system. Summaries of different estimates of aquifer-parameter values can be found in Nichols and others (1996), Hunt (1996), Oki (1998), and Rotzoll (2007).

\section{Hydraulic Conductivity}

Intrinsic permeability, $k$, is a well-defined term that quantifies ease of fluid flow through porous media; $k$ is a property of the porous media only, not the fluid. Hydraulic conductivity, $K$, lumps $k$ and dynamic viscosity, $\mu$, in a single term where $K=k / \mu$ is a property of the porous media and the fluid. The term permeability used herein refers to the lumped intrinsic permeability and dynamic viscosity and is synonymous with hydraulic conductivity. Openings within lava flows and at contacts between flows contribute to the high hydraulic conductivity of the volcanic rocks. The bulk hydraulic conductivity of the dike-free flank lavas is controlled by factors including thickness of the flows and clinker zones associated with ' $a$ 'a flows, extent of fractures, occurrence of lava tubes associated with pāhoehoe flows, and degree of weathering. Flat topography favors formation of highly viscous lava and thicker flows that typically are less permeable. Rocks with a high percentage of pore space and surface area, such as ash, cinder, and ' $a$ 'ā clinker, weather preferentially. In general, weathering lowers the permeability of volcanic rocks (Lau and Mink, 2006).

Dike-free flank lavas are heterogeneous and have a regional horizontal hydraulic conductivity that ranges from hundreds to thousands of feet per day (Hunt, 1996). Low hydraulicconductivity values may be associated with massive features, including dense flows, 'a'ā cores, dikes, and thick lava flows, and high values may be associated with 'a'ā clinker zones, the contacts between individual flows, and lava tubes. Analysis of aquifer tests (Rotzoll and others, 2007), an empirical relation between specific capacity and hydraulic conductivity (Rotzoll and El-Kadi, 2008a), and groundwater-level response to ocean-tide (Rotzoll and others, 2008) and wave-setup oscillations (Rotzoll and El-Kadi, 2008b) indicated a mean hydraulic conductivity of $1,400 \mathrm{ft} / \mathrm{d}$ for dike-free flank lavas on Maui (Rotzoll, 2007). A common value used for horizontal hydraulic conductivity in numerical modeling of the Pearl Harbor area is 1,500 ft/d (Voss and Souza, 1987; Oki, 2005).
Basalt aquifers are typically anisotropic in horizontal and vertical directions. Horizontal hydraulic conductivity is greater parallel to the flow direction of lava flows than perpendicular to it (Nichols and others, 1996). Moreover, horizontal hydraulic conductivity can be as much as 200 times greater than vertical hydraulic conductivity (Souza and Voss, 1987).

In the rift zones, intrusive low-permeability dikes impede lateral groundwater flow. The bulk hydraulic conductivity of an entire dike complex ranges from 0.01 to $0.1 \mathrm{ft} / \mathrm{d}$; however, the hydraulic conductivity of individual dikes may be lower and the conductivity of rocks between dikes may be much higher (Meyer and Souza, 1995).

The overall permeability of caprock is lower than that of the underlying basalt. However, hydraulic conductivity of individual units in the caprock spans several orders of magnitude, from 0.01 to $1 \mathrm{ft} / \mathrm{d}$ for fine-grained muds and saprolite (Wentworth, 1938) to as much as several thousand feet per day for coral gravels and reef limestone deposits (Oki, 1998). Souza and Voss (1987) modeled sections of the Pearl Harbor aquifer and estimated a caprock hydraulic conductivity of $0.15 \mathrm{ft} / \mathrm{d}$. Because little information about layering and anisotropy exists, the caprock was treated as a homogeneous and isotropic unit. However, because it is highly heterogeneous, Oki (2005) divided the Pearl Harbor caprock into a high- and low-permeability unit. The upper-limestone unit was simulated with a horizontal hydraulic conductivity of 2,500 ft/d, and the low-permeability units above the Ko'olau Basalt had simulated hydraulic-conductivity values of 0.01 to $0.6 \mathrm{ft} / \mathrm{d}$.

\section{Porosity and Storage}

Effective porosity, specific storage, and specific yield affect the response time of water levels to natural and anthropogenic changes to the groundwater system. The total porosity of basaltic rocks is controlled by void spaces in the rock, vesicles, joints and cracks, separation at the contact between flows, and lava tubes. The total porosity of basaltic rocks on Oahu ranges from less than 5 to more than 50 percent. High porosity values may be associated with ' $a$ 'a clinker zones and lava tubes, and low values may be associated with massive features, including dense flows, 'a $a \bar{a}$ cores, dikes, and thick lava flows. Because not all existing pores are hydraulically interconnected and provide a pathway for groundwater flow, effective porosity may be an order of magnitude lower. Effective porosity is commonly considered to represent the porosity of a rock or sediment available to contribute to fluid flow through the rock or sediment. Effective porosity may not include water bound to clay particles and isolated porosity (not connected to other pores). Common values of effective porosity for basaltic aquifers used in numerical modeling studies are 0.1 (Gingerich and Voss, 2005), 0.05 (Oki, 1998; Whittier and others, 2010), 0.04 (Oki, 2005), and 0.03 (Rotzoll and El-Kadi, 2007). Effective porosity of the caprock was estimated to be 0.1 (Oki, 2005).

Specific storage is a measure of the compressive storage of the rocks and fluid. In the Pearl Harbor area, specific storage was estimated to range from $10^{-4}$ to $10^{-7} \mathrm{ft}^{-1}$ (Williams and Soroos, 1973). Using the compressibility of water and the volcanic rock matrix, and an effective porosity of 0.05 , the specific storage calculates to 
be about $7.6 \times 10^{-6} \mathrm{ft}^{-1}(\mathrm{Oki}, 2005)$. Specific yield is equal to or a fraction of effective porosity and is more important in the unconfined parts of the aquifers inland of the caprock extension at the surface, where most of the DMWs in the Pearl Harbor area are located (figs. 1 and 4).

\section{Dispersion Characteristics}

Mixing of freshwater and saltwater forms a brackish-water transition zone between the two water bodies. The thickness of the brackish-water mixing zone is controlled by groundwater velocity, aquifer dispersivity, ocean tides, barometric-pressure changes, recharge, and discharge.

Dispersivity primarily controls mixing and values generally are larger in the (longitudinal) direction of flow. Dispersivity values are reported for volcanic-rock aquifers of the Pearl Harbor area on $\mathrm{O}$ 'ahu in numerical modeling studies. Estimates of the horizontal longitudinal dispersivity for volcanic-rock aquifers range from 200 $\mathrm{ft}$ (Meyer and others, 1974) to $250 \mathrm{ft}$ (Souza and Voss, 1987; Gingerich and Voss, 2005; Oki, 2005). Estimated vertical longitudinal dispersivities are about $30 \mathrm{ft}$, and vertical transverse dispersivity is $0.8 \mathrm{ft}$ (Souza and Voss, 1987; Gingerich and Voss, 2005; Oki, 2005). Liu (2006) estimated vertical transverse dispersivity values ranging from 0.4 to $2 \mathrm{ft}$ from salinity profiles measured in DMWs in the Pearl Harbor aquifer. Dispersivity values for the caprock equaled the values used for the dike-free volcanicrock aquifer in most aforementioned studies; however, Oki (2005) used lower values of 10 and $0.8 \mathrm{ft}$ for horizontal longitudinal and vertical transverse dispersivity, respectively, for the lowpermeability units above the Ko'olau Basalt in his model.

\section{Groundwater Flow System}

\section{Freshwater Lens in Volcanic-Rock Aquifers}

Apart from the high-level groundwater bodies of the dike zones and the Schofield Plateau and locally perched water bodies over poorly permeable layers, most of the groundwater in southern $\mathrm{O}^{\prime}$ ahu is stored in a freshwater lens in volcanic-rock aquifers that floats on saltwater. The thickness of a freshwater lens is affected by recharge, withdrawal rates, hydraulic properties of the aquifer system, and distance from the ocean. The freshwater-lens thickness is defined as the potable part of the lens bounded vertically by the water table at the top and the depth where specific conductance is $1,000 \mu \mathrm{S} / \mathrm{cm}$ at the bottom. In the Pearl Harbor area, thick caprock sediments contribute to a large freshwater lens with thicknesses that range from $150-450 \mathrm{ft}$ in coastal areas to $700 \mathrm{ft}$ inland, measured in DMWs during 2008-2009 (Rotzoll and others, 2010).

The freshwater lens is sometimes referred to as a GhybenHerzberg lens after Badon Ghyben (1889) and Herzberg (1901). The Ghyben-Herzberg principle states that the altitude of the water table in a freshwater lens is balanced by the buoyancy of the freshwater floating on saltwater and assumes hydrostatic (nonflowing) conditions. For freshwater and saltwater densities of 1,000 and $1,025 \mathrm{~kg} / \mathrm{m}^{3}$, respectively, the Ghyben-Herzberg depth is simplified to the relation

$$
z=-40 h
$$

where $z$ is depth of the interface between freshwater and saltwater below sea level and $h$ is the water level above sea level. Although the Ghyben-Herzberg principle assumes a sharp interface between freshwater and saltwater, mixing of freshwater and saltwater in groundwater systems forms a brackish-water transition zone separating both water bodies. The assumption of hydrostatic conditions is violated in most freshwater-lens systems because vertical flow components and vertical head gradients generally exist in steady-state and in transient conditions. Thus, the GhybenHerzberg principle may not be useful for estimating the depth of the transition-zone midpoint, where substantial vertical head gradients create a vertical component to flow (Izuka and Gingerich, 1998).

Groundwater flow in freshwater-lens systems is predominantly horizontal; however, the flow has a downward component in inland recharge areas and an upward component in coastal discharge areas (Tóth, 1962). The regional groundwaterflow pattern in volcanic-rock aquifers can be summarized as follows (after Souza and Voss, 1987; Oki, 1998): (1) water from high-level groundwater bodies discharges to the freshwater-lens system; (2) most of the recharge of fresh groundwater from rainfall occurs in the mountainous interior areas, and groundwater flow has a downward component in the inland recharge areas; (3) groundwater flow is from inland recharge areas towards coastal discharge areas and is generally horizontal; (4) in the coastal area, a caprock impedes groundwater discharge to the ocean, and the flow of fresh and brackish water generally is upward into the caprock; and (5) the caprock also impedes the inflow of saltwater into the volcanic-rock aquifer (fig. 5).

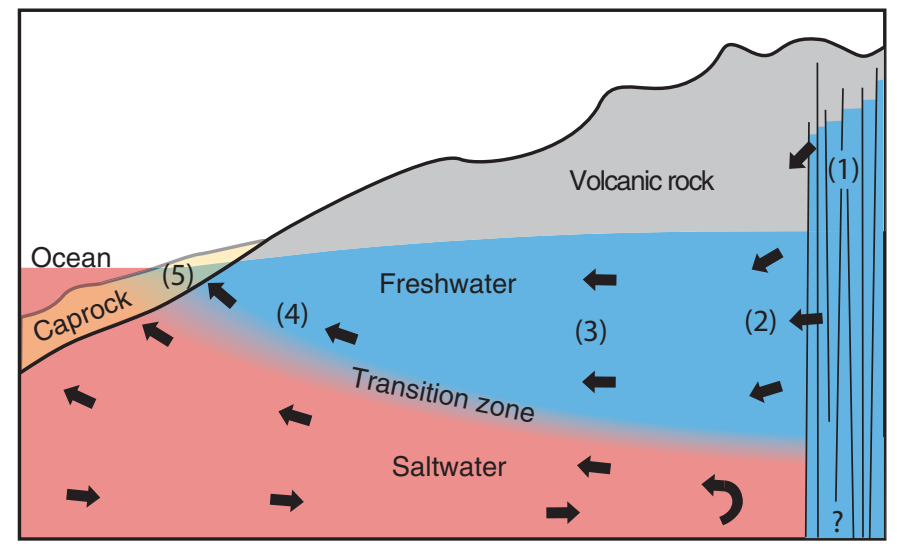

Figure 5. Generalized diagram of groundwater occurrence and movement (arrows) in the Pearl Harbor aquifer, O'ahu, Hawai'i: (1) discharge from high-level water bodies to the freshwater lens, (2) downward flow in recharge areas, (3) horizontal flow, (4) upward flow in costal discharge areas, and (5) discharge through the coastal sediments into the ocean. 


\section{Water Levels}

The volume of groundwater stored in a freshwater lens changes dynamically in response to changes in recharge and discharge. Changes in groundwater heads are measured to monitor changes in groundwater storage. Groundwater heads are typically lowest at the coast and gradually increase about $1 \mathrm{ft} / \mathrm{mi}$ in an inland direction in dike-free volcanic-rock aquifers. Local variations in the hydraulic gradient are caused by aquifer heterogeneities, discharging springs, and heavily pumped wells (Lau and Mink, 2006). Early measurements from about 1880 indicate predevelopment water levels between 32 and $42 \mathrm{ft}$ above sea level in southern $\mathrm{O}^{\text {‘ }}$ ahu. In 2002-2003, the regional water table in the Pearl Harbor area was between 13 and $20 \mathrm{ft}$ above sea level (Oki, 2005). Measured water levels in October 2002 and May 2003 were averaged to eliminate seasonal effects (fig. 6).

Hydraulic gradients also exist with depth. Generally, heads in the aquifer may decrease with depth near inland recharge areas, and heads may increase with depth near coastal discharge

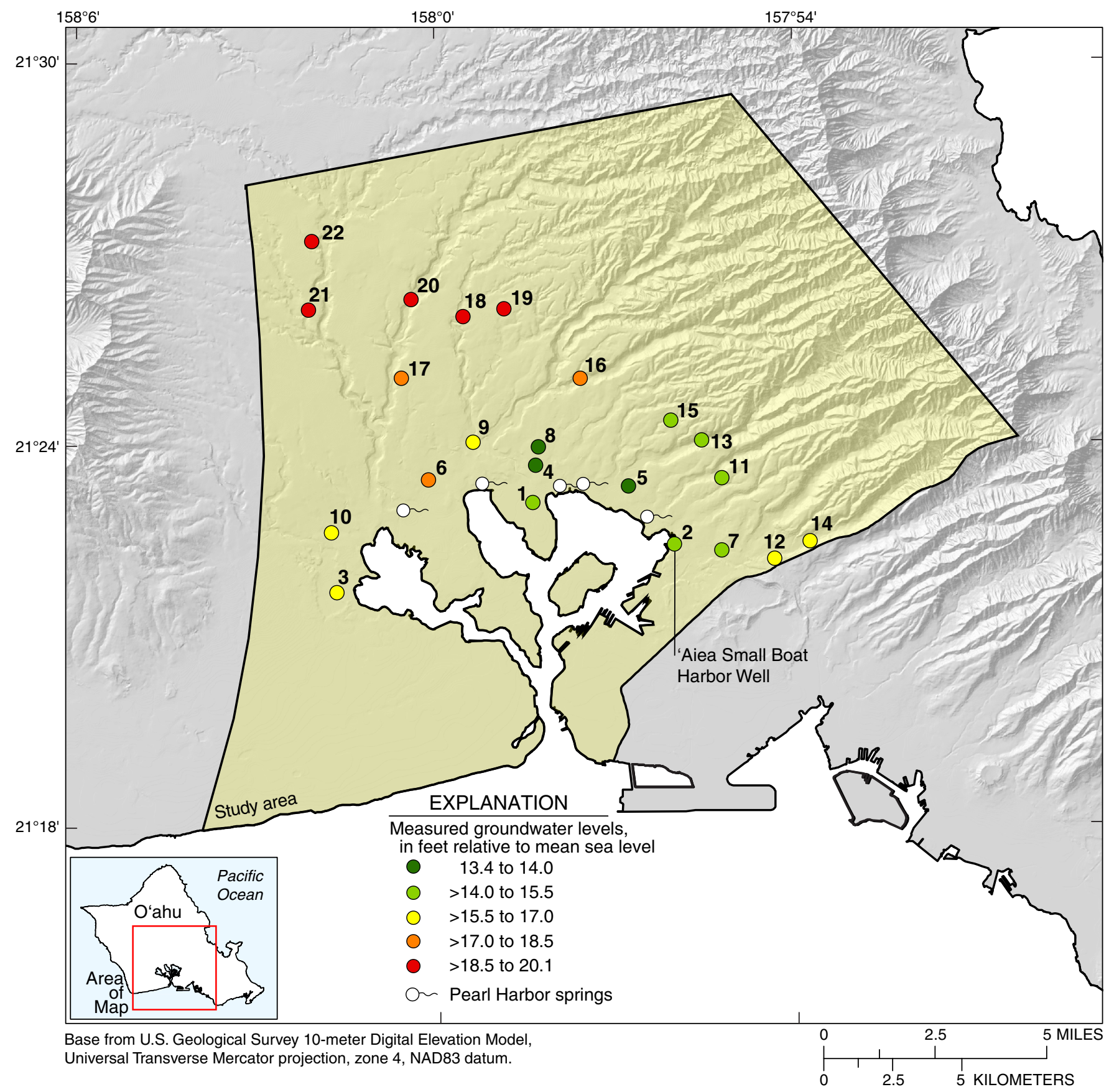

Figure 6. Average of measured groundwater levels from October 31, 2002, and May 15, 2003, in selected wells in the Pearl Harbor area, O'ahu, Hawai'i (modified from Oki, 2005). Numbers next to well symbol correspond to numbers in figure 12. 
areas. An example is Halekauwila Well, located $660 \mathrm{ft}$ inland near the coastal discharge zone of the Honolulu area (fig. 4). This artesian well has two piezometers open to the Ko'olau Basalt aquifer at altitudes of -988 and $-1,043 \mathrm{ft}$. The equivalent freshwater head is the altitude of freshwater in the well needed to balance the pressure outside of the well screen created by the denser brackish water and saltwater. The equivalent freshwater head in the deep piezometer is generally $1.5 \mathrm{ft}$ higher than in the shallow piezometer. This indicates upward flow in the aquifer due to a vertical head gradient of $0.027 \mathrm{ft} / \mathrm{ft}$ (140 ft/mi) between both piezometers, which is consistent with the regional aquiferflow concept at this location.

\section{Salinity Profiles}

Routine measuring of salinity profiles in three DMWs started in Hawai' $i$ in 1968 and, within the past 2-3 decades, more DMWs have been added to the monitoring network. In the Pearl Harbor study area, salinity profiles are collected by the HBWS and CWRM in 14 DMWs with multi-parameter sensors that measure fluid electrical conductivity, temperature, and pressure. Salinity profiles are usually taken 2-4 times per year, although data gaps exist when equipment was malfunctioning or unavailable. All recorded fluid electrical-conductivity values were converted to specific conductance at $25^{\circ} \mathrm{C}$ using the conversion given in Clesceri and others (1998):

$$
S C=\frac{E C}{1+0.0191(t-25)},
$$

where $S C$ is the specific conductance, in $\mu \mathrm{S} / \mathrm{cm} ; E C$ is the measured electrical conductivity, in $\mu \mathrm{S} / \mathrm{cm}$; and $t$ is the measured temperature, in ${ }^{\circ} \mathrm{C}$.

In Hawai 'i, the depths of the top and midpoint of the transition zone between freshwater and saltwater are defined by the depths where the specific conductance is 1,000 and $25,000 \mu \mathrm{S} / \mathrm{cm}$, respectively (fig. 1). The specific-conductance value of $1,000 \mu \mathrm{S} / \mathrm{cm}$ generally corresponds to the secondary drinking-water standard based on aesthetic concerns of $250 \mathrm{mg} / \mathrm{L}$ for chloride (U.S. Environmental Protection Agency, 2011). For the purposes of this report, ocean water was assumed to have a specific conductance of $50,000 \mu \mathrm{S} / \mathrm{cm}$, which is near the maximum value measured in DMWs in Pearl Harbor. Measured specific conductance values were divided by $50,000 \mu \mathrm{S} / \mathrm{cm}$ to obtain salinity in terms of percentage of ocean-water salinity. Brackish water is defined as water with salinity that ranges from greater than 2 to less than 100 percent ocean-water salinity.

In many DMWs in the Pearl Harbor and Honolulu areas, vertical borehole flow causes water originating from the aquifer to flow several hundred feet upwards in the borehole, mostly due to nearby groundwater withdrawals (Rotzoll, 2010). Although the top of the transition zone is monitored, change in freshwater-lens thickness is better evaluated using the midpoint, because of low confidence that the top of the transition zone represents conditions in the aquifer (Rotzoll and others, 2010).

Stepwise increases of salinity with depth indicate discrete contributions of flow to the borehole and vertical flow within the borehole. The vertical part of steps represents depth intervals over which salinity of the water is dominated by the salinity of the source water contributing flow. A step may remain nearly uniform over a specific depth interval where the flow in the borehole is vertical and controlled by a single source of flow to the borehole. Because of borehole flow and the vertical heterogeneity and anisotropy of layered Hawaiian basalt aquifers, many steps of different magnitude occur in salinity profiles due to numerous discrete contributions to borehole flow and the spatially variable natural or anthropogenically induced head gradients. Short steps smaller than $70 \mathrm{ft}$ may be related more to the presence of massive low-permeability layers and represent fluid flow between individual permeable lava flows separated by low-permeability dense lava flows penetrated by the borehole. Vertical steps longer than $70 \mathrm{ft}$ exceed the typical thickness of dense lava flows and indicate substantial borehole flow. For example, the longest vertical step in salinity in one borehole in Pearl Harbor is $644 \mathrm{ft}$. Typically, substantial borehole flow is induced by nearby groundwater withdrawals or through effects of regional withdrawals within compartmentalized aquifers near Honolulu and the east Pearl Harbor area. Long sections of a salinity profile may be affected and freshwater storage changes can be underestimated by several hundred feet (Rotzoll, 2010).

\section{Recharge}

Rainfall and irrigation that infiltrates the ground and percolates through the unsaturated zone down to the water table, and water that discharges from upgradient groundwater bodies recharges the freshwater lens in volcanic-rock aquifers. Shade and Nichols (1996) developed piecewise linear regression equations between rainfall and recharge to estimate the distribution of recharge. Using the regression equations, Oki (2005) estimated mean annual recharge of $142 \mathrm{Mgal} / \mathrm{d}$ in the Pearl Harbor area during 1995-2000. Additional recharge that entered the Pearl Harbor area from the Schofield area and from the Wai 'anae rift zone was estimated to be $100 \mathrm{Mgal} / \mathrm{d}$ and from the Ko 'olau rift zone was $19 \mathrm{Mgal} / \mathrm{d}$ during 1995-2000 (Oki, 2005).

\section{Discharge}

Discharge from the Pearl Harbor area occurs through groundwater withdrawals from pumped wells, discharge to subaerial springs inland from Pearl Harbor, and diffuse seepage through the caprock to Pearl Harbor and the ocean. Groundwater withdrawals are primarily distributed in a 3-mi-wide zone along the coastline of the Pearl Harbor water bodies (see Rotzoll, 2010). Mean annual groundwater withdrawals in the Pearl Harbor area during 1995-2000 were 
$105 \mathrm{Mgal} / \mathrm{d}$ (Oki, 2005). Withdrawals were steady at this rate during 2000-2008 (Rotzoll and others, 2010).

The Pearl Harbor springs consist of a group of springs located near the margin of the caprock inland of Pearl Harbor (fig. 6). Discharge through the onshore springs is positively correlated with head in the aquifer. Oki (1998) developed linear regression equations between spring discharge and head at a well in the eastern Pearl Harbor area. Combining the spring discharge of five major springs and dividing by the width of the Pearl Harbor aquifer at the location of the springs yields a head-dependent spring-discharge relation for generalized use:

$$
Q=0.7 h-5.3 \text {, }
$$

where $Q$ is the total Pearl Harbor spring discharge, in million gallons per day per mile of aquifer width and $h$ is the water level at "Aiea Small Boat Harbor Well (fig. 6), in feet relative to mean sea level. The diffuse seepage through the caprock has not been quantified.

\section{Simulation of Groundwater Flow}

Substantial borehole flow and displacement of salinity in DMWs over several hundred feet have been observed in a coastal freshwater lens in volcanic-rock aquifers in Hawai ' $i$. A numerical model was developed to study the effects of borehole flow on salinity measured in DMWs in the Pearl Harbor aquifer and to test whether measured salinity profiles are representative of conditions in the aquifer. The model is a representation that grossly simulates the dynamics of the Waipahu-Waiawa and Waimalu aquifer systems. Results from this study will provide insights into the magnitude of the discrepancy between measured salinity profiles and the salinities of adjacent aquifers, which is important for management and predictive modeling purposes.

\section{Model Code}

Groundwater flow in the Pearl Harbor area has been simulated with more than five numerical models. These models include but are not limited to two-dimensional areal models that assume a sharp interface between freshwater and saltwater (Oki, 1998), two-dimensional density-dependent cross-sectional flow models capable of simulating the brackish-water transition zone (Souza and Voss, 1987; Voss and Souza, 1987; Oki and others, 1998), three-dimensional models that simulate freshwater flow and well capture zones (Rotzoll and El-Kadi, 2007; Whittier and others, 2010), and three-dimensional density-dependent flow models capable of simulating the brackish-water transition zone (Gingerich and Voss, 2005; Oki, 2005).

The model developed for this study is a three-dimensional model capable of simulating variable-density groundwater flow and transport and incorporates hydrogeologic features including low-permeability caprock, onshore discharge at the Pearl Harbor springs, heterogeneous permeability layering of lava flows, and open conduits (boreholes) of DMWs. The model code used for this study was SEAWAT Version 4 (Langevin and others, 2007), which couples the USGS groundwater-flow model MODFLOW-2000 (Harbaugh and others, 2000) and the multispecies transport model MT3DMS 5.2 (Zheng and Wang, 1999). The graphical user interface ModflowGUI (Winston, 2000) facilitated the model construction and input-file preparation.

\section{Model Construction}

Groundwater flow and transport in boreholes were simulated explicitly to investigate the effects of borehole flow on salinity profiles in DMWs. A three-dimensional model is necessary for this study because the boreholes cause flow with components that are not aligned parallel to a vertical cross section. To simplify the three-dimensional model, a representative two-dimensional vertical cross section along the principal groundwater-flow direction in the Pearl Harbor aquifer was laterally expanded $2.2 \mathrm{mi}$ to a three-dimensional rectangular box.

Hydraulic properties and boundary conditions were uniform in the direction parallel to the coast, except for the boreholes and additional groundwater withdrawals. DMWs and withdrawal wells were simulated on an edge of the model domain. This effectively doubled the simulated width to 4.4 mi because symmetry was assumed about the monitoring and withdrawal wells.

Initial heads and salinity were defined with a steadystate simulation representative of the past $10 \mathrm{yr}$ to achieve an approximation of the groundwater-flow conditions and the freshwater/saltwater distribution in the Pearl Harbor area.

\section{Model Grid}

The rectangular model grid consists of 78 columns, 12 rows, and 98 layers that constitute 91,728 cells. The 15.5 mi-long representative cross section extends from the Schofield-Plateau boundary through Pearl Harbor to about $3 \mathrm{mi}$ offshore to include the zone where fresh groundwater discharges to the ocean (fig. 7). Grid spacing is variable in the vertical and horizontal directions to maximize detail in the freshwater lens and around the DMWs. Horizontal spacing is variable but does not change with depth in the model. The grid columns extend from the ocean to the inland recharge area. Grid spacing parallel to the long dimension of the model is 3,937 ft offshore and varies from 1,804 ft between DMWs to $1 \mathrm{ft}$ at locations of the simulated DMWs. The grid rows extend from east to west and represent the orientation perpendicular to the principal groundwater-flow direction. Grid spacing parallel to the short dimension of the model is $4,921 \mathrm{ft}$ on the west side and is gradually refined to $0.5 \mathrm{ft}$ on the east side. The ratio of adjacent cell sizes in the area of refinement was initially 1.45 in both horizontal directions. To reduce computation time and because modeling results were similar to those using a larger factor for cell-size change, the ratio of adjacent cell sizes used in the model is 2.45 . 
The model grid extends to $5,906 \mathrm{ft}$ below sea level to coincide with an assumed aquifer bottom (Souza and Voss, 1987). Bottom altitudes of layers are constant. Hence, layering is horizontal, except for the top layer. The top altitude of this layer is at sea level in the offshore part and changes with the surface altitude in the inland direction to a maximum of $66 \mathrm{ft}$ to allow the water table to move freely in the unconfined part of the aquifer, where basalt is at the surface. Model cells representing the ocean are considered inactive. Vertical grid spacing is finest above an altitude of $-1,096 \mathrm{ft}$, where cell thickness is $13.1 \mathrm{ft}$, except for the top layer, which has a variable thickness between 6.5 and $72.2 \mathrm{ft}$. Below an altitude of $-1,096 \mathrm{ft}$, cell thickness increases gradually to $926 \mathrm{ft}$ at the bottom three layers (fig. 8). The ratio of adjacent cell sizes is 1.6 in the vertical direction.

\section{Boundary Conditions}

The lateral extent of the modeled area is defined by boundaries that are specified flux (either no-flow or recharge): specifiedhead and specified-concentration boundaries. No-flow conditions exist at the vertical east- and west-side boundaries, below $-650 \mathrm{ft}$ at the vertical northern boundary, and at the bottom boundary of the model. Fluxes into and out of the model are estimated by dividing areal rates by the width of the Pearl Harbor aquifer to approximate general flow conditions in the aquifer.

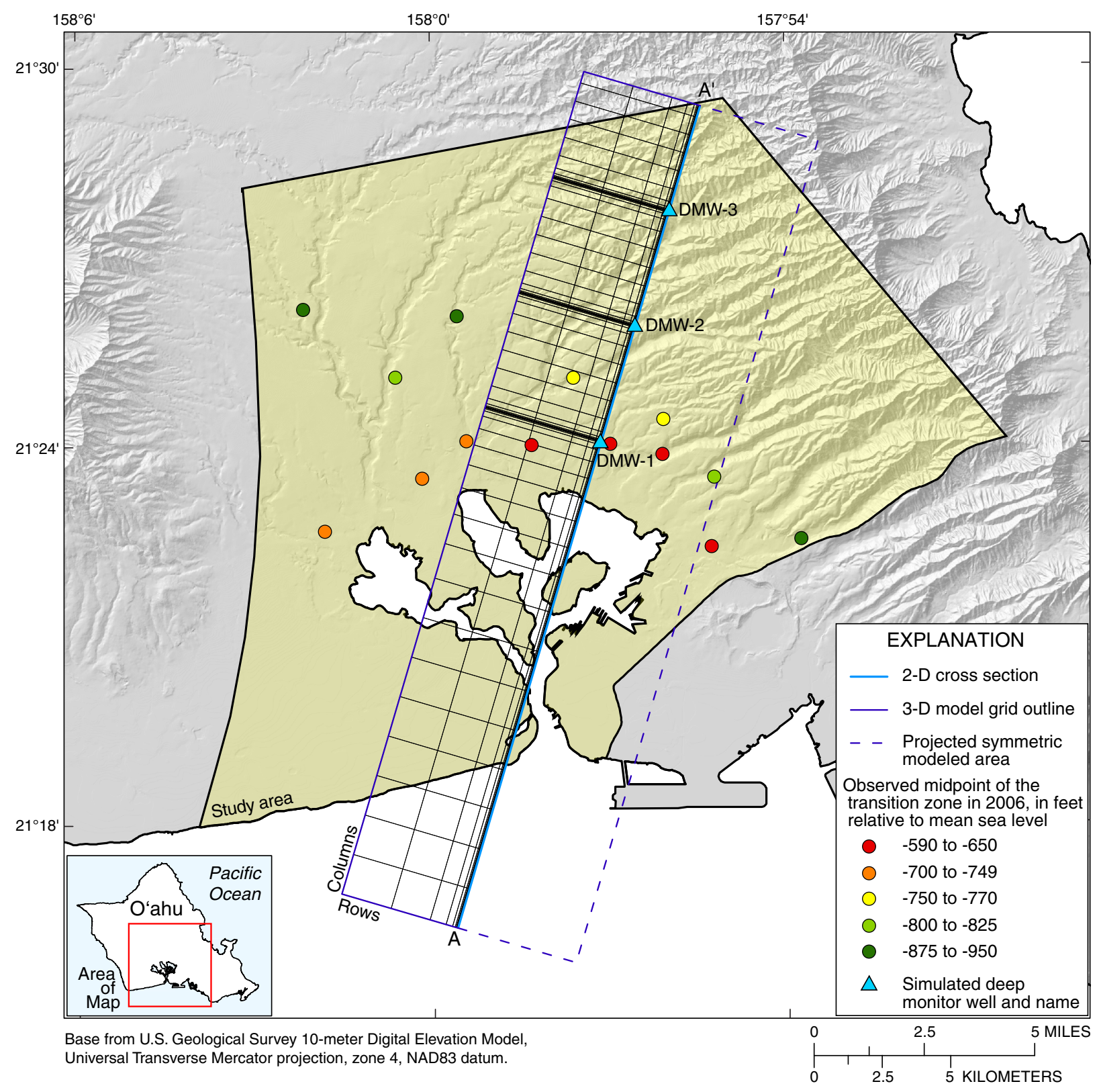

Figure 7. Location of two-dimensional vertical cross section, extent of three-dimensional model boundaries in plan view, simulated boreholes, and measured midpoint of the transition zone (modified from Rotzoll and others, 2010) in southern O’ahu, Hawai'i. 


\section{Specified-Head and Specified-Concentration Boundaries}

The offshore, vertical southern boundary of the model domain is a specified-head and specified-concentration (hydrostatic ocean-water) boundary condition. Heads in each cell along the offshore vertical southern boundary are equal to the freshwater heads of a column of ocean water extending from the cell to sea level. Water may either enter or exit the flow system across the vertical southern boundary of the model. Water entering at the vertical southern boundary has salinity equal to that of ocean water, and water exiting at the southern boundary has salinity equal to that in the adjacent cell.

The top of the active offshore model domain is defined by the ocean bathymetry. The ocean bottom boundary condition is represented with a head-dependent flux (river) boundary in the model (fig. 8). Heads and concentration along the river boundary correspond to ocean water at sea level. Ocean water may enter the
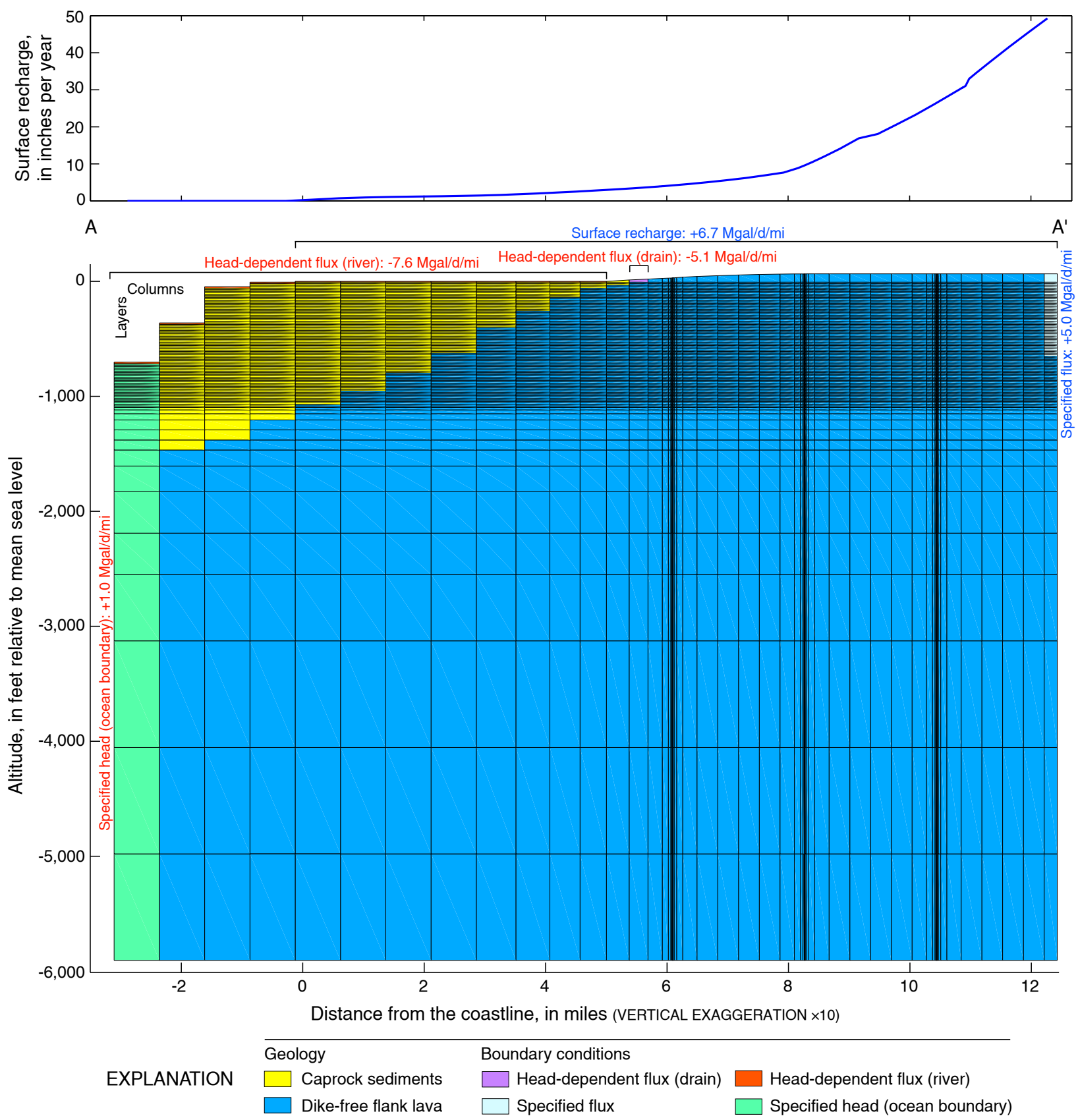

Figure 8. Cross section showing surface recharge distirbution, vertical grid discretization, contact between caprock and flank lava, boundary conditions, and specified (blue) and model calculated (red) net water flux in and out of the model in million gallons per day per mile (Mgal/d/mi). 
model domain at the top boundary in offshore areas or water from the aquifer may exit at the top boundary in offshore areas. The river boundary is extended $5 \mathrm{mi}$ inland to the Pearl Harbor coastline. The river conductance over land is scaled, based on the ratio of area of water bodies in Pearl Harbor to the total area in the WaipahuWaiawa and Waimalu aquifer systems perpendicular to the model cross section (fig. 9).

\section{Withdrawal}

Groundwater withdrawals in the Pearl Harbor area for the steady-state initial conditions and the base case are treated as reduced recharge. Withdrawals in the Pearl Harbor area were relatively steady during the past $10 \mathrm{yr}$, averaging about 7.8 Mgal/d/mi (Oki, 2005; Rotzoll and others, 2010). This rate is subtracted in equal parts from surface recharge and underflow from the northern boundary. Although this approach preserves the overall water budget, it does not accurately represent the groundwater-flow directions that would exist if the withdrawals were simulated in their actual locations. Because this potentially removes the effect of vertical gradients that are imposed on the system by local groundwater withdrawals in the steady-state case, a regional model would be necessary to include these effects. Additional local groundwater withdrawals are applied in some scenarios. Withdrawals are simulated from selected cells along the east boundary of the model grid close to (100 ft) and distant from (3,000 ft) DMW-1.

\section{Recharge}

Recharge enters the model at the top, water-table boundary in onshore areas and along parts of the northern boundary.
Surface recharge was estimated as a function of rainfall in nonagricultural lands. A piecewise linear model relating annual rainfall and annual recharge (Shade and Nichols, 1996) along with the distribution of long-term average annual rainfall (Giambelluca and others, 1986) were used to estimate the spatial distribution of average recharge over the modeled area (recharge in the model was varied only in the long direction of the model grid). Oki (2005) estimated surface recharge of 10.6 $\mathrm{Mgal} / \mathrm{d} / \mathrm{mi}$ in the Pearl Harbor area during 1995-2000. Surface recharge was reduced by $3.9 \mathrm{Mgal} / \mathrm{d} / \mathrm{mi}$ to $6.7 \mathrm{Mgal} / \mathrm{d} / \mathrm{mi}$ to account for Pearl Harbor withdrawal.

The north boundary is formed by the southern Schofield groundwater dam and the northwest rift zone of the Ko'olau Volcano. Recharge of freshwater from upgradient areas is allowed to enter the north boundary between altitudes of $66 \mathrm{ft}$ and $-650 \mathrm{ft}$ (fig. 8). The specified flux of $8.9 \mathrm{Mgal} / \mathrm{d} /$ mi inflow from high-level groundwater systems of the Ko'olau rift zone and the Schofield Plateau was reduced by 3.9 Mgal/d/mi to $5.0 \mathrm{Mgal} / \mathrm{d} / \mathrm{mi}$ to account for Pearl Harbor withdrawal. The net inflow of freshwater into the model is therefore $11.7 \mathrm{Mgal} / \mathrm{d} / \mathrm{mi}$.

\section{Spring Discharge}

Discharge from the Pearl Harbor springs was simulated from the top layer of the model using a head-dependent flux boundary (drain) located 2,755 ft inland from the Pearl Harbor coastline, near the contact between the caprock and basalt aquifer (fig. 8). The spring-discharge relations from Oki (1998) were used to quantify the conductance and bottom altitude of the drain cells (equation 3 ).

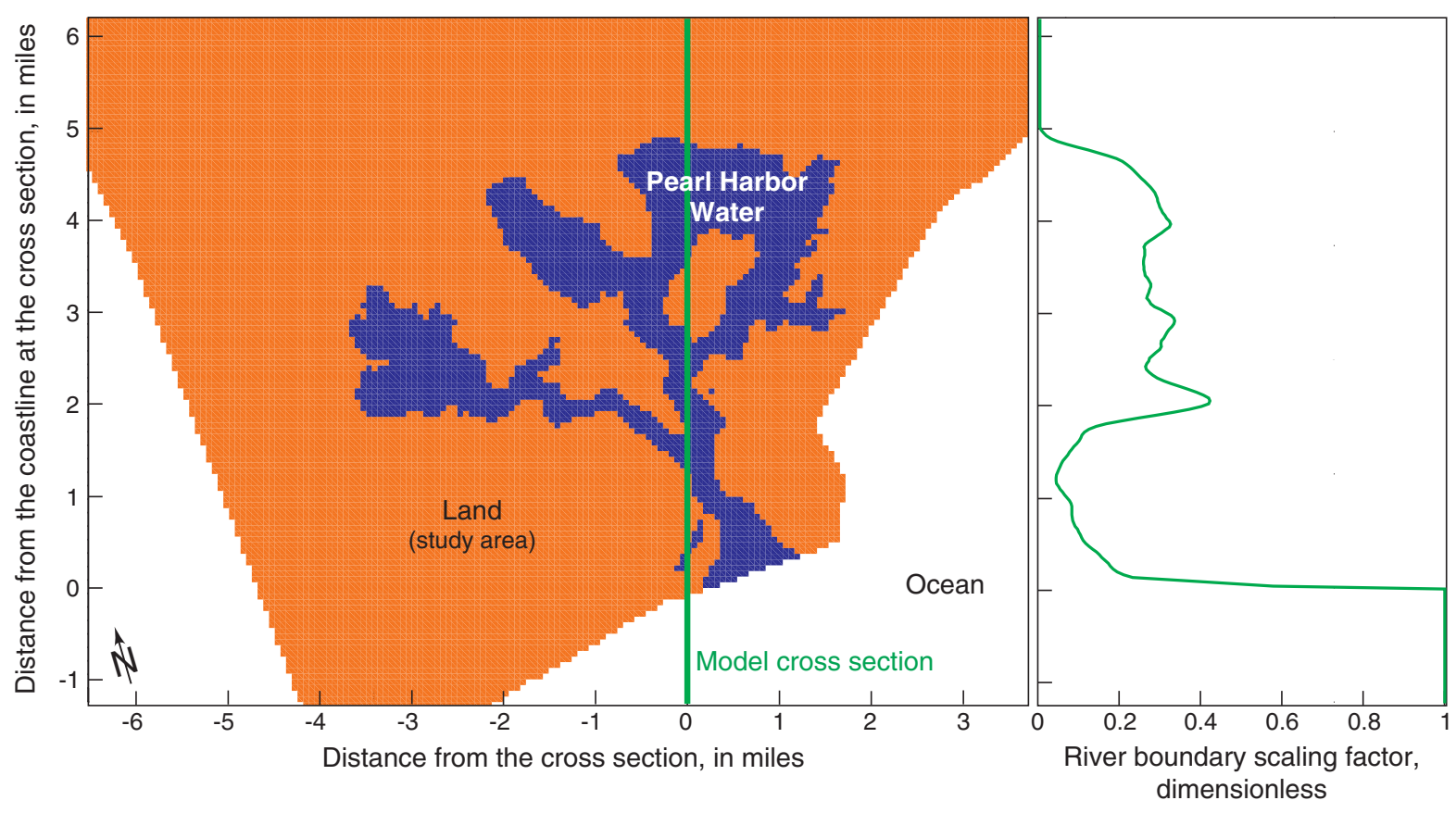

Figure 9. Ratio of area of Pearl Harbor water bodies perpendicular to model cross section to the total area of the Waipahu-Waiawa and Waimalu aquifer systems, O'ahu, Hawai'i. The ratio is used to scale the conductance of the river boundary over land. 


\section{Base-Case Conditions}

Base-case conditions were simulated to represent hydrologic conditions in the Pearl Harbor area during 2000-2010. Average recharge and withdrawal rates were estimated from published values. The base-case model consists of two geologic units, dike-free volcanic-rock aquifer and the coastal confining unit (caprock); both units are assumed to be homogeneous and anisotropic. In the model, the volcanic-rock aquifer is confined in areas that are beneath the caprock and unconfined inland of the caprock (fig. 4). The caprock was represented as a seawardthickening wedge with a geometry (fig. 8) defined by published structural contours that were modified using additional logs from more recently drilled wells (Oki, 2005). This simulation is referred to as the base case to compare with other scenarios.

\section{Water Properties}

Solute concentrations in the model are expressed as mass of total dissolved solids (TDS) per unit volume of fluid. Freshwater was assigned a TDS concentration of $0 \mathrm{~kg} / \mathrm{m}^{3}$ and ocean water was assigned a TDS concentration of $35.7 \mathrm{~kg} / \mathrm{m}^{3}$. The specific weight of water was assumed to increase linearly with salinity from $62.43 \mathrm{lb} / \mathrm{ft}^{3}\left(1,000 \mathrm{~kg} / \mathrm{m}^{3}\right)$ for freshwater to $63.99 \mathrm{lb} / \mathrm{ft}^{3}\left(1,025 \mathrm{~kg} / \mathrm{m}^{3}\right)$ for saltwater. Molecular diffusion of a solute is driven by concentration gradients in the fluid and may take place in the absence of groundwater flow. Molecular diffusion of a solute in a fluid is characterized by the molecular diffusivity. In the model, molecular diffusivity was assigned a value of $1.1 \times 10^{-3} \mathrm{ft}^{2} / \mathrm{d}$, which is similar to the values used by Voss and Souza (1987), Gingerich and Voss (2005), and Oki (2005). Because diffusion is small compared to dispersion in the aquifer, modeling results were insensitive to variations in this factor. Modeling results were also insensitive to viscosity effects; hence, the viscosity variations were not simulated.

\section{Aquifer Properties}

Hydraulic characteristics used to construct the model were based primarily on previous estimates (Souza and Voss, 1987; Gingerich and Voss, 2005; Oki, 2005). Hydraulic-conductivity values used in the model ranged from $0.2 \mathrm{ft} / \mathrm{d}$ for the caprock to $1,350 \mathrm{ft} / \mathrm{d}$ for the volcanic-rock aquifers (table 1).

Horizontal hydraulic-conductivity values for the volcanic-rock aquifers in the model were $1,350 \mathrm{ft} / \mathrm{d}$ in the longitudinal direction of the surficial lava flows (approximately perpendicular to the coastline) and $675 \mathrm{ft} / \mathrm{d}$ in the transverse direction. Vertical hydraulic conductivity of the volcanic-rock aquifers in the model was $6.8 \mathrm{ft} / \mathrm{d}$.

Although the caprock is heterogeneous (Oki and others, 1998), it is treated as a homogeneous unit in this model, because the focus is on water and solute movement in the volcanic-rock aquifer. Hydraulic conductivity of the caprock in the model ranged from $0.3 \mathrm{ft} / \mathrm{d}$ (longitudinal horizontal, and vertical directions) to $0.2 \mathrm{ft} / \mathrm{d}$ (transverse horizontal direction). The horizontal hydraulic conductivity of the cells at the seaward end of model domain was $13.5 \mathrm{ft} / \mathrm{d}$ to simulate the seaward extension of the caprock at depth and to control the ease with which saltwater enters and exits the flow system.

For the volcanic-rock and caprock aquifers, effective porosity values used in the model were 0.04 and 0.1 , respectively (table 1). The dispersivities for the volcanic-rock aquifers were assigned values of $164 \mathrm{ft}$ in the longitudinal (horizontal direction along the

Table 1. Aquifer- and well-property values used in the construction of the borehole-flow model of the Pearl Harbor area, O'ahu, Hawai'i.

[ft/d, feet per day; ft, feet; longitudinal corresponds to the horizontal direction oriented parallel to the long dimension of the model grid; transverse corresponds to the horizontal direction oriented parallel to the short dimension of the model grid; vertical corresponds to the vertical direction of the model grid]

\begin{tabular}{lccc} 
& \multicolumn{3}{c}{ Direction } \\
\cline { 2 - 4 } Parameter & Longitudinal & Transverse & Vertical \\
\hline Hydraulic conductivity, ft/d & & & \\
\hline Caprock & 0.3 & 0.2 & 0.3 \\
Basalt & 1,350 & 675 & 6.8 \\
Ocean boundary in caprock & 13.5 & 6.8 & 0.3 \\
Ocean boundary in basalt & 13.5 & 6.8 & 6.8 \\
Well, effective $\left(K_{\text {well }}\right)$ & $2.8 \mathrm{E}+05$ & $2.8 \mathrm{E}+05$ & $2.8 \mathrm{E}+05$ \\
Well, turbulent flow $\left(K_{\text {tur }}\right)$ & $1.0 \mathrm{E}+08$ & $1.0 \mathrm{E}+08$ & $1.0 \mathrm{E}+08$ \\
\hline Dispersivity, ft & & & 0.2 \\
\hline Caprock & 33 & 1.6 & 0.8 \\
Basalt & 164 & 8.2 & $6.6 \mathrm{E}-08$ \\
Well & $1.3 \mathrm{E}-05$ & $6.5 \mathrm{E}-07$ & \\
\hline Porosity and specific yield & & & \\
\hline Caprock & & 0.10 & \\
Basalt & & 0.04 & \\
Well & & 1.00 & \\
\hline
\end{tabular}


maximum hydraulic-conductivity direction) direction, $8.2 \mathrm{ft}$ in the transverse (horizontal direction perpendicular to the maximum hydraulic-conductivity direction) direction, and $0.8 \mathrm{ft}$ in the vertical direction. For the caprock aquifers, dispersivities were assigned values of $33 \mathrm{ft}$ in the longitudinal direction, $1.6 \mathrm{ft}$ in the transverse direction, and $0.2 \mathrm{ft}$ in the vertical direction.

\section{Borehole Properties}

Three DMWs were simulated on the east side of the model domain near the Pearl Harbor coastline 6.4, 8.3, and 10.4 miles inland (fig. 7). The 13.3-in.-diameter boreholes were simulated using a vertical column of cells in half-space that have horizontal dimensions of $1 \times 0.5 \mathrm{ft}$. The wells are open to the basalt aquifer at depths ranging from -20 to $-1,056 \mathrm{ft}$ relative to mean sea level. For laminar-flow conditions, the hydraulic conductivity of the well may be calculated according to Hagen-Poiseuille flow in pipes (Reilly and others, 1989):

$$
K_{\text {lam }}=\frac{r^{2} \rho g}{8 \mu}
$$

where $K_{\text {lam }}$ is the equivalent hydraulic conductivity for laminar-flow conditions in feet per day, $r$ is the well radius in feet, $\rho$ is density in slugs per cubic feet, $g$ is acceleration due to gravity in feet per second squared, and $\mu$ is dynamic viscosity in slugs per feet per second. Water was assigned a density of $1.94 \mathrm{slug} / \mathrm{ft}^{3}\left(1,000 \mathrm{~kg} / \mathrm{m}^{3}\right)$ and a viscosity of $2.1 \times 10^{-5} \mathrm{slug} \mathrm{ft} \mathrm{s}^{-1}\left(1.0 \times 10^{-3} \mathrm{~kg} \mathrm{~m}^{-1} \mathrm{~s}^{-1}\right)$, and acceleration due to gravity was assigned $32.2 \mathrm{ft} / \mathrm{s}^{2}\left(9.81 \mathrm{~m} / \mathrm{s}^{2}\right)$. A 13.3-in.diameter well has an equivalent hydraulic conductivity of $9.9 \times 10^{9} \mathrm{ft} / \mathrm{d}$. Thus, the vertical hydraulic conductivity of the well for laminar pipe flow is nine orders of magnitude greater than the vertical conductivity of the basalt aquifer.

Flow in and near the borehole is commonly turbulent and cannot be sufficiently described by laminar-flow conditions (Halford, 2000). Reynolds numbers above 2,000 generally characterize nonlaminar pipe flow, and the Reynolds number is defined as

$$
\operatorname{Re}=\frac{2 r u \rho}{\mu}
$$

where Re is the dimensionless Reynolds number and $u$ is the average flow velocity in the well in feet per day. For example, nonlaminar flow can be expected when the flow velocity in a 13.3-in.-diameter well exceeds $1,700 \mathrm{ft} / \mathrm{d}$.

For turbulent flow conditions, the hydraulic conductivity of the well is inversely proportional to the flow velocity (Chen and Jiao, 1999):

$$
K_{t u r}=\frac{4 r g}{u f},
$$

where $K_{t u r}$ is the equivalent hydraulic conductivity for nonlaminar flow conditions in feet per day, and $f$ is the dimensionless friction factor. The friction factor for turbulent flow can be estimated using the empirically derived Sacham formula (Geankoplis, 1993):

$$
f=\left(-2 \log \left(\frac{\varepsilon}{7.4 r}-\frac{5.02}{\operatorname{Re}} \log \left(\frac{\varepsilon}{7.4 r}+\frac{14.5}{\operatorname{Re}}\right)\right)^{-2},\right.
$$

where $f$ is the dimensionless friction factor for nonlaminar flow and $\varepsilon$ is the absolute pipe roughness in feet.

Caliper logs of DMWs in the Pearl Harbor and Honolulu area indicate highly uneven borehole walls (Rotzoll, 2010).

The deviation of the uncased borehole diameter from the mean borehole diameter suggests an absolute roughness between 0.5 and $0.65 \mathrm{ft}$ in these DMWs. For such large roughness values, the friction factor varies little with increasing flow velocities; thus, a constant friction factor of 0.4 can be used for uncased wells in Pearl Harbor. Maximum measured borehole-flow rates under high nearby pumping conditions in Punanani DMW in Pearl Harbor were approximately $0.1 \mathrm{Mgal} / \mathrm{d}$, which corresponds to a borehole-flow velocity of $1.4 \times 10^{4} \mathrm{ft} / \mathrm{d}$ (Rotzoll, 2010). Equation 5 then yields an equivalent hydraulic conductivity for turbulent flow of $1.0 \times 10^{8} \mathrm{ft} / \mathrm{d}$, two orders of magnitude lower than the conductivity for the same well in laminar-flow conditions.

Model sensitivity to the well hydraulic conductivity in the base-case scenario was tested. At lower well conductivities, borehole flow increases linearly with increasing well conductivity, which is the main controlling factor for borehole flow (fig. 10A). At higher well hydraulic conductivities, the flow through the well ceases to increase, because the hydraulic conductivity of the aquifer limits the amount of water that can be supplied to the well (Elci and others, 2001). Maximum flow velocities reach $750 \mathrm{ft} / \mathrm{d}$ in DMW-2 and 6,000 ft/d in DMW-1 and DMW-3. Borehole flow in DMW-3 reaches the plateau at higher well conductivities than the other two wells.

Displacement of salinity in the well was assessed by comparing the simulated top and midpoint of the transition zone depth in the borehole and the simulated top of transition zone depth in the aquifer without a borehole. Practically, this comparison was made by running two separate simulations: one with and one without a borehole. Positive and negative displacements signify upward and downward movement, respectively.

At high well conductivities, the magnitude of displacement of the top-of-transition-zone depth exceeds 220 $\mathrm{ft}$ in DMW-1 and $40 \mathrm{ft}$ in DMW-2 and DMW-3 (fig. 10B). However, the midpoint of the transition zone depths are less affected by borehole flow than the top-of-transition-zone depths. Displacement of the midpoint of the transition zone is less than $7 \mathrm{ft}$ in all three wells at all tested well conductivities (fig. 10C). The effect of well conductivity on borehole flow and displacement of the top of transition zone depth indicates (1) simulated flow velocities using $K_{t u r}$ are within 5 percent of the flow velocities using $K_{\text {lam }}$ in both DMW-1 and DMW-2 and (2) 
simulated displacements of the top of the transition zone using $K_{t u r}$ are within 5 percent of the displacements using $K_{\text {lam }}$ in both DMW-1 and DMW-2.

A test on the sensitivity of the vertical aquifer hydraulic conductivity showed that doubling the vertical aquifer conductivity results in about half the peak borehole-flow velocity and half the displacement of top and midpoint of the transition zone in all three simulated wells due to the smaller aquifer-well conductivity contrast.

Numerical models commonly are unstable for highly contrasting conductivities between well and aquifer when solved in a single domain (Halford, 2000). Furthermore, entry head losses occur because of wellbore damage, partial penetration, and turbulent entry losses in observation wells where discrete flow intervals occur (Garcia and others, 2010). To account for entry losses, an effective hydraulic conductivity of the well was introduced, which is a reasonable simplification because the heterogeneous layering of the basalt aquifer has numerous alternating low- and high-permeability zones causing discrete flow intervals in the well.

The effective hydraulic conductivity of the well $\left(K_{\text {well }}\right)$ was estimated by comparing simulated and observed boreholeflow velocities in DMWs. Borehole flow was measured in Punanani DMW with nearby withdrawal of $16.7 \mathrm{Mgal} / \mathrm{d}$ and in Kaimukī DMW with nearby withdrawal of $3.8 \mathrm{Mgal} / \mathrm{d}$ (Rotzoll, 2010). The DMWs are located at similar distances from the shoreline, both are about $90 \mathrm{ft}$ from nearby production wellfields, and the production wells are screened at similar depth intervals. Observed borehole-flow velocities are highly variable, mainly because of the irregular borehole diameter. Therefore, the simulated flow was generally matched to the observed flow profiles using the effective well hydraulic conductivity of $2.8 \times 10^{5} \mathrm{ft} / \mathrm{d}$ (see model results from scenarios 7 and 8 described below).

The lower $K_{\text {well }}$ results in lower borehole flows than those simulated with the theoretical $K_{\text {lam }}$ or $K_{\text {tur }}$. Due to uncertainty of the borehole conductivity, selected simulations were also run with the higher $K_{t u r}$ to provide a bracketing range of results. The actual well conductivity may be between the two values, with higher confidence towards the effective $K_{\text {well }}$.

For all simulations, the porosity and specific yield of the well were set equal to 1 . Dispersion was assumed to be small relative to advection inside the borehole. Longitudinal dispersivity within the well was $1.3 \times 10^{-5} \mathrm{ft}$ (table 1 ), which is close to the molecular diffusivity under maximum observed flow velocities.

\section{Evaluation of Simulated "Steady-State" Initial Condition}

Freshwater inflow occurs at the top and inland side of the domain, creating a freshwater lens floating on saltwater and a transition zone between freshwater and saltwater (fig. 11). Inflow of saltwater at the offshore constant-head boundary
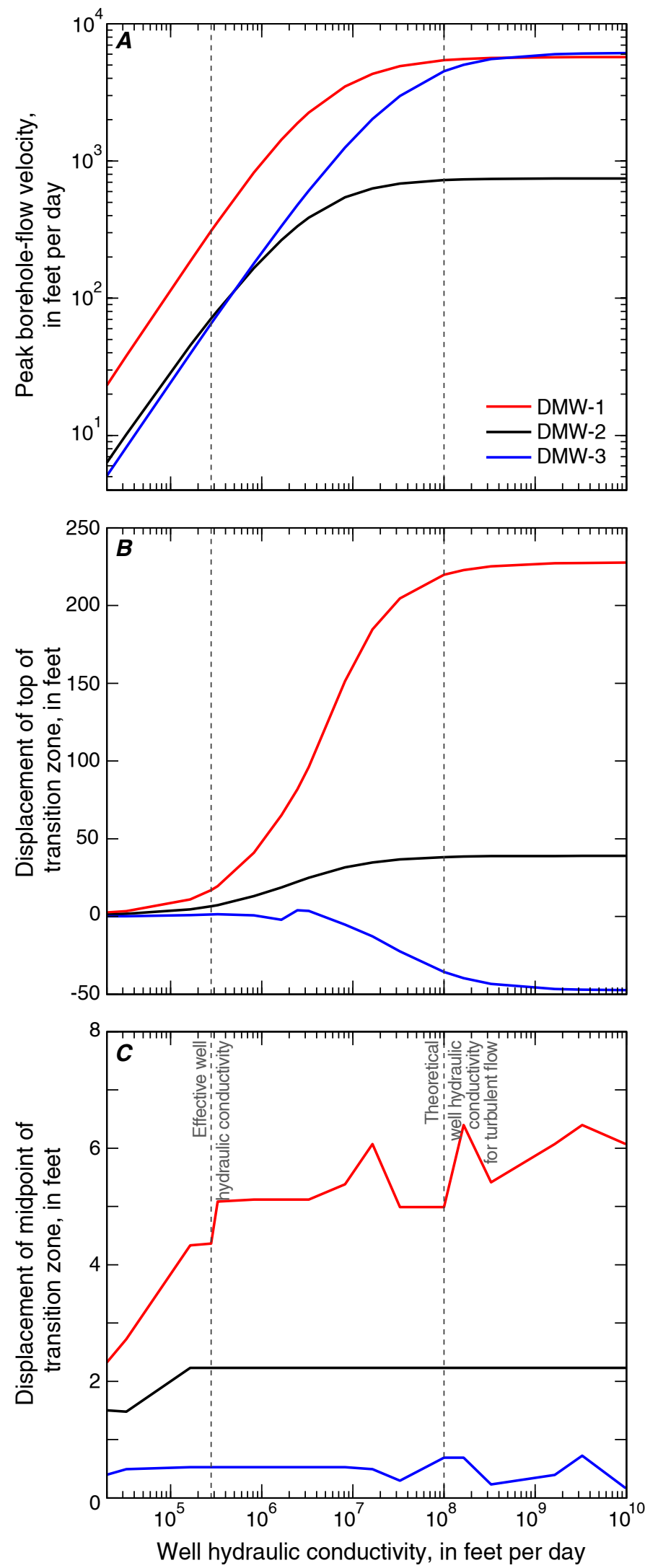

Figure 10. Sensitivity analysis of well hydraulic conductivity. A, Peak borehole-flow velocity. $B$, Displacement of top of transition zone depth. $C$, Displacement of midpoint of transition zone depth. See figure 7 for simulated deep monitor well (DMW) locations. 

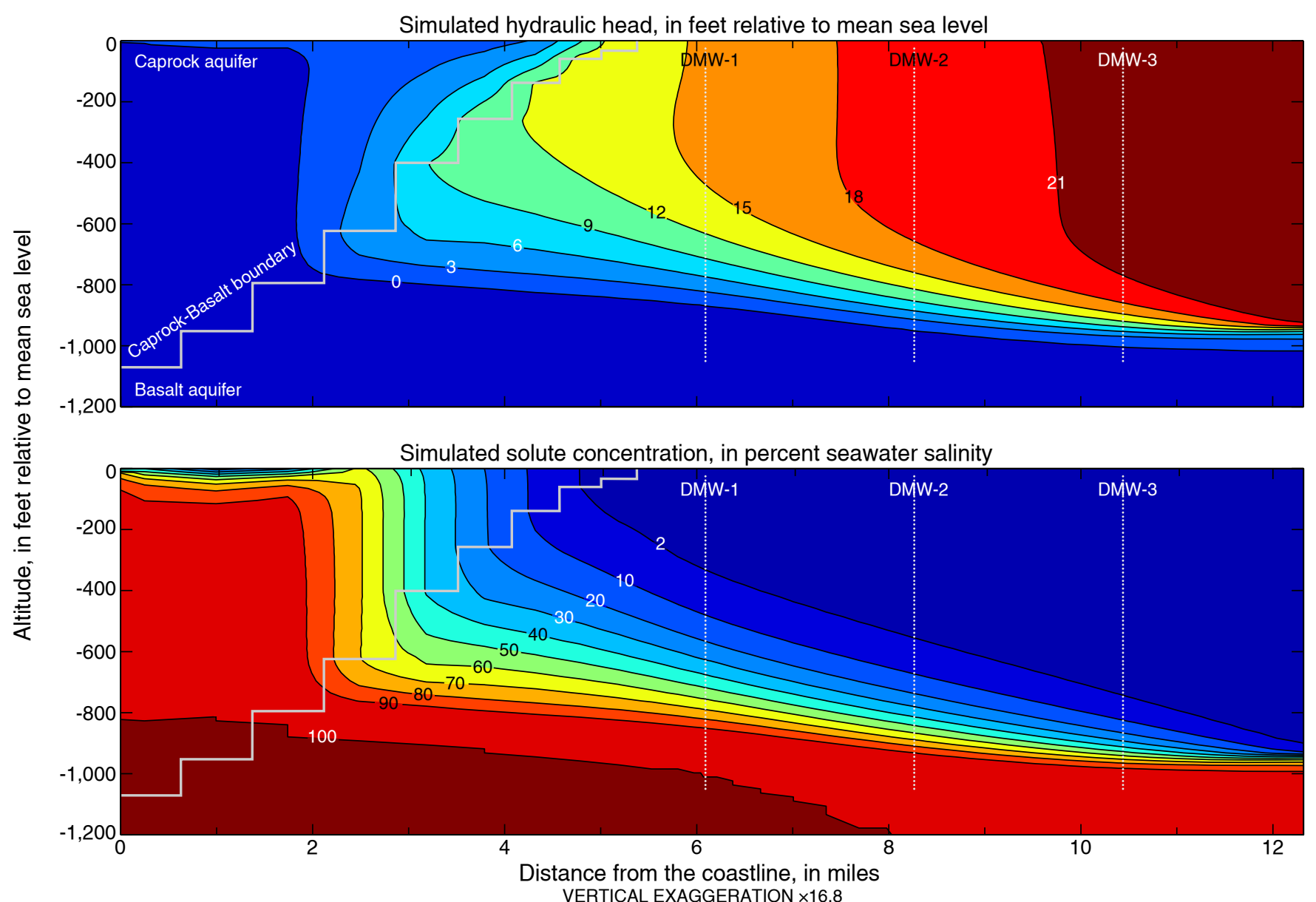

Figure 11. Cross section of simulated hydraulic head and solute concentration for the initial condition.

is $1.1 \mathrm{Mgal} / \mathrm{d} / \mathrm{mi}$ of aquifer width, and outflow of fresh and brackish water through leakage at the seafloor and the inland river boundary is $7.6 \mathrm{Mgal} / \mathrm{d} / \mathrm{mi}$. The freshwater lens has its maximum thickness inland and thins towards the coast. The transition zone broadens in direction towards the ocean due to increased mixing. Simulated hydraulic heads decrease in the coastal direction and with depth and are lower in the caprock aquifer than in the basalt aquifer. The simulated horizontal hydraulic gradient of $1.3 \mathrm{ft} / \mathrm{mi}$ is comparable to the observed gradient. The simulated water level in the drain cells is $13.6 \mathrm{ft}$, and the simulated spring discharge is $5.1 \mathrm{Mgal} / \mathrm{d} / \mathrm{mi}$.

Measured water levels from representative wells in the modeled area (fig. 6) were projected onto the eastern edge of the model with respect to distance from the shoreline and compared with simulated water levels. Simulated water levels generally are consistent with the 22 observed water levels (fig. 12). The root-mean-square error between observed and simulated water levels is $1.2 \mathrm{ft}$. Much of the scatter results from simplified hydraulic property distributions and the crosssectional simulation of the aquifer system. In addition, some of the discrepancy may be related to simulating 2000-2010 "steady-state" conditions, and measured heads from 2002 and 2003 may not be representative of the 10-yr average or long-term conditions. In fact, during 2002-2003, water levels

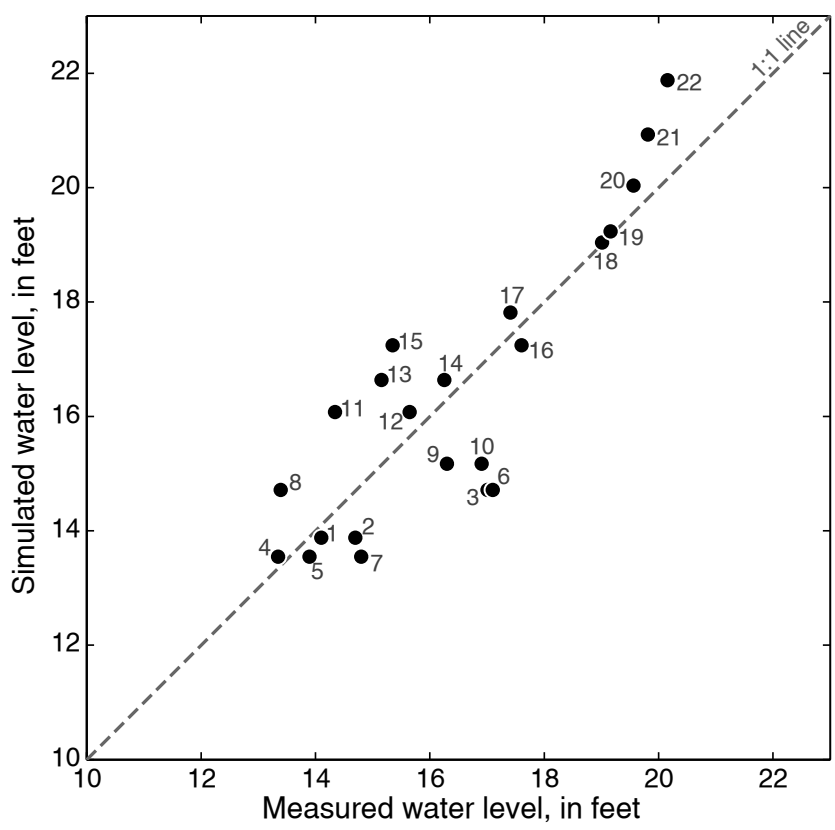

Figure 12. Simulated "steady-state" water levels compared to measured water levels in selected wells in the Pearl Harbor area, O’ahu, Hawai'i. Numbers next to points correspond to numbers in figure 6 . 
were lower than the 2000-2010 average water levels because of drought conditions (Rotzoll and others, 2010). Because the measured 2002-2003 water levels were used for calibration, the hydraulic conductivity may be overestimated. Moreover, the estimated distributions of recharge and reported groundwater-withdrawal rates are averaged over a 10 -yr period and do not include seasonal or interdecadal variations, nor are spatial differences of recharge and groundwater withdrawals in the east-west direction modeled.

Simulated and measured salinity profiles generally agree in DMWs around the Pearl Harbor area (fig. 13). Measured profiles were selected from those that include the bottom part of the profile and were from 2004-2006 (the wells commonly are logged only slightly below the depth of the midpoint of the transition zone where salinity is 50 percent seawater salinity). Measured salinity profiles do not exist for locations inland near the simulated DMW-3 (fig. 7).

The simulated midpoint depth is consistent with measured midpoints, although it differs by $50 \mathrm{ft}$ near DMW-2, indicating that a thicker freshwater lens exists $8 \mathrm{mi}$ farther inland than simulated. However, it was more important to match measured water levels and the hydraulic gradient rather than salinity profiles because of the uncertain effects of borehole flow on measured salinity with depth (Rotzoll, 2010). Borehole flow and local groundwater withdrawals may be related to some of the discrepancy between simulated and measured salinity profiles.

Results from this steady-state simulation were the initial conditions for all model scenarios that simulated the effects of borehole flow on salinity profiles in DMWs. Although the initial conditions represent average conditions of the last $10 \mathrm{yr}$ in the Pearl Harbor aquifer, the model is not designed to simulate actual conditions (regional groundwater levels, freshwater-lens thickness, drawdown, upconing) in the aquifer. It is merely designed to facilitate understanding of general concepts related to borehole flow in a coastal freshwater lens similar to the groundwater system in the Pearl Harbor area.


Figure 13. Simulated "steady-state" and measured salinity in selected deep monitor wells (DMWs) in the Pearl Harbor area, O'ahu, Hawai'i. 


\section{Simulation of the Effects of Borehole Flow on Salinity Profiles}

Borehole flow and salinity profiles in DMWs were simulated with the borehole-flow model. The effects of regional aquifer flow, groundwater withdrawals, and aquifer heterogeneity on borehole flow were investigated with eight scenarios (table 2). Scenario 1 was run to achieve a true steady state based on the initial conditions, meaning that changes of head and concentration with time were negligible. Scenarios 2-6 were run for $1 \mathrm{yr}$ and scenarios 7-8 were run for 2 days to be consistent with conditions during observations. (Most scenarios were also run for longer than $40 \mathrm{yr}$ until a steady state was achieved, but the results are not included in this report. Long-term simulations indicate an increase of upconing and, thereby, a shrinking of the freshwater-lens thickness in areas of additional groundwater withdrawals. Borehole flow and salinity in and near DMWs are generally similar to the 1-yr simulation results, although flow and salinity changes in the borehole decrease around 10 percent compared to the $1-\mathrm{yr}$ simulations due to mixing of borehole water with aquifer water.)

For each modeled scenario, results are shown in terms of simulated salinity in the boreholes and aquifer and simulated flow in the boreholes. Displacement of the top-oftransition-zone depth ( 2 percent salinity), displacement of the midpoint depth (50 percent salinity) (fig. 14A), average salinity difference between aquifer and borehole, and vertical-flow velocities are documented.

The average salinity difference between borehole and aquifer is calculated from the midpoint of the transition zone upwards to provide an indicator of changes in salinity in the well (fig. 14B). Because aquifer and borehole salinity differ mostly in the upper half of the transition zone, the average of the salinity differences is considered from the midpoint to the water table only. Whereas the displacement of 2 percent and 50 percent salinity describes a vertical shift of salinity in the well compared to salinity in the aquifer, the average salinity difference describes the overall change of salinity in the borehole compared to the aquifer.

Positive values indicate upward displacement of salinity, increase in average seawater salinity, or upward flow in the DMW. Accordingly, negative values indicate downward displacement of salinity, decrease in average seawater salinity, or downward flow in the DMW.

\section{Regional Aquifer Flow}

Scenario 1a.-Scenario 1a is the base-case scenario using the effective $K_{\text {well }}$ for the borehole in a homogeneous aquifer with no additional groundwater withdrawals. Model results indicate that the simulated salinity distribution is similar in the DMWs and in the aquifer (fig. 15A).

Displacements of the 2 percent salinity depth in DMW-1, DMW-2, and DMW-3 are 17, 6.6, and $1.3 \mathrm{ft}$, respectively (table 3). Displacement of the 50 percent salinity depth is

Table 2. Summary of scenarios tested in the borehole-flow model of the Pearl Harbor area, O'ahu, Hawai'i.

[DMW, deep monitor well; ft/d, feet per day; Mgal/d, million gallons per day; ft, feet; --, not applicable; shading indicates scenarios using the well hydraulic conductivity for turbulent flow]

\begin{tabular}{ccccccc}
\hline Scenario & Aquifer type & $\begin{array}{c}\text { Hydraulic } \\
\text { conductivity } \\
\text { of DMW, in } \\
\text { ft/d }\end{array}$ & $\begin{array}{c}\text { With- } \\
\text { drawal } \\
\text { type }\end{array}$ & $\begin{array}{c}\text { Additional } \\
\text { withdrawal, } \\
\text { in Mgal/d }\end{array}$ & $\begin{array}{c}\text { Distance } \\
\text { between } \\
\text { pumped well } \\
\text { and DMW-1, } \\
\text { in ft }\end{array}$ & $\begin{array}{c}\text { Duration of } \\
\text { simulation }\end{array}$ \\
\hline $\mathbf{1 a}$ & Homogeneous & $2.8 \mathrm{E}+05$ & -- & 0.0 & -- & steady state \\
$\mathbf{1 b}$ & Homogeneous & $1.0 \mathrm{E}+08$ & -- & 0.0 & -- & steady state \\
\hline $\mathbf{2 a}$ & Homogeneous & $2.8 \mathrm{E}+05$ & Well & 4.3 & 100 & 1 year \\
$\mathbf{2 b}$ & Homogeneous & $1.0 \mathrm{E}+08$ & Well & 4.3 & 100 & 1 year \\
$\mathbf{3 a}$ & Homogeneous & $2.8 \mathrm{E}+05$ & Well & 16.7 & 100 & 1 year \\
$\mathbf{3 b}$ & Homogeneous & $1.0 \mathrm{E}+08$ & Well & 16.7 & 100 & 1 year \\
\hline $\mathbf{4}$ & Homogeneous & $2.8 \mathrm{E}+05$ & Well & 4.3 & 3,000 & 1 year \\
$\mathbf{5}$ & Homogeneous & $2.8 \mathrm{E}+05$ & Well & 16.7 & 3,000 & 1 year \\
$\mathbf{6}$ & Homogeneous & $2.8 \mathrm{E}+05$ & Shaft & 16.7 & 3,000 & 1 year \\
$\mathbf{7}$ & Heterogeneous & $2.8 \mathrm{E}+05$ & Well & 3.8 & 100 & 2 days \\
$\mathbf{8}$ & Heterogeneous & $2.8 \mathrm{E}+05$ & Well & 16.7 & 100 & 2 days \\
\hline
\end{tabular}


$4.4 \mathrm{ft}$ in DMW-1, $2.2 \mathrm{ft}$ in DMW-2, and only 0.7 ft in DMW-3. The average salinity difference ranges from 0.65 percent seawater salinity in DMW-1 to 0.06 percent salinity in DMW-3. Commonly, a 1 percent error in salinity is acceptable for numerical modeling studies.

General flow directions in the boreholes (fig. 15C) are consistent with the directions of the regional flow in the aquifer (fig. 15B). Borehole flow is directed upward in DMW-1 and the flow in DMW-3 is mainly downward. Flow in DMW-2 is downward in the upper zone due to recharge and upward in the bottom zone due to saltwater-return flow moving from underneath the freshwater lens upwards toward the coastal boundary.

Vertical velocity of flow in the boreholes is more than five orders of magnitude greater than the comparable velocity of groundwater in the aquifer without a borehole. Boreholeflow velocities are between 0 and $310 \mathrm{ft} / \mathrm{d}$ in DMW-1, between -61 and $71 \mathrm{ft} / \mathrm{d}$ in DMW-2, and between -210 and $7.5 \mathrm{ft} / \mathrm{d}$ in DMW-3 (table 4). The maximum borehole-flow rate in DMW-1 is $1.6 \mathrm{gal} / \mathrm{min}$ or $0.002 \mathrm{Mgal} / \mathrm{d}$. The borehole flow can be directly attributed to the assigned well hydraulic conductivity, which is five orders of magnitude greater than the vertical conductivity of the basalt aquifer. However, using the effective well hydraulic conductivity, borehole flow under natural groundwater-flow conditions causes small changes of salinity in DMWs (fig. 16A).

Scenario 1b. - Scenario $1 \mathrm{~b}$ is the base-case scenario using the theoretical well hydraulic conductivity $\left(K_{t u r}\right)$ associated with turbulent flow for the borehole in a homogeneous aquifer with no additional groundwater withdrawals. Displacements of the 2 percent salinity depth in DMW-1, DMW-2, and DMW-3 are 220, 38, and $-36 \mathrm{ft}$, respectively (fig. 17A). Consistent with the regional aquifer flow concept, the top of transition zone depth in DMW-1 is shallower than in the aquifer and, in DMW-3, it is
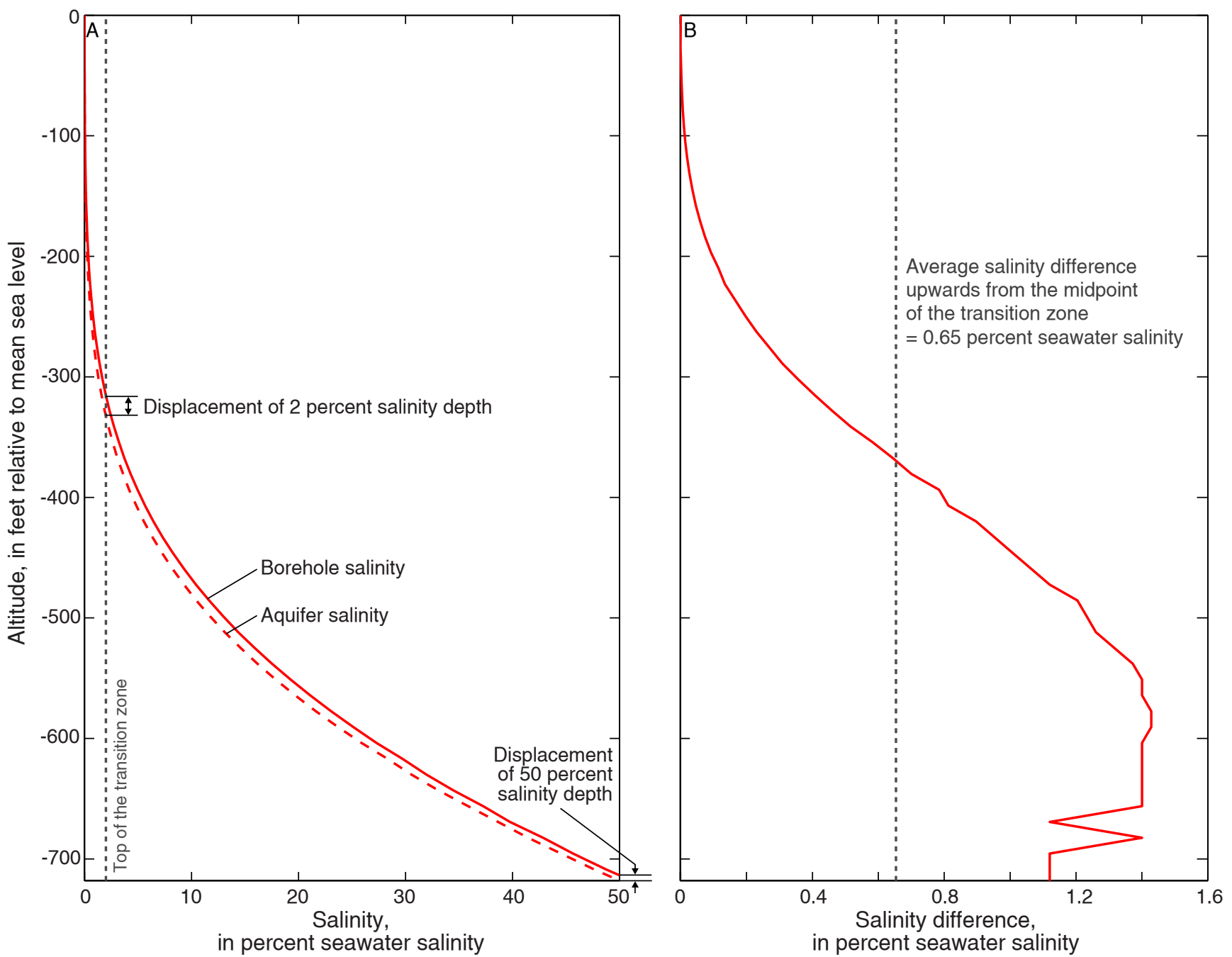

Figure 14. Compared features of simulated aquifer-and borehole salinity. $A, 2$ and 50 percent salintiy placement. $B$, Average salinity difference between aquifer and borehole from the midpoint of the transition zone upwards. 
deeper (table 3). Displacements of the 50 percent salinity depth are similar to displacements in scenario 1a and do not exceed $6.4 \mathrm{ft}$. However, the average salinity difference between borehole and aquifer is 2.9 percent seawater salinity in DMW-1, which is notable because the limit for drinking-water standards is less than 2 percent salinity.

Borehole-flow velocities are much higher in scenario $1 \mathrm{~b}$ compared to velocities from scenario 1a, because of the higher hydraulic conductivity of the well simulated in scenario $1 \mathrm{~b}$. Borehole-flow velocities are between 0 and 5,500 ft/d in DMW-1, between -880 and $720 \mathrm{ft} / \mathrm{d}$ in DMW-2, and between $-15,000$ and $4 \mathrm{ft} / \mathrm{d}$ in DMW-3 (fig. 17B). The shapes of the velocity-depth profiles are similar for both scenarios (1a and 1b) in DMW-1 and DMW-2; though, the depth of maximum downward flow in DMW-3 occurs more than $200 \mathrm{ft}$ deeper in scenario $1 \mathrm{~b}$ than in scenario $1 \mathrm{a}$. Using the higher well hydraulic conductivity, borehole flow under natural groundwater-flow conditions increases more than an order of magnitude and 2 percent salinity depth in DMW-1 occurs 200 $\mathrm{ft}$ shallower than in scenario 1a (fig. 16B).

\section{Withdrawal Near Deep Monitor Wells}

Additional groundwater withdrawals from a well were simulated $100 \mathrm{ft}$ from DMW-1 in scenarios 2 and 3 (table 2), which is approximately the distance between DMWs and some production wellfields in the Pearl Harbor area (for example, Punanani pumping station). The simulated production well was located between DMW-1 and DMW-2, and the distance to DMW-2 is $2.2 \mathrm{mi}$. Groundwater withdrawals were $4.3 \mathrm{Mgal} / \mathrm{d}$ in scenario 2 and $16.7 \mathrm{Mgal} / \mathrm{d}$ in scenario 3. The well field was simulated as a single well and withdrawals were evenly

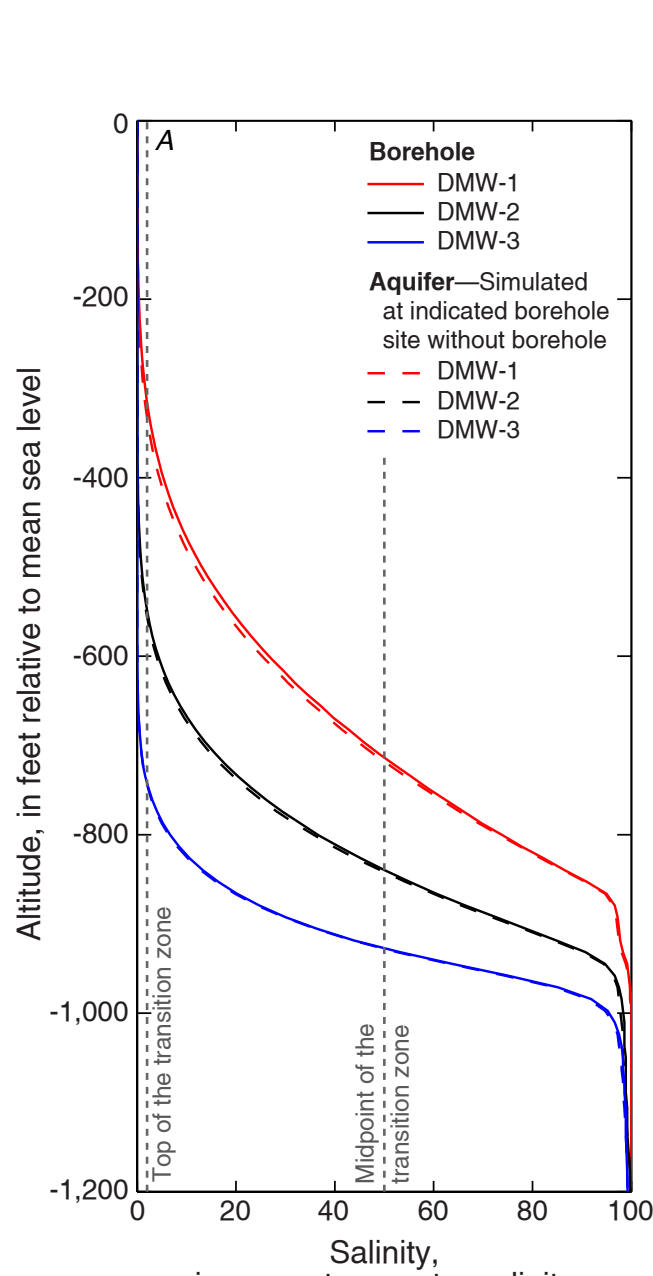

in percent seawater salinity

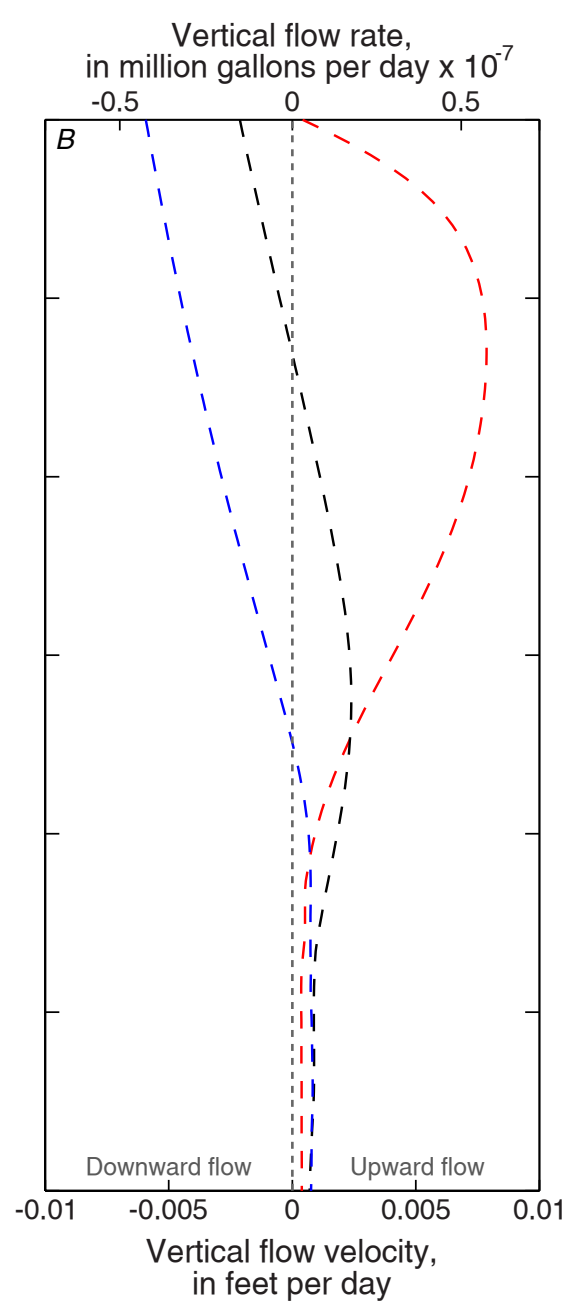

Vertical flow rate,

Figure 15. Model results of scenario 1a.-Regional aquifer flow with no additional withdrawals using the effective well hydraulic conductivity $\left(K_{\text {well }}\right)$ for deep monitor wells (DMWs). $A$, Simulated salinity profiles in DMWs and aquifer. $B$, Simulated vertical flow in the aquifer. $C$, Simulated vertical borehole flow. 

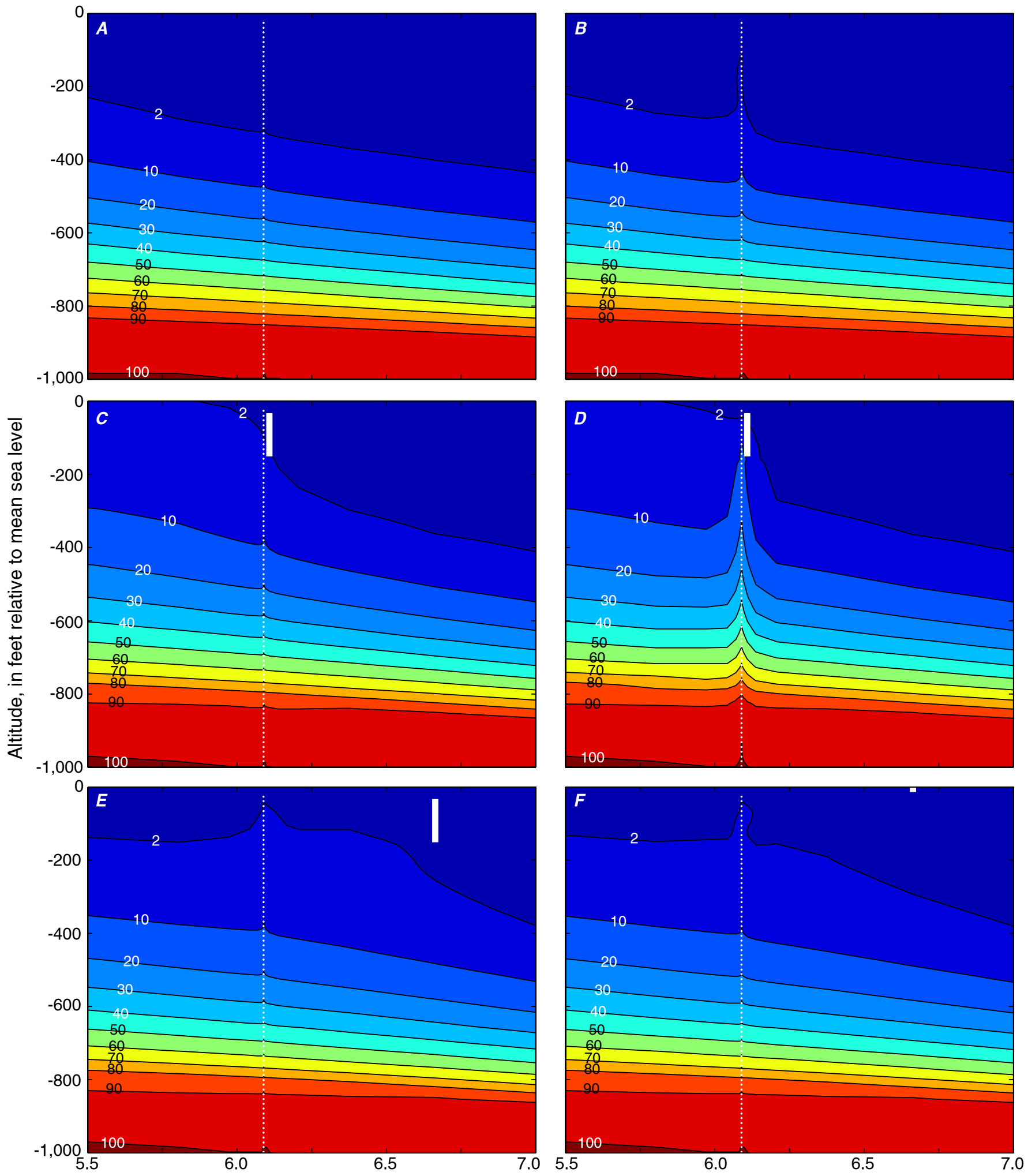

Horizontal distance, in miles from the coastline

Figure 16. Cross sections of simulated solute concentration in percent seawater salinity near DMW-1 (dotted line) in a homogeneous aquifer for selected model scenarios. The white bar represents the pumped interval. $A$, Scenario 1 a. $B$, Scenario 1b. C, Scenario 3a. D, Scenario 3b. E, Scenario 5. F, Scenario 6. 
distributed vertically over nine model cells between -33 and -151 $\mathrm{ft}$ relative to mean sea level. Both scenarios were run twice: once with the effective hydraulic conductivity of the well $K_{\text {well }}$ (scenarios $2 \mathrm{a}$ and $3 \mathrm{a}$ ) and once with $K_{t u r}$ (scenarios $2 \mathrm{~b}$ and $3 \mathrm{~b}$ ).

Scenario 2a.-Nearby groundwater withdrawals cause substantial borehole flow. In scenario $2 \mathrm{a}$, the 2 percent salinity depth in DMW-1, DMW-2, and DMW-3 is displaced 33, 7.3, and $2.0 \mathrm{ft}$, respectively (fig. 18A). Displacements of the 50 percent salinity depth and average salinity differences in all three DMWs are comparable to displacements and salinity differences in the base-case scenario 1a (table 3).

General borehole-flow directions and maximum velocities in DMW-2 and DMW-3 are similar to those from scenario 1a. Borehole flow in DMW-1 is downward in the upper part of the well and upward below $-80 \mathrm{ft}$, because it converges into the zone where water is withdrawn from the aquifer (fig. 18B). Flow velocities are between $-5,200$ and 9,100 ft/d in DMW-1 and the maximum borehole flow occurs near the bottom of the pumped interval at $-144 \mathrm{ft}$ at a rate of $0.07 \mathrm{Mgal} / \mathrm{d}$. The higher borehole
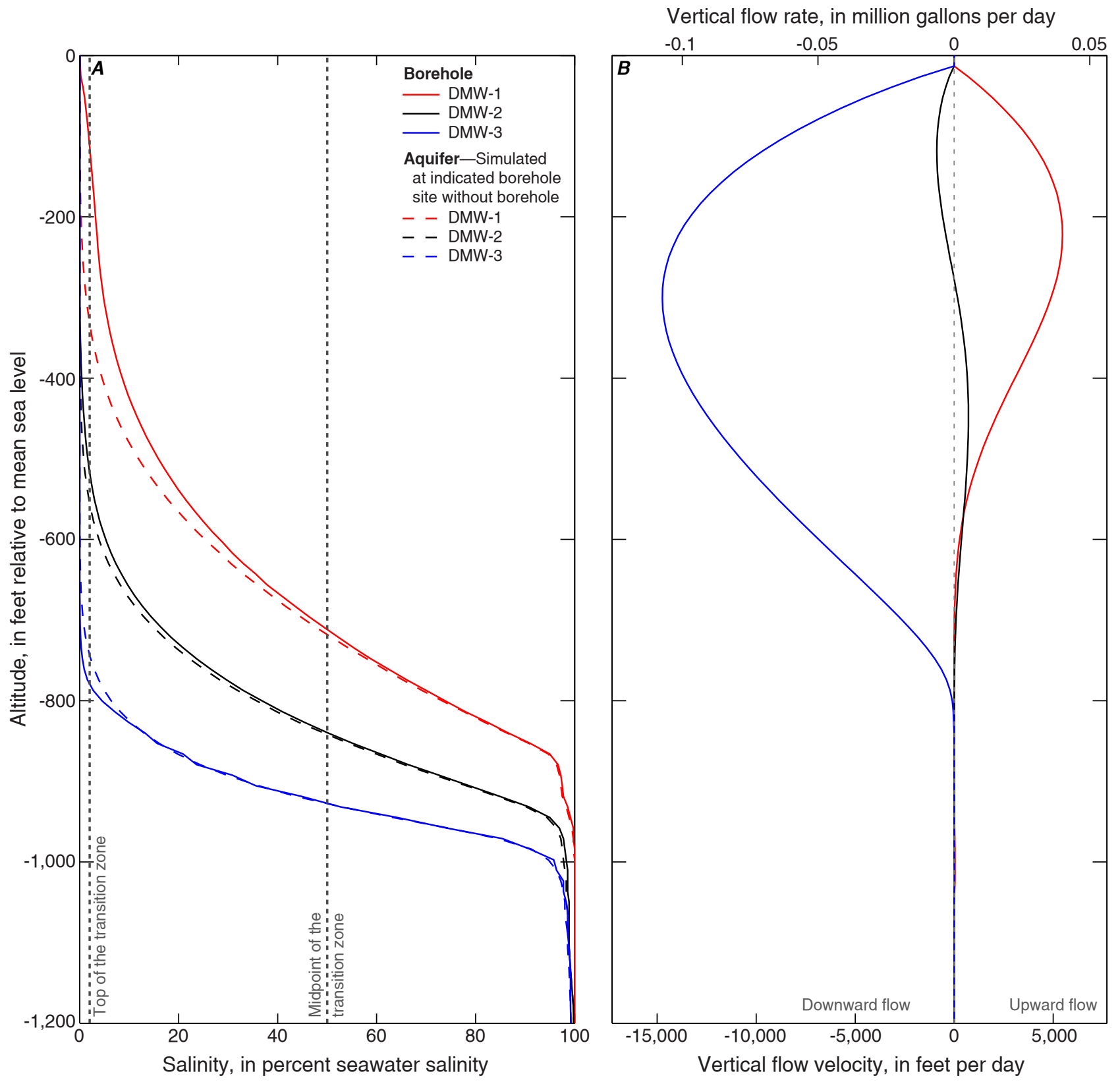

Figure 17. Model results of scenario 1b.--Regional aquifer flow with no additional withdrawals using the theoretical well hydraulic conductivity for turbulent flow $\left(K_{t u r}\right)$ for deep monitor wells (DMWs). $A$, Simulated salinity profiles. $B$, Simulated vertical borehole flow. 
flow compared to that in scenario 1a is induced by the nearby groundwater withdrawals.

Scenario $2 \boldsymbol{b}$. - Increasing the hydraulic conductivity of the boreholes to $K_{t u r}$ in scenario 2 b (withdrawals $100 \mathrm{ft}$ from DMW-1 at a rate of $4.3 \mathrm{Mgal} / \mathrm{d}$ ) increases the borehole flow and displacement of salinity inside DMW-1 relative to flow and displacement from scenario 2a. Borehole flow in DMW-1 is directed upward and the maximum flow velocity is 120,000 ft/d (fig. 19B). The 2 percent and 50 percent salinity depths in DMW-1 are displaced 231 and $19 \mathrm{ft}$, respectively (fig. 19A).
The average salinity difference between aquifer and borehole is 6.5 percent seawater salinity in DMW-1 (table 3). Salinity profiles and borehole-flow velocities in DMW-2 and DMW-3 are less affected. Due to the withdrawals, the maximum upward-flow velocity in DMW-2 increased to $1,100 \mathrm{ft} / \mathrm{d}$ from $720 \mathrm{ft} / \mathrm{d}$ in scenario $1 \mathrm{~b}$ (table 4).

Scenario 3a.-Withdrawals $100 \mathrm{ft}$ from DMW-1 were at a rate of $16.7 \mathrm{Mgal} / \mathrm{d}$ and the hydraulic conductivity of the wells was $K_{\text {well }}$ in scenario 3a (fig. 16C). Displacements of the 2 percent salinity depth in DMW-1, DMW-2, and DMW-3 are -8.8, 9.4, and


Figure 18. Model results of scenario 2a.-Additional withdrawal of 4.3 million gallons per day from a well 100 feet away from DMW-1 using the effective well hydraulic conductivity $\left(K_{\text {well }}\right)$ for deep monitor wells (DMWs). $A$, Simulated salinity profiles. $B$, Simulated vertical borehole flow. 
$3.5 \mathrm{ft}$, respectively (fig. 20A). The 2 percent salinity in DMW-1 is displaced downward because it is located within the converging flow zone induced by the nearby withdrawals. The effect of the converging flow zone is also apparent in the average salinity difference between aquifer and borehole. In this scenario, the average salinity difference in DMW-1 is 1.4 percent seawater salinity. Although this is larger than the average salinity difference of 0.85 percent salinity in scenario $2 a$, it reflects freshwater from the top of the aquifer entering the borehole above $-150 \mathrm{ft}$. In this upper zone, the salinity in the borehole is lower than the salinity of the aquifer, which decreases the overall salinity difference between aquifer and borehole.

The 50 percent salinity depth in DMW-1 is displaced $7.1 \mathrm{ft}$ (table 3). Model results indicate that borehole-flow velocities are between -20,000 and 35,000 ft/d in DMW-1 (fig. 20B) and are similar to velocities from scenarios 1a and $2 \mathrm{a}$ in DMW-2 and DMW-3 (table 4). The maximum flow simulated in DMW-1 is at a rate of $0.25 \mathrm{Mgal} / \mathrm{d}$, more than twice the observed flow. This indicates that simulations with a homogenous aquifer do not accurately reproduce measured borehole flow and salinities.
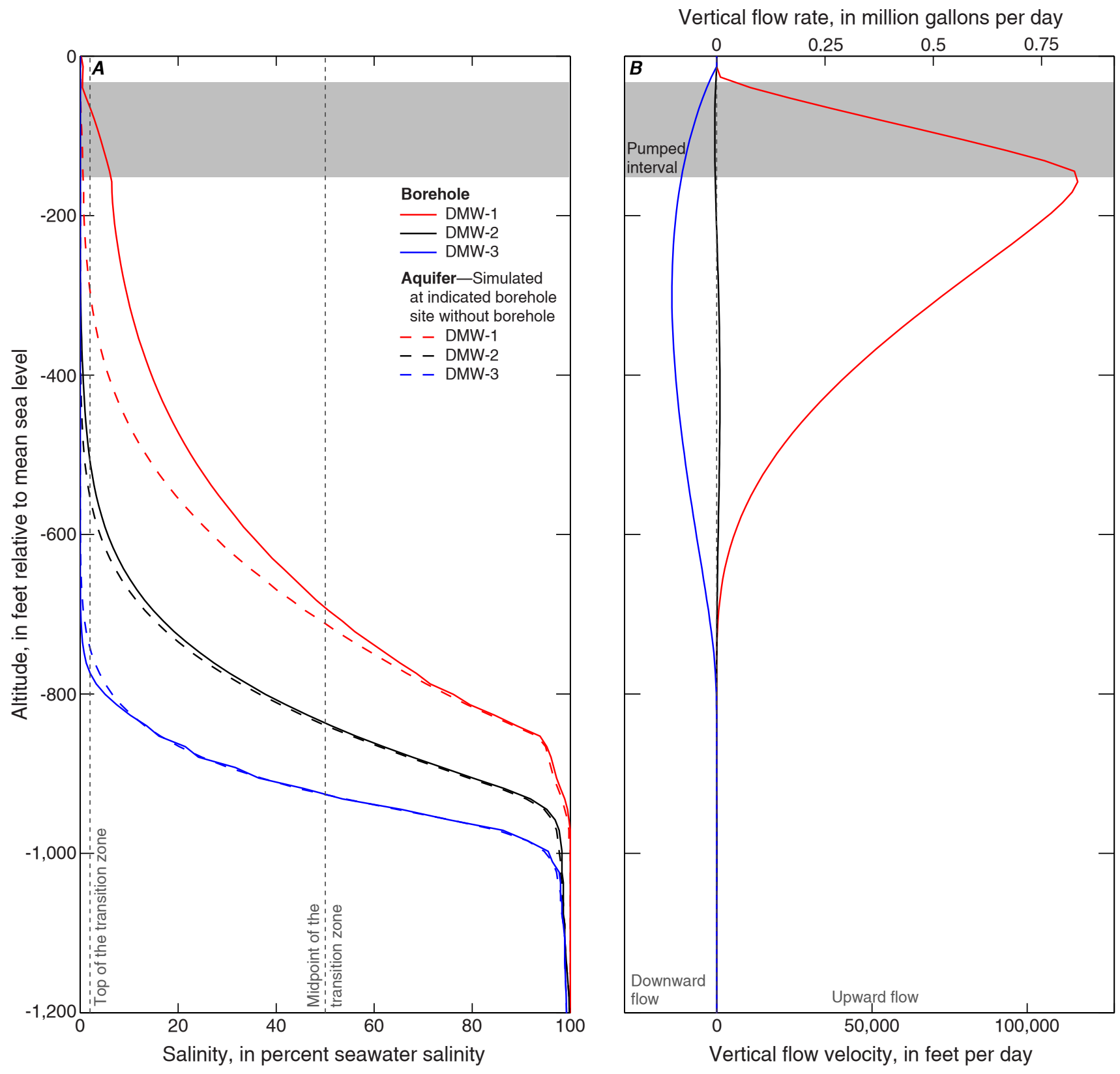

Figure 19. Model results of scenario $2 b$.-Additional withdrawal of 4.3 million gallons per day from a well 100 feet away from DMW-1 using the theoretical well hydraulic conductivity for turbulent flow $\left(K_{\text {tur }}\right)$ for deep monitor wells (DMWs). $A$, Simulated salinity profiles. $B$, Simulated vertical borehole flow. 
Increasing the groundwater-withdrawal rate nearly four times, from 4.3 Mgal/d (scenario 2a) to $16.7 \mathrm{Mgal} / \mathrm{d}$ (scenario 3a), $100 \mathrm{ft}$ away from DMW-1 causes borehole flow in DMW-1 to increase up to nearly four times. Thus, peak borehole flow in the simulated monitor wells is directly proportional to the pumping rate in the nearby production well.

Scenario $3 \boldsymbol{b}$.- Model results from scenario $3 \mathrm{~b}$ (withdrawals $100 \mathrm{ft}$ from DMW-1 at a rate of $16.7 \mathrm{Mgal} / \mathrm{d}$, using $K_{\text {tur }}$ for the borehole conductivity) indicate substantial upward borehole flow and upward displacement of salinity at DMW-1 (fig. 16D). The 2 percent and 50 percent salinity depths in DMW-1 are displaced 47 and $83 \mathrm{ft}$, respectively (fig. 21A). The average salinity difference between aquifer and borehole is 12.5 percent seawater salinity in DMW-1 and 1.1 percent salinity in DMW-2. Borehole flow in DMW-1 is directed upward throughout most of the well and the maximum flow velocity is $460,000 \mathrm{ft} / \mathrm{d}$, which corresponds to a peak flow rate of $3.3 \mathrm{Mgal} / \mathrm{d}$ (fig. $21 B$ ). However, observed maximum flow rates at Punanani DMW are less than $0.1 \mathrm{Mgal} / \mathrm{d}$ under these withdrawal conditions, an indication that $K_{\text {tur }}$ is overestimating borehole-flow rates by more than one order of magnitude.
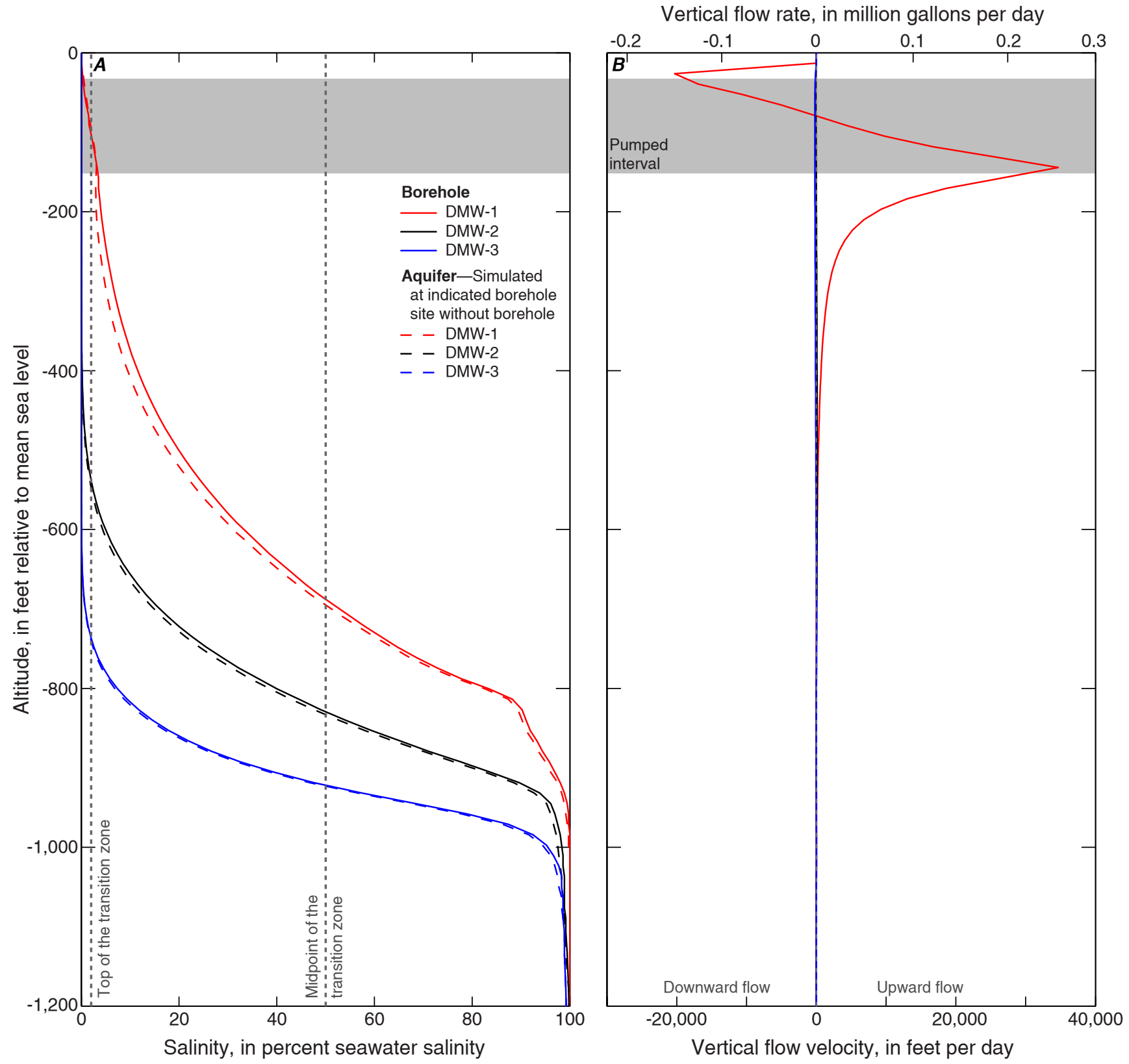

Figure 20. Model results of scenario 3a.-Additional withdrawal of 16.7 million gallons per day from a well 100 feet away from DMW-1 using the effective well hydraulic conductivity $\left(K_{\text {well }}\right)$ for deep monitor wells (DMWs). $A$, Simulated salinity profiles. $B$, Simulated vertical borehole flow. 
Salinity displacements in DMW-2 and DMW-3 are generally similar to those in scenario $2 \mathrm{~b}$, although the displacements of 2 percent and 50 percent salinity depths in DMW-2 are greater in scenario $3 \mathrm{~b}$ (table 3). Borehole-flow velocities in DMW-3 are similar to velocities in scenario $2 \mathrm{~b}$ (table 4 ), but in DMW-2 the maximum velocity in scenario $3 b(1,900 \mathrm{ft} / \mathrm{d})$ is nearly twice the maximum velocity in scenario $2 b(1,100 \mathrm{ft} / \mathrm{d})$. The high hydraulic conductivity of the well and the high withdrawal rate (from a production well $2.2 \mathrm{mi}$ away from DMW-2) cause borehole flow and displace the salinity profile in DMW-2.

\section{Withdrawal Far from Deep Monitor Wells}

Additional groundwater withdrawal in scenarios 4-6 was placed $0.6 \mathrm{mi}$ away from DMW-1, which is a typical distance between some production wellfields and DMWs in southern O'ahu. The distance between the simulated production well and DMW-2 is reduced from 2.2 to $1.6 \mathrm{mi}$. Groundwater withdrawals from the production well were $4.3 \mathrm{Mgal} / \mathrm{d}$ in scenario 4 and $16.7 \mathrm{Mgal} / \mathrm{d}$ in scenario 5 . Withdrawals were evenly distributed vertically over nine model cells between -33 and $-151 \mathrm{ft}$ relative to mean sea level.
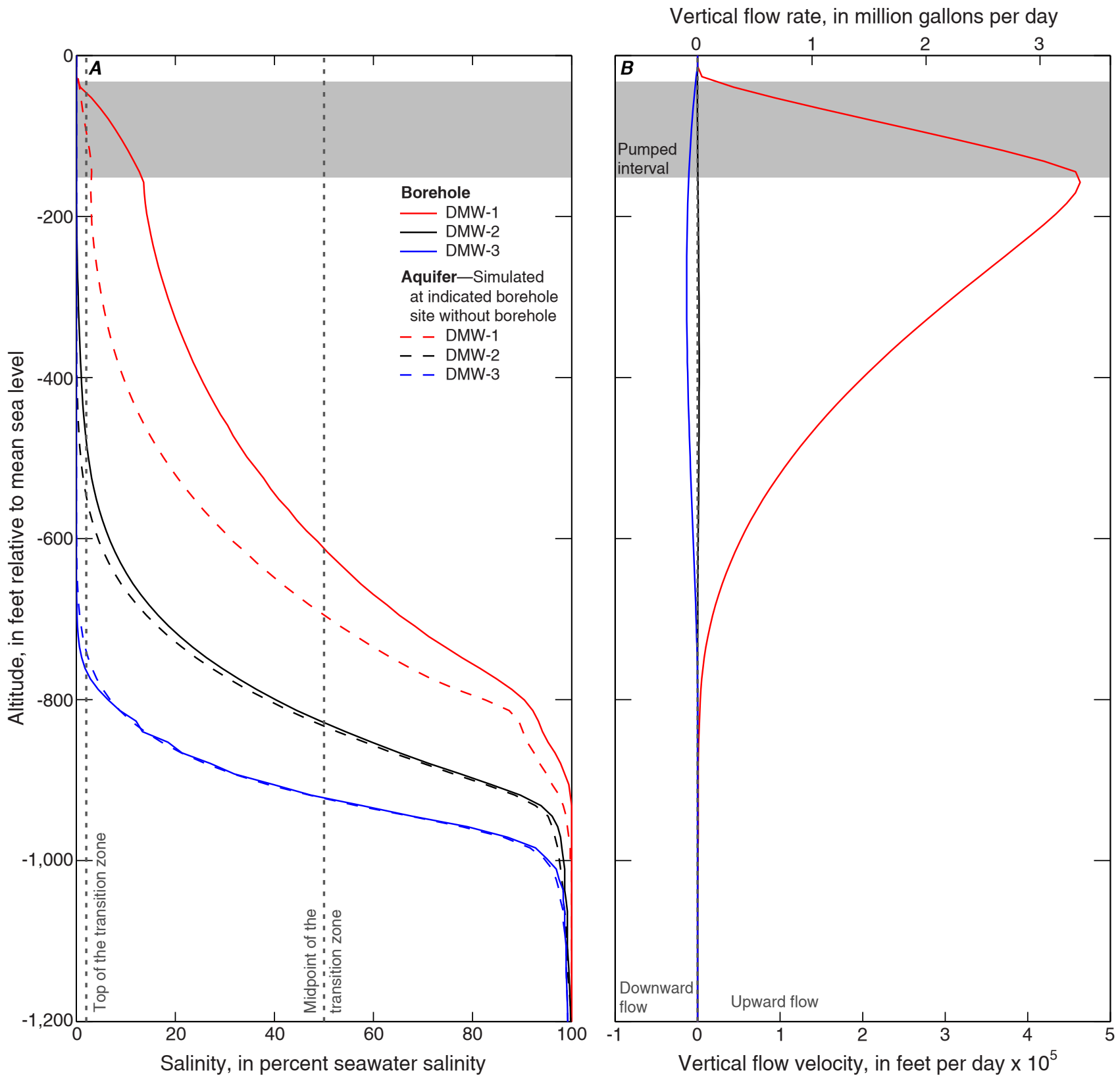

Figure 21. Model results of scenario 3b.-Additional withdrawal of 16.7 million gallons per day from a well 100 feet away from DMW-1 using the theoretical well hydraulic conductivity for turbulent flow $\left(K_{t u r}\right)$ for deep monitor wells (DMWs). $A$, Simulated salinity profiles. $B$, Simulated vertical borehole flow. 
Scenario 4.-Scenarios 4 and 2a differ only by the distances between the pumped well and the DMWs, and results from these scenarios are compared. Model results from scenario 4 indicate that the 2 percent salinity depths in DMW-1, DMW-2, and DMW-3 are displaced 25, 7.9, and $2.4 \mathrm{ft}$, respectively (fig. 22A). With the withdrawals farther away from DMW-1 in scenario 4 , the 2 percent salinity depth in DMW-1 is displaced upward 30 percent less than in scenario $2 \mathrm{a}$ (table 3 ). In contrast, the 2 percent and 50 percent salinity depths in DMW-2 are displaced slightly more, because the production well is closer to DMW-2 in scenario 4 relative to scenario $2 \mathrm{a}$. The average salinity differences between aquifer and borehole in all three DMWs are similar to average salinity differences in scenario $2 \mathrm{a}$. Borehole-flow velocities in DMW-2 and DMW-3 are comparable to those in scenario $2 \mathrm{a}$ (fig. 22B). However, maximum borehole-flow velocity in DMW-1 is 1.5 orders of magnitude lower than the maximum velocity from scenario $2 \mathrm{a}$ and only slightly higher than the simulated borehole-flow velocity without additional withdrawals in scenario 1a (table 4).
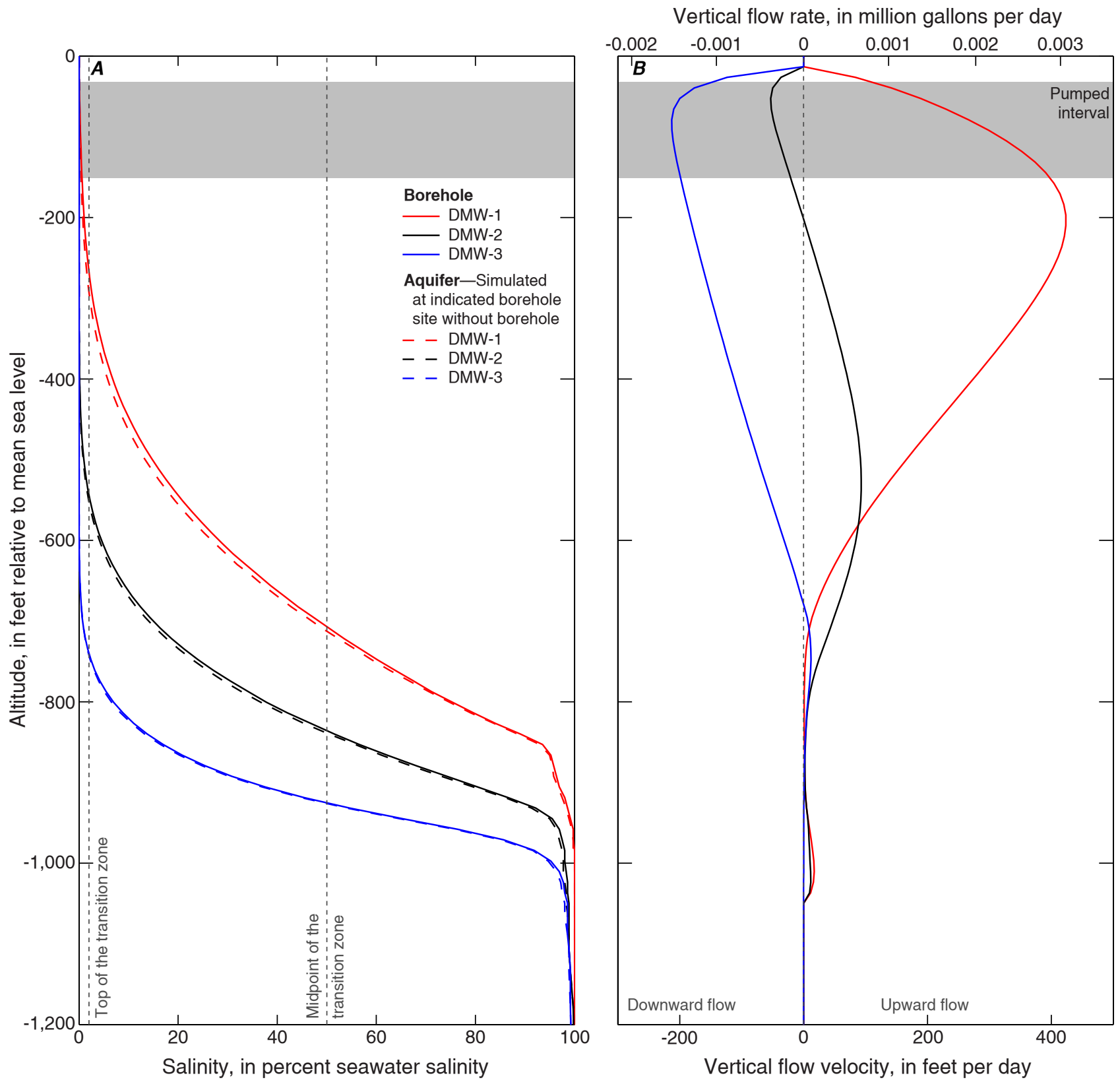

Figure 22. Model results of scenario 4.-Additional withdrawal of 4.3 million gallons per day from a well 3,000 feet away from DMW-1 using the effective well hydraulic conductivity $\left(K_{\text {well }}\right)$ for deep monitor wells (DMWs). $A$, Simulated salinity profiles. $B$, Simulated vertical borehole flow. 
Scenario 5.-The withdrawal rates in scenarios 5 and 3a are equal, and only the distances between the pumped well and the DMWs are different; thus, results from these scenarios are compared. In scenario 5 , the 2 percent salinity depth in DMW-1, DMW-2, and DMW-3 are displaced 114, 12 , and $4.4 \mathrm{ft}$, respectively (fig. 23A). The depth of the 2 percent salinity in DMW-1 is displaced more in scenario 5 than in scenario 3a (table 3), mainly because the converging flow zone from nearby withdrawals is now far enough away from DMW-1 to move the top of transition zone upwards only. Because the simulated salinity in the upper $150 \mathrm{ft}$ in DMW-1 is affected by the converging flow zone in scenario $3 \mathrm{a}$, the comparisons between scenarios 5 and $3 \mathrm{a}$ using either the 2 percent salinity depth or the average salinity difference should be interpreted accordingly.

The 50 percent salinity depth in scenario 5 is displaced 10 percent less in DMW-1 and is similar in DMW-2 relative to displacements in scenario 3a. Borehole-flow velocities in scenario 5 in DMW-2 and DMW-3 are comparable to velocities in scenario 3a. Maximum borehole-flow velocity in
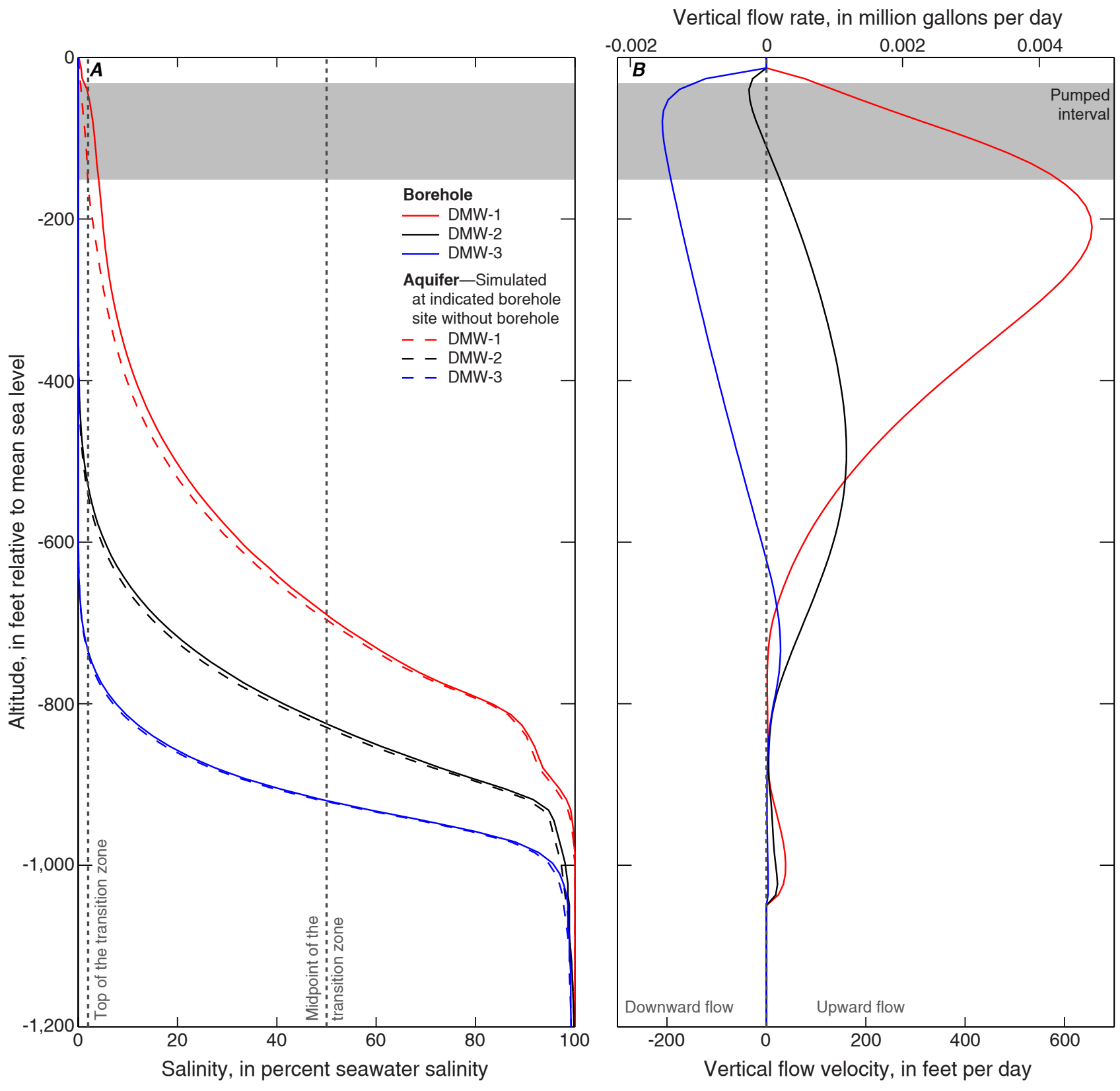

Figure 23. Model results of scenario 5.-Additional withdrawal of 16.7 million gallons per day from a well 3,000 feet away from DMW-1 using the effective well hydraulic conductivity $\left(K_{\text {well }}\right)$ for deep monitor wells (DMWs). $A$, Simulated salinity profiles. $B$, Simulated vertical borehole flow. 
DMW-1 from scenario $5(660 \mathrm{ft} / \mathrm{d})$ is three orders of magnitude lower than the maximum velocity from scenario $3 \mathrm{a}(35,000$ $\mathrm{ft} / \mathrm{d}$ ) because of the greater distance between the pumped well and DMW-1 in scenario 5 relative to scenario 3a. Overall, simulated groundwater withdrawals distant from DMW-1 are less influential on borehole flow and salinity displacements in DMW-1 than the withdrawals nearby (fig. 16E).

Scenario 6. - This scenario is included to simulate withdrawal from shafts. Shafts skim freshwater from near the water table through horizontal infiltration galleries. In the model, the shaft was placed $0.6 \mathrm{mi}$ away from DMW-1, stretching horizontally over $45 \mathrm{ft}$. The withdrawal at the shaft was at a rate of 16.7 Mgal/d, which was evenly distributed horizontally over six model cells at $-4 \mathrm{ft}$ relative to mean sea level.

Model results indicate that withdrawals from the shaft (scenario 6) have a similar effect on borehole salinity (fig. 16F) and borehole flow (fig. 24) as simulated withdrawal from vertical wells (scenario 5). However, the maximum borehole-flow
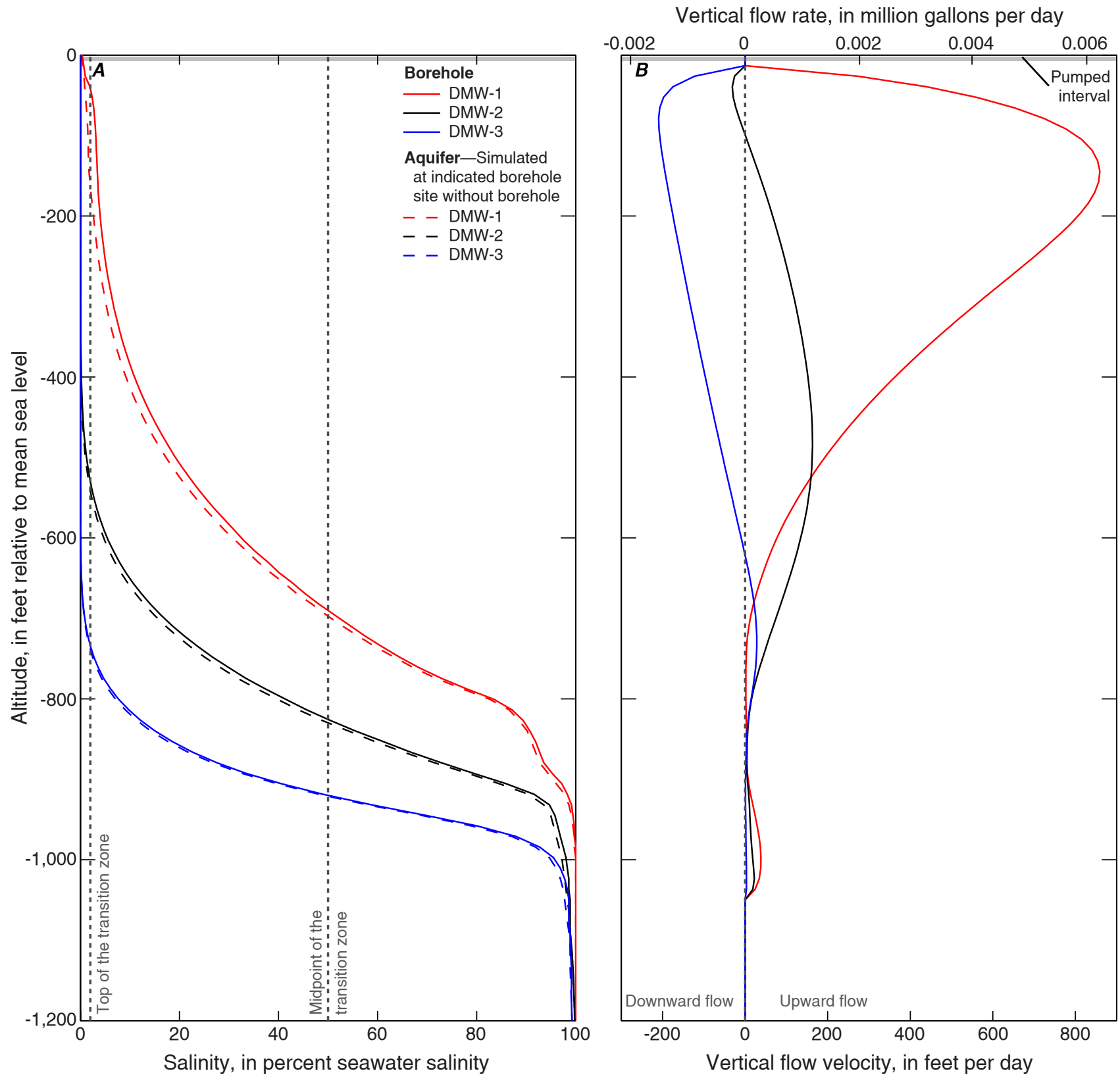

Figure 24. Model results of scenario 6.-Additional withdrawal of 16.7 million gallons per day from a shaft 3,000 feet away from DMW-1 using the effective well hydraulic conductivity $\left(K_{\text {well }}\right)$ for deep monitor wells (DMWs). $A$, Simulated salinity profiles. $B$, Simulated vertical borehole flow. 
velocity in DMW-1 is slightly greater in scenario $6(860 \mathrm{ft} / \mathrm{d})$ relative to the maximum velocity in scenario $5(660 \mathrm{ft} / \mathrm{d})$, and, therefore, the displacement of the 2 percent salinity depth in
DMW-1 is slightly greater ( $123 \mathrm{ft}$ in scenario 6 compared to $114 \mathrm{ft}$ in scenario 5). Other salinity displacements and borehole flows are similar to those in scenario 5 (tables 3 and 4).

Table 3. Summary of the borehole-flow model results in the form of displacements of the 2 and 50 percent salinity depths in the borehole relative to the aquifer, and average salinity difference between aquifer and borehole from the midpoint upwards. Displacement is determined from the difference in altitude of specified fluid salinity within the borehole and altitude of same salinity in an equivalent aquifer without a borehole.

[Positive values indicate upward displacement or salinity increase and negative values indicate downward displacement or salinity decrease; shading indicates scenarios using the well hydraulic conductivity for turbulent flow]

\begin{tabular}{|c|c|c|c|c|c|c|c|c|c|}
\hline \multirow[t]{2}{*}{ Scenario } & \multicolumn{3}{|c|}{$\begin{array}{c}\text { Displacement } \\
\text { of } 2 \text { percent } \\
\text { salinity depth, in feet }\end{array}$} & \multicolumn{3}{|c|}{$\begin{array}{l}\text { Displacement } \\
\text { of } 50 \text { percent } \\
\text { salinity depth, in feet }\end{array}$} & \multicolumn{3}{|c|}{$\begin{array}{l}\text { Average salinity difference } \\
\text { from midpoint upwards, in } \\
\text { percent seawater salinity }\end{array}$} \\
\hline & DMW-1 & DMW-2 & DMW-3 & DMW-1 & DMW-2 & DMW-3 & DMW-1 & DMW-2 & DMW-3 \\
\hline $1 a$ & 17. & 6.6 & 1.3 & 4.4 & 2.2 & .7 & .65 & .27 & .06 \\
\hline $1 b$ & 220. & 38. & -36 & 6.4 & 2.2 & .2 & 2.9 & .60 & -.21 \\
\hline $2 a$ & 33. & 7.3 & 2.0 & 4.6 & 3.1 & .6 & .85 & .29 & .08 \\
\hline $2 b$ & 231. & 46. & -31. & 19. & 3.0 & .2 & 6.5 & .70 & -.17 \\
\hline $3 a$ & -8.8 & 9.4 & 3.5 & 7.1 & 4.4 & .9 & 1.4 & .39 & .12 \\
\hline $3 b$ & 47. & 68. & -24 & 83. & 4.4 & .6 & 13. & 1.1 & -.07 \\
\hline 4 & 25. & 7.9 & 2.4 & 5.8 & 3.2 & .8 & .8 & .31 & .09 \\
\hline 5 & 114. & 12. & 4.4 & 6.4 & 4.5 & 1.2 & 1.7 & .45 & .15 \\
\hline 6 & 123. & 12. & 4.4 & 7.2 & 4.3 & 1.2 & 1.6 & .45 & .14 \\
\hline 7 & 44. & 16. & -1.6 & 4.2 & 1.7 & .4 & 2.3 & .35 & .00 \\
\hline 8 & 42. & 16. & -1.7 & 7.6 & 2.3 & .3 & 2.4 & .37 & .00 \\
\hline
\end{tabular}

Table 4. Summary of the borehole-flow model results in the form of minimum and maximum borehole-flow velocities.

[Min, minimum; Max, maximum; positive values indicate upward and negative values indicate downward flow direction; shading indicates scenarios using the well hydraulic conductivity for turbulent flow]

\begin{tabular}{crrrrrr}
\hline & \multicolumn{3}{c}{ Vertical borehole-flow velocity, in feet per day } \\
\cline { 2 - 7 } Scenario & \multicolumn{2}{c}{ DMW-1 } & \multicolumn{2}{c}{ DMW-2 } & \multicolumn{2}{c}{ DMW-3 } \\
\cline { 2 - 7 } & \multicolumn{1}{c}{ Min } & \multicolumn{1}{c}{ Max } & \multicolumn{1}{c}{ Min } & Max & \multicolumn{1}{c}{ Min } & Max \\
\hline $\mathbf{1 a}$ & 0 & 310 & -61 & 71 & -210 & 7.5 \\
$\mathbf{1 b}$ & 0 & 5,500 & -880 & 720 & $-15,000$ & 3.8 \\
$\mathbf{2 a}$ & $-5,200$ & 9,100 & -57 & 85 & -210 & 11. \\
$\mathbf{2 b}$ & 0 & 120,000 & -600 & 1,100 & $-14,000$ & 9.1 \\
$\mathbf{3 a}$ & $-20,000$ & 35,000 & -49 & 120 & -210 & 23. \\
$\mathbf{3 b}$ & -1 & 460,000 & -160 & 1,900 & $-13,000$ & 6.5 \\
$\mathbf{4}$ & 0 & 420 & -53 & 93 & -210 & 12. \\
$\mathbf{5}$ & 0 & 660 & -35 & 160 & -210 & 28. \\
$\mathbf{6}$ & 0 & 860 & -31 & 160 & -210 & 28. \\
$\mathbf{7}$ & $-5,000$ & 2,900 & -48 & 120 & -170 & .9 \\
$\mathbf{8}$ & $-22,000$ & 11,000 & -71 & 130 & -170 & .7 \\
\hline
\end{tabular}




\section{Heterogeneity}

Scenarios 7 and 8.- -Selected horizontal low-permeability layers were introduced in the basalt aquifer cutting through the open interval of DMW-1 and DMW-2 in scenarios 7 and 8. The goal was to reproduce steps in salinity profiles and borehole flow observed in Kaimukī DMW (fig. 4) and Punanani DMW (Rotzoll, 2010). Heterogeneous basalt layers extend horizontally from $9.7 \mathrm{mi}$ inland to the contact with the caprock and from the east boundary to $0.5 \mathrm{mi}$ westward to simulate 1-mi-wide lava flows.

Layer thickness and aquifer properties (fig. 25) were estimated with a trial-and-error calibration approach until reasonable matches between observed and simulated salinity profiles in Punanani DMW and borehole flow in Kaimukī DMW and Punanani DMW were achieved. The measured vertical salinity step in Kaimukī DMW was not used for the calibration, because it is less pronounced. The ratio of horizontal to



Figure 25. Hydraulic conductivity distribution for the heterogeneous basalt aquifer used in scenarios 7 and 8 . vertical hydraulic conductivity was 200 for the largest horizontal hydraulic-conductivity value $(1,350 \mathrm{ft} / \mathrm{d}), 100$ for the value of $330 \mathrm{ft} / \mathrm{d}$, and 10 for the two smaller values (33 and $3 \mathrm{ft} / \mathrm{d}$ ). All other aquifer-property values were identical to the homogeneous aquifer representation (table 1).

Additional groundwater withdrawal was placed $100 \mathrm{ft}$ away from DMW-1. Groundwater withdrawal from a well (3.8 Mgal/d in scenario 7, $16.7 \mathrm{Mgal} / \mathrm{d}$ in scenario 8) was evenly distributed vertically over nine model cells between -33 and $-151 \mathrm{ft}$ relative to mean sea level. The simulated withdrawal depth is similar to open intervals of production wells at Punanani and Kaimukī well fields.

In the model, local withdrawal near a DMW alone cannot produce large vertical steps in a homogeneous aquifer. Zones of low hydraulic conductivity, caused by massive lava flows, sealing of cracks after drilling, or clogging of pore space around the well, can create a step in the measured salinity profile. Compared to the simulated salinity profiles from the homogeneous aquifers (scenarios $2 \mathrm{a}$ and $3 \mathrm{a}$ ), the simulated salinity profiles in DMW-1 from scenarios 7 and 8 include a vertical step, which is consistent with measured salinity in Punanani DMW (fig. 26A).

Model results of scenario 7 indicate that the 2 percent and 50 percent salinity depth in DMW-1 are displaced 44 and $4.2 \mathrm{ft}$, respectively. The average salinity difference between aquifer and borehole is 2.3 percent seawater salinity in DMW-1 and 0.35 percent salinity in DMW-2. Salinity in all three DMWs is almost identical in scenario 8 (table 3), except that the 50 percent salinity is displaced substantially more in DMW-1 and DMW-2 due to the larger withdrawal rate.

Borehole-flow velocities in scenario 7 are between $-5,000$ and 2,900 ft/d in DMW-1, between -48 and $120 \mathrm{ft} / \mathrm{d}$ in DMW-2, and between -170 and $0.9 \mathrm{ft} / \mathrm{d}$ in DMW-3 (fig. 26B). Relative to simulated velocities in scenario 7, in scenario 8, velocities are similar in DMW-2 and DMW-3 but about four times larger in DMW-1, due to the increased withdrawals. Borehole-flow velocities in DMW-1 in scenario 8 are between $-22,000$ and 11,000 ft/d. Peak borehole-flow rates are 0.02 and $0.08 \mathrm{Mgal} / \mathrm{d}$ in scenarios 7 and 8 , respectively. Although the measured borehole-flow velocities are variable, the simulated velocity profiles generally match the measured vertical velocity profiles under both pumping rates. However, the inclusion of DMWs and local-scale heterogeneities in regional models is not feasible, because computational limitations with an extensive grid-cell size exist and detailed information about heterogeneity in the subsurface is generally lacking.

\section{Borehole-Flow Effects on Aquifer Salinity}

The effect of borehole flow on salinity near DMWs is investigated by comparing the average salinity difference from the midpoint upwards (fig. 14B) between simulations of scenarios with and without simulated boreholes as a function of distance from DMW-1. The concern is that brackish water 
may reach shallower zones of the aquifer through the DMW, which may affect drinking-water resources. Note that interpretation of salinity differences for scenario 3 a must consider the effects of the converging flow zone induced by large withdrawals $100 \mathrm{ft}$ from DMW-1.

From the DMW towards the coast, the salinity difference in the aquifer, caused by the presence of DMWs, diminishes to less than 0.3 percent seawater salinity $1,000 \mathrm{ft}$ away from DMW-1 in most scenarios (fig. 27A). This is important because some production wells in the Pearl Harbor aquifer are located within that distance to a DMW. The Punanani well field, for example, is located within $100 \mathrm{ft}$ of the DMW and groundwater has been withdrawn for the past $40 \mathrm{yr}$. However, measured water salinity in the production wells is still below the threshold of drinking-water standards (Rotzoll, 2010).

In the inland direction, salinity differences in the aquifer are less than 0.3 percent seawater salinity $250 \mathrm{ft}$ away from DMW-1 in all scenarios (fig. 27B). This is consistent with observations that water samples from wells downgradient of a DMW have higher salinities than samples from wells that are located upgradient

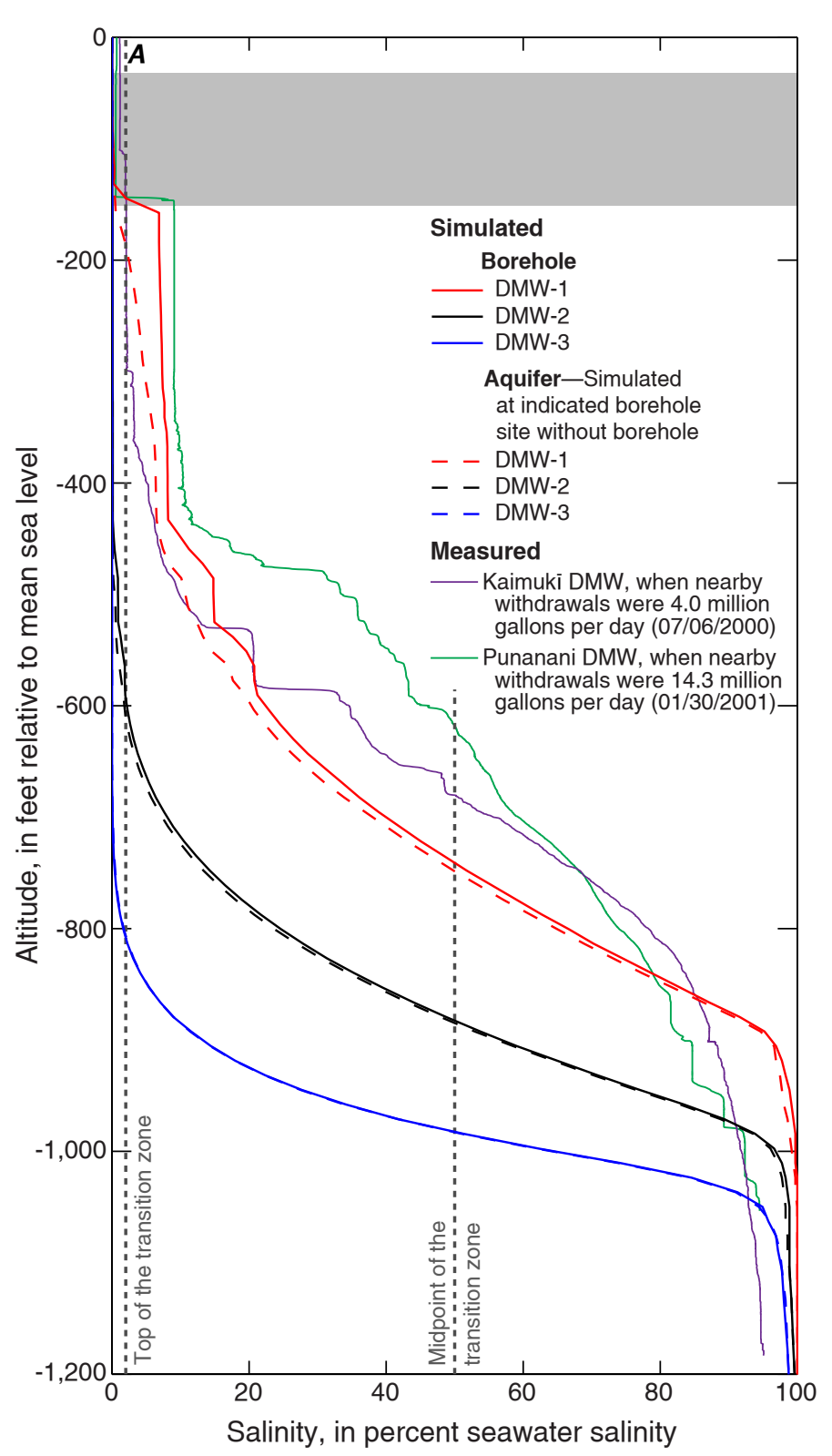

Vertical flow rate, in million gallons per day

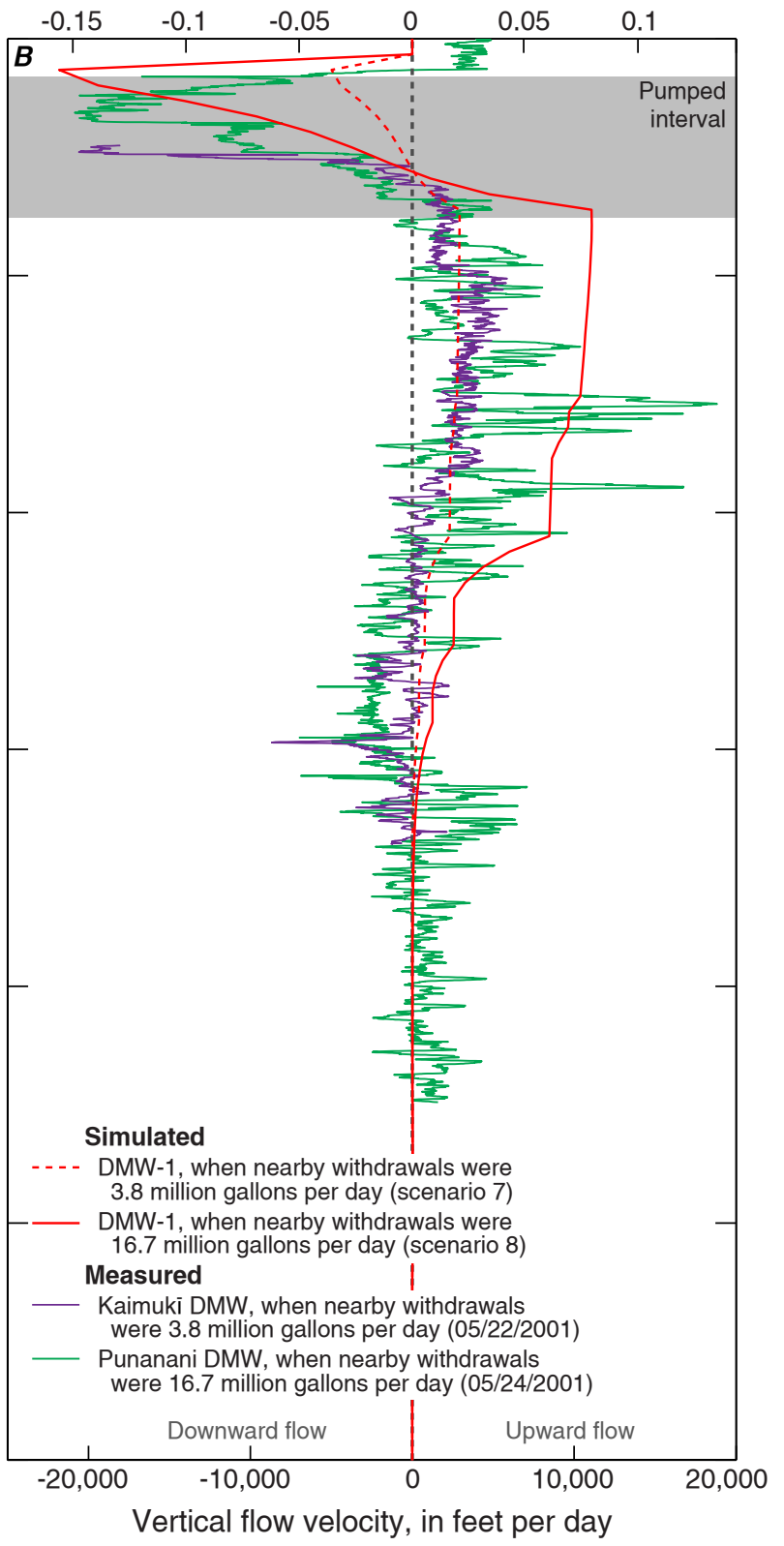

Figure 26. Model results of scenarios 7 and 8.-Additional withdrawal of 3.8 and 16.7 million gallons per day from a well 100 feet away from DMW-1 using the effective well hydraulic conductivity $\left(K_{\text {well }}\right)$ for deep monitor wells (DMWs) in a heterogeneous aquifer. $A$, Observed and simulated salinity profiles for scenario 8 . $B$, Observed and simulated vertical borehole flow. 


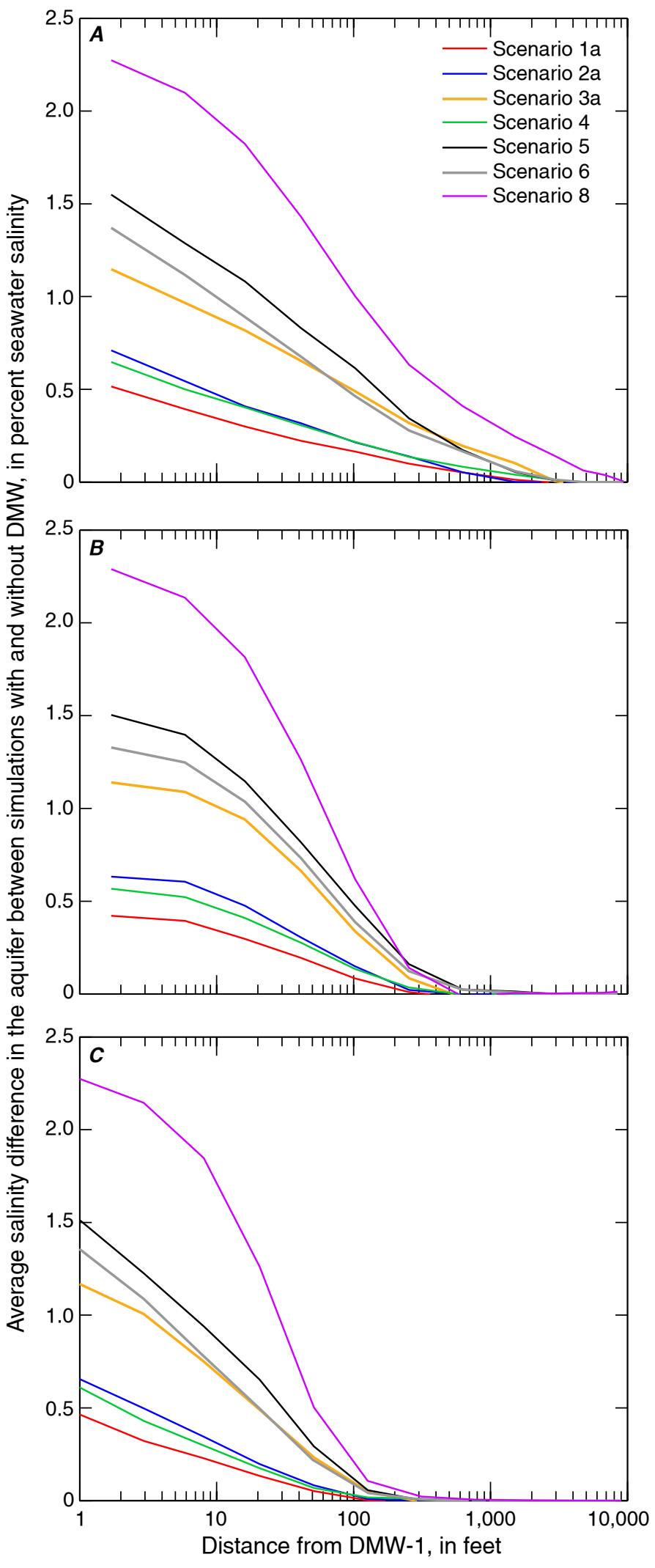

Figure 27. Average salinity difference between simulations with and without deep monitor well (DMW) relative to distance from $\mathrm{DMW}-1$. $A$, From $\mathrm{DMW}-1$ towards the coast. $B$, From DMW-1 away from the coast. $C$, From DMW-1 parallel to the coast.
(Rotzoll, 2010). Parallel to the coast, the salinity in the aquifer diminishes to less than 0.3 percent levels $100 \mathrm{ft}$ away from the DMW (fig. 27C). The shorter reach is due to the lower horizontal hydraulic conductivity and lower dispersivity perpendicular to the principal groundwater-flow direction.

\section{Model Limitations}

The borehole-flow model presented here simulates water levels, salinity, and borehole flow for a three-dimensional representation of the Pearl Harbor aquifer but may not accurately predict either the water level at an individual well or the salinity distribution with depth in that well. The model is mainly conceptual in nature, built to understand the dynamics of uncased monitor wells penetrating into the saltwater, to understand the magnitude of the effect of borehole flow on the location of the transition zone measured in the well, and to develop an understanding of the factors that control and influence that effect. The model is therefore not intended to specifically simulate actual conditions in the Pearl Harbor aquifer. The salinity distribution with depth in a well may be controlled by local heterogeneities in the aquifer that are not represented in the homogeneous or the heterogeneous model scenarios selected for this study. The model has several other limitations for predictive purposes, discussed below, because of the various assumptions used and possible uncertainties in input data.

The two-dimensional representation of the Pearl Harbor aquifer extrapolated to a three-dimensional box model is not an exact representation of the Pearl Harbor aquifer. The model is mainly based on published average values for aquifer hydraulic characteristics, recharge, groundwater withdrawal, and spring discharge and is therefore not a calibrated transient regional model. Recharge and regional groundwater withdrawals were simulated as steady fluxes that do not include seasonal or interdecadal variations. Spatial heterogeneities in hydrogeology in the east-west direction were not accounted for in the model.

Groundwater withdrawals in the Pearl Harbor area are treated as reduced areal recharge to maintain symmetry for the steady-state base case. While this approach preserves the overall water budget, it does not accurately represent the groundwaterflow directions that would exist if the withdrawals were simulated in their actual locations. However, only a regional model could resolve this limitation and that was beyond the scope of the study.

Further, uncertainty exists in the estimated distribution of hydrologic properties. The estimated layering and aquifer properties in the heterogeneous aquifer scenarios provide an acceptable match between simulated and measured salinity profiles and borehole flow but represent only one of many plausible combinations of layering and aquifer properties.

Potential uncertainties exist in available measured salinity profiles and borehole flow. Calibration of simulated salinity profiles was based on observed salinity profiles. Borehole flow affects salinity profiles in many wells in southern O'ahu. Uncertainties related to the salinity in the aquifer may affect the calibration of the model. Thus, an exact match of freshwater-lens thickness with observed salinity profiles was 
not a goal of the study. Uncertainty regarding the hydraulic conductivity of the well also exists and is addressed by testing a plausible range of values.

Borehole flow in the model follows a linear head-loss function. Therefore, only nonturbulent flow is simulated, although observed flow velocities indicate some Reynolds numbers in the turbulent flow regime. Modeling efforts can be improved when modeling packages capable of simulating turbulent flow, such as the Multi-Node Well package (Halford and Hanson, 2002) or the Conduit Flow Process package (Shoemaker and others, 2008), are supported for densitydependent flow in SEAWAT V4.

Confidence in model results can be improved by addressing the limitations described in this section. In particular, improved measurements of borehole flow under different withdrawal conditions, incorporation of threedimensional distribution of model parameters (regional model), and enhanced model functionality of simulating turbulent flow in monitor wells likely will lead to better model reliability. Despite these limitations, the model developed for this study does an acceptable job providing information needed to evaluate the effects of borehole flow on measured salinity profiles from DMWs.

\section{Summary}

The Pearl Harbor aquifer in southern O'ahu is one of the most important sources of freshwater in Hawai' $i$. Freshwater availability is commonly assessed using salinity profiles measured in uncased deep monitor wells (DMWs). Vertical flow in these wells can cause the measured salinity to differ from salinity in the adjacent aquifer. In fact, substantial borehole flow and displacement of salinity in DMWs over several hundred feet has been observed in the Pearl Harbor aquifer. The objective of this study was to provide information on how effectively measured vertical salinity profiles from DMWs represent conditions in the adjacent aquifer or an equivalent aquifer without a DMW.

A numerical modeling approach using SEAWAT V4 and incorporating the hydraulic characteristics and recharge data representative of the Pearl Harbor aquifer, was used to evaluate the effects of borehole flow on measured salinity profiles from DMWs. A two-dimensional vertical cross section aligned along the principal groundwater-flow direction in the Pearl Harbor aquifer was laterally expanded to a threedimensional rectangular box model. Hydraulic properties and boundary conditions were uniform in the direction parallel to the coast, except for the boreholes and additional groundwater withdrawals. Borehole flow caused by vertical hydraulic gradients associated with both the natural regional flow system and with local groundwater withdrawals near to and far from DMWs was simulated.

Model results indicate that borehole-flow velocities caused by the natural groundwater-flow system without local groundwater withdrawals is five orders of magnitude greater than the vertical flow velocities in the homogeneous aquifer. The contrast is consistent with the larger vertical hydraulic conductivity in the well compared to the aquifer. Directions of borehole flow are consistent with the regional flow system: downward flow in inland recharge areas and upward flow in coastal discharge areas. Displacement of salinity inside the wells does not exceed $17 \mathrm{ft}$ for an effective hydraulic conductivity of the well determined from measured flow velocities $\left(K_{\text {well }}\right)$. However, using the theoretical well hydraulic conductivity for turbulent flow $\left(K_{t u r}\right)$, borehole-flow velocities under natural groundwater-flow conditions increase more than an order of magnitude, and upward displacement of the 2 percent salinity depth exceeds $220 \mathrm{ft}$ in the coastal DMW-1. Using $K_{\text {well }}$, the average salinity difference from the midpoint (50 percent salinity depth) upwards is 0.65 percent seawater salinity in DMW-1, which indicates that salinity in the DMWs is largely unaffected by borehole flow from the regional groundwater flow field. Commonly, a 1 percent error in salinity is acceptable for numerical modeling studies.

Borehole flow and movement of salinity in the well that is caused by local groundwater withdrawals are greater than flow and displacements under natural flow conditions. Simulated groundwater withdrawals of $4.3 \mathrm{Mgal} / \mathrm{d} 100 \mathrm{ft}$ from a DMW causes thirty times more borehole flow than borehole flow induced by the regional flow field. The 2 percent borehole salinity is displaced $33 \mathrm{ft}$ or $231 \mathrm{ft}$, depending on the assumed hydraulic conductivity of the well. Peak borehole flow caused by local groundwater withdrawals near DMWs is directly proportional to the pumping rate in the nearby production well. The upward displacement of the 50 percent salinity depth in DMW-1 increases from 4.6 to $7.1 \mathrm{ft}$ (using $K_{\text {well }}$ ) and from 19 to $83 \mathrm{ft}$ (using $K_{t u r}$ ). The average salinity difference increases from 0.85 to 11.4 percent seawater salinity (using $K_{\text {well }}$ ) and from 6.5 to 12.5 percent salinity (using $K_{\text {tur }}$ ) in DMW-1.

Simulated groundwater withdrawals 3,000 ft away from DMW-1 are less influential on borehole flow and salinity than the withdrawals nearby. For simulated withdrawal wells 3,000 ft from DMW-1, increasing the withdrawal rate from 4.3 to $16.7 \mathrm{Mgal} / \mathrm{d}$ causes borehole flow in DMW-1 to increase by only 50 percent. However, due to the closer location of withdrawals to DMW-2, borehole-flow velocities in DMW-2 increased by 70 percent with the higher withdrawal rates. Displacement of the 2 percent salinity depth in DMW-1 increases from 25 to $114 \mathrm{ft}$, and the 50 percent salinity depth shifts from 5.8 to $6.4 \mathrm{ft}$ with the higher withdrawal rate.

Effects of groundwater withdrawals from a horizontal shaft and withdrawals from a vertical well in a homogeneous aquifer were generally similar, except that borehole-flow velocities in DMW-1 were greater and upward displacement of the 2 percent salinity depth was slightly greater (123 instead of $114 \mathrm{ft}$ ) for the scenario that simulated withdrawal from a shaft.

Generally, the 50 percent salinity depths are less affected by borehole flow than the 2 percent salinity depths. Hence, measured salinity profiles are useful for calibration of regional numerical models despite borehole-flow effects. 
Commonly, a 1 percent error in salinity is acceptable in numerical modeling studies.

Local withdrawals near a DMW alone cannot produce the large vertical steps observed in salinity profiles in southern $\mathrm{O}^{\text {' }}$ ahu when the entire well is in contact with a homogeneous aquifer. Over the length of such a step, the salinity remains constant because mixing of water in the borehole with water from the aquifer is limited. Thus, water inside the well can be more brackish than water in the aquifer under upward borehole-flow conditions. Thick zones of low hydraulic conductivity rock may limit exchange of water between aquifer and well and lead to a vertical step in the salinity profile. The heterogeneous basalt aquifer simulated in this study is one of many plausible aquifer representations. Nevertheless, simulated salinity profiles include observed vertical steps and simulated borehole flow is consistent with measured borehole flow from DMWs in southern $\mathrm{O}^{\text {‘ahu. }}$ Due to limitations of model grid-cell size and lack of detailed information about heterogeneity in the subsurface, the inclusion of local-scale heterogeneities in regional models is not warranted.

Model results indicate that, with all other factors being equal, larger withdrawal rates, closer withdrawal locations, higher hydraulic conductivity of the well, and lower vertical aquifer hydraulic conductivity result in greater borehole flow and displacement of salinity in the well. Heterogeneity in the aquifer around the monitor well is necessary to produce vertical steps in salinity profiles in the model. Reliability in the model results can be improved by better boreholeflow measurements under different withdrawal conditions, incorporation of three-dimensional distribution of model parameters to extend the two-dimensional to a regional model, and enhanced representation of DMWs in the model.

\section{References Cited}

Badon Ghyben, W., 1889, Nota in verband met de voorgenomen putboring nabij Amsterdam: Tijdschrift van het Koninklijk Instituut van Ingenieurs, p. 8-22.

Chen, C., and Jiao, J.J., 1999, Numerical simulation of pumping tests in multilayer wells with non-darcian flow in the wellbore: Ground Water, v. 37, no. 3, p. 465-474.

Clesceri, L.S., Greenberg, A.E., and Eaton, A.D., 1998, Standard methods for the examination of water and wastewater (20th ed.): Washington, D.C., American Public Health Association, $1220 \mathrm{p}$.

Doell, R.R., and Dalrymple, G.B., 1973, Potassium-argon ages and paleomagnetism of the Waianae and Koolau Volcanic Series, Oahu, Hawaii: Geological Society of America Bulletin, v. 84 , no. 4, p. 1217-1242.

Elci, A., Gregory, P.F., and Molz, F.J., 2003, Detrimental effects of natural head gradients on chemical and water level measurements in observation wells; identification and control: Journal of Hydrology, v. 281, nos. 1-2, p. 70-81.
Elci, A., Molz, F.J., III, and Waldrop, W.R., 2001, Implications of observed and simulated ambient flow in monitoring wells: Ground Water, v. 39, no. 6, p. 853-862.

Garcia, C.A., Halford, K.J., and Laczniak, R.J., 2010, Interpretation of flow logs from Nevada Test Site boreholes to estimate hydraulic conductivity using numerical simulations constrained by single-well aquifer tests: U.S. Geological Survey Scientific Investigations Report 2010-5004, 28 p. (Also available at http://pubs.usgs.gov/sir/2010/5004/.)

Geankoplis, C.J., 1993, Transport processes and unit operations (3rd ed.): Englewood Cliffs, New Jersey, Prentice-Hall, 921 p.

Giambelluca, T.W., Nullet, M.A., and Schroeder, T.A., 1986, Rainfall atlas of Hawai' $i$ : State of Hawai' $i$, Department of Land and Natural Resources, Division of Water and Land Development Report R76, 267 p.

Gingerich, S.B., 2008, Ground-water availability in the Wailuku area, Maui, Hawai' 'i: U.S. Geological Survey Scientific Investigations Report 2008-5236, 95 p. (Also available at http:// pubs.usgs.gov/sir/2008/5236/.)

Gingerich, S.B., and Oki, D.S., 2000, Ground water in Hawaii: U.S. Geological Survey Fact Sheet 126-00, 6 p. (Also available at http://pubs.usgs.gov/fs/2000/126.)

Gingerich, S.B., and Voss, C.I., 2005, Three-dimensional variabledensity flow simulation of a coastal aquifer in southern Oahu, Hawaii, USA: Hydrogeology Journal, v. 13, no. 2, p. 436-450.

Halford, K.J., 2000, Simulation and interpretation of borehole flowmeter results under laminar and turbulent flow conditions, in Proceedings of the Seventh International Symposium on Logging for Minerals and Geotechnical Applications, Golden, Colorado, October 24-26, 2000: Houston, Tex., Society of Petrophysicists and Well Log Analysts, p. 157-168.

Halford, K.J., and Hanson, R.T., 2002, User guide for the drawdown-limited, Multi-Node Well (MNW) package for the U.S. Geological Survey's modular three-dimensional finitedifference ground-water flow model, Versions MODFLOW-96 and MODFLOW-2000: U.S. Geological Survey Open-File Report 02-293, 32 p. (Also available at http://pubs.er.usgs.gov/ publication/ofr02293.)

Harbaugh, A.W., Banta, E.R., Hill, M.C., and McDonald, M.G., 2000, MODFLOW-2000, the U.S. Geological Survey modular ground-water model-User guide to modularization concepts and the ground-water flow process: U.S. Geological Survey Open-File Report 2000-92, 121 p. (Also available at http:// pubs.er.usgs.gov/publication/ofr200092.)

Hawaii Gap Analysis Program, 2005, Hawai 'i Gap Analysis Program, Oahu island land cover: Hawai 'i Biodiversity and Mapping Program, Center for Conservation Research and Training, University of Hawai 'i, accessed March 14, 2011, at http://hbmp.hawaii.edu/higap/downloads/.

Herzberg, A., 1901, Die Wasserversorgung einiger Nordseebāder: Journal fūr Gasbeleuchtung und Wasserversorgung, v. 44, no. 44, 45, p. 815-819, 842-844.

Hunt, C.D., Jr., 1996, Geohydrology of the island of Oahu, Hawaii: U.S. Geological Survey Professional Paper 1412-B, 55 p. (Also available at http://pubs.er.usgs.gov/publication/ pp1412B.) 
Izuka, S.K., and Gingerich, S.B., 1998, Estimation of the depth to the fresh-water/salt-water interface from vertical head gradients in wells in coastal and island aquifers: Hydrogeology Journal, v. 6, no. 3, p. 365-373.

Konikow, L.F., and Hornberger, G.Z., 2006, Modeling effects of multinode wells on solute transport: Ground Water, v. 44, no. 5, p. 648-660.

Lacombe, S., Sudicky, E.A., Frape, S.K., and Unger, A.J.A., 1995, Influence of leaky boreholes on cross-formational groundwater flow and contaminant transport: Water Resources Research, v. 31, no. 8, p. 1871-1882.

Langevin, C.D., Thorne, D.T., Jr., Dausman, A.M., Sukop, M.C., and Guo, W., 2007, SEAWAT Version 4; a computer program for simulation of multi-species solute and heat transport: U.S. Geological Survey Techniques and Methods Book 6, Chapter A22, 39 p. (Also available at http://pubs.usgs.gov/tm/tm6a22/.)

Lau, L.S., and Mink, J.F., 2006, Hydrology of the Hawaiian Islands: Honolulu, University of Hawai' i Press, 274 p.

Liu, C.C.K., 2006, Analytical groundwater flow and transport modeling for the estimation of sustainable yield of Pearl Harbor Aquifer: University of Hawai ‘i, Water Resources Research Center Project Report PR-2006-06, 53 p., accessed August 11, 2011, at http://scholarspace.manoa.hawaii.edu/ handle/10125/4074.

Liu, C.C.K., 2007, RAM2 modeling and determination of sustainable yields of Hawaii basal aquifers: University of Hawai' i, Water Resources Research Center Project Report PR-2008-06, 81 p., accessed August 11, 2011, at http:// hawaii.gov/dlnr/cwrm/publishedreports/PR200806.pdf.

Macdonald, G.A., Abbott, A.T., and Peterson, F.L., 1983, Volcanoes in the sea: The geology of Hawaii (2nd ed.): Honolulu, Hawai ‘i, University of Hawai 'i Press, 517 p.

Meyer, C.F., Kleinecke, D.C., Todd, D.K., and Ewing, L.E., 1974, Mathematical modeling of freshwater aquifers having saltwater bottoms: General Electric Co., TEMPO, Center for Advanced Studies, final technical completion report GE74TMP-43, $176 \mathrm{p}$.

Meyer, W., and Souza, W.R., 1995, Factors that control the amount of water that can be diverted to wells in a high-level aquifer, in Hermann, R., Back, W., Sidle, R.C., and Johnson, A.I., eds., Water resources and environmental hazards; emphasis on hydrologic and cultural insight in the Pacific Rim: Honolulu, Hawai 'i, Proceedings of the American Water Resources Association Annual Summer Symposium, June 25-28, p. 207-216.

Mink, J.F., 1981, Determination of sustainable yields in basal aquifer, in Fujimura, F.N., and Chang, W.B.C., eds., Groundwater in Hawaii-a century of progress: University of Hawai 'i, Water Resources Research Center, p. 101-116.

Nichols, W.D., Shade, P.J., and Hunt, C.D., 1996, Summary of the Oahu, Hawaii, regional aquifer-system analysis: U.S. Geological Survey Professional Paper 1412-A, 71 p. (Also available at http://pubs.er.usgs.gov/publication/pp1412A.)
Oki, D.S., 1998, Geohydrology of the central Oahu, Hawaii, ground-water flow system and numerical simulation of the effects of additional pumping: U.S. Geological Survey WaterResources Investigations Report 97-4276, 132 p. (Also available at http://pubs.er.usgs.gov/publication/wri974276.)

Oki, D.S., 2005, Numerical simulation of the effects of lowpermeability valley-fill barriers and the redistribution of groundwater withdrawals in the Pearl Harbor area, Oahu, Hawaii: U.S. Geological Survey Scientific Investigations Report 2005-5253, 111 p. (Also available at http://pubs.usgs.gov/sir/2005/5253/.)

Oki, D.S., Souza, W.R., Bolke, E.L., and Bauer, G.R., 1998, Numerical analysis of the hydrogeologic controls in a layered coastal aquifer system, Oahu, Hawaii, USA: Hydrogeology Journal, v. 6, no. 2, p. 243-263.

Paillet, F.L., and Hess, A.E., 1995, Geophysical log data from basalt aquifers near Waipahu on the Island of Oahu and Pahoa on the island of Hawaii, Hawaii: U.S. Geological Survey OpenFile Report 95-383, 62 p. (Also available at http://pubs.er.usgs. gov/publication/ofr95383.)

Paillet, F.L., Williams, J.H., Oki, D.S., and Knutson, K.D., 2002, Comparison of formation and fluid-column logs in a heterogeneous basalt aquifer: Ground Water, v. 40, no. 6, p. 577-585.

Reilly, T.E., Franke, O.L., and Bennett, G.D., 1989, Bias in groundwater samples caused by wellbore flow: Journal of Hydraulic Engineering, v. 115, no. 2, p. 270-276.

Rotzoll, K., 2007, Hydraulic parameter estimation using aquifer tests, specific capacity, ocean tides, and wave setup for Hawai' $i$ aquifers: Honolulu, University of Hawai 'i, Ph.D. dissertation, 160 p. accessed August 11, 2011, at http://www.soest.hawaii. edu/GG/resources/theses/Rotzoll_2007_Dissertation_hi.pdf.

Rotzoll, K., 2010, Effects of groundwater withdrawal on borehole flow and salinity measured in deep monitor wells in Hawai' $i-$ implications for groundwater management: U.S. Geological Survey Scientific Investigations Report 2010-5058, 42 p. (Also available at http://pubs.usgs.gov/sir/2010/5058/.)

Rotzoll, K., and El-Kadi, A.I., 2007, Numerical ground-water flow simulation for Red Hill fuel storage facilities, NAVFAC Pacific, Oahu, Hawaii: University of Hawai' $i$, Water Resources Research Center, prepared for TEC Inc., 74 p.

Rotzoll, K., and El-Kadi, A.I., 2008a, Estimating hydraulic conductivity from specific capacity for Hawaii aquifers, USA: Hydrogeology Journal, v. 16, no. 5, p. 969-979.

Rotzoll, K., and El-Kadi, A.I., 2008b, Estimating hydraulic properties of coastal aquifers using wave setup: Journal of Hydrology, v. 353, nos. 1-2, p. 201-213.

Rotzoll, K., El-Kadi, A.I., and Gingerich, S.B., 2007, Estimating hydraulic properties of volcanic aquifers using constant-rate and variable-rate aquifer tests: Journal of the American Water Resources Association, v. 43, no. 2, p. 334-345.

Rotzoll, K., El-Kadi, A.I., and Gingerich, S.B., 2008, Analysis of an unconfined aquifer subject to asynchronous dual-tide propagation: Ground Water, v. 46, no. 2, p. 239-250. 
Rotzoll, K., Oki, D.S., and El-Kadi, A.I., 2010, Changes of freshwater-lens thickness in basaltic islands aquifers overlain by thick coastal sediments: Hydrogeology Journal, v. 18, no. 6, p. 1425-1436.

Shade, P.J., and Nichols, W.D., 1996, Water budget and effects of land-use changes on ground-water recharge, Oahu, Hawaii: U.S. Geological Survey Professional Paper 1412-C, 38 p. (Also available at http://pubs.er.usgs.gov/publication/pp1412C.)

Shalev, E., Lazar, A., Wollman, S., Kington, S., Yechieli, Y., and Gvirtzman, H., 2009, Biased monitoring of fresh water-salt water mixing zone in coastal aquifers: Ground Water, v. 47, no. 1, p. 49-56.

Shoemaker, W.B., Kuniansky, E.L., Birk, S., Bauer, S., and Swain, E.D., 2008, Documentation of a Conduit Flow Process (CFP) for MODFLOW-2005: U.S. Geological Survey Techniques and Methods 6-A24, 50 p. (Also available at http://pubs.usgs.gov/ tm/tm6a24/.)

Souza, W.R., and Voss, C.I., 1987, Analysis of an anisotropic coastal aquifer system using variable-density flow and solute transport simulation: Journal of Hydrology, v. 92, no. 1, p. 17-41.

Stearns, H.T., 1939, Geologic map and guide of the island of Oahu, Hawaii: Hawai'i Division of Hydrography Bulletin 2, 75 p.

Stearns, H.T., and Vaksvik, K.N., 1935, Geology and ground-water resources of the island of Oahu, Hawaii: Hawai' $i$ Division of Hydrography Bulletin 1, 479 p.

Takasaki, K.J., and Mink, J.F., 1985, Evaluation of major dikeimpounded ground-water reservoirs, island of Oahu: U.S. Geological Survey Water-Supply Paper 2217, 77 p. (Also available at http://pubs.er.usgs.gov/publication/wsp2217.)

Tóth, J., 1962, A theory of groundwater motion in small drainage basins in central Alberta, Canada: Journal of Geophysical Research, v. 67, no. 11, p. 4375-4387.

U.S. Environmental Protection Agency, 2011, Secondary drinking water regulations; guidance for nuisance chemicals: U.S. Environmental Protection Agency, accessed August 11, 2011, at http://water.epa.gov/drink/contaminants/secondarystandards. cfm.

Visher, F.N., and Mink, J.F., 1964, Ground-water resources in southern Oahu, Hawaii: U.S. Geological Survey Water Supply Paper 1778, 133 p. (Also available at http://pubs.er.usgs.gov/ publication/wsp1778.)

Voss, C.I., and Souza, W.R., 1987, Variable density flow and solute transport simulation of regional aquifers containing a narrow freshwater-saltwater transition zone: Water Resources Research, v. 23 , no. 10 , p. 1851-1866.

Wentworth, C.K., 1938, Geology and ground-water resources of the Palolo-Waialae district: Honolulu Board of Water Supply, 274 p.

Whittier, R.B., Rotzoll, K., Dhal, S., El-Kadi, A.I., Ray, C., and Chang, D., 2010, Groundwater source assessment program for the State of Hawaii, USA; methodology and example application: Hydrogeology Journal, v. 18, no. 3, p. 711-723.
Williams, J.A., and Soroos, R.L., 1973, Evaluation of methods of pumping test analysis for application to Hawaiian aquifers: University of Hawaii, Water Resources Research Center Technical Report 70, 159 p.

Winston, 2000, Graphical user interface for MODFLOW, Version 4: U.S. Geological Survey Open-File Report 00-315, 27 p. (Also available at http://pubs.er.usgs.gov/publication/ofr00315.)

Wolfe, E.W., and Morris, J., 1996, Geologic map of the Island of Hawaii: U.S. Geological Survey Miscellaneous Investigations Series Map I-2524-A, scale 1:100,000. (Also available at http:// pubs.er.usgs.gov/publication/i2524A.)

Zheng, C., and Wang, P.P., 1999, MT3DMS-A modular threedimensional multispecies transport model for simulation of advection, dispersion, and chemical reactions of contaminants in groundwater systems; documentation and user's guide: U.S. Army Corps of Engineers Contract Report SERDP-99-1, 221 p.

Zinn, B.A., and Konikow, L.F., 2007, Effects of intraborehole flow on groundwater age distribution: Hydrogeology Journal, v. 15, no. 4, p. 633-643. 
